\title{
PRODUÇÃO E VALOR NUTRITIVO DOS CAPINS MARANDU E MOMBAÇA EM DIVERSAS ÉPOCAS DE VEDAÇÃO E USO
}

\author{
MOEMA FERREIRA BUENO \\ Zootecnista
}

Orientador: Prof. Dr. Herbert Barbosa de Mattos

\begin{abstract}
Dissertação apresentada à Escola Superior de Agricultura "Luiz de Queiroz", Universidade de São Paulo, para obtenção do título de Mestre em Agronomia, Área de Concentração: Ciência Animal e Pastagens.
\end{abstract}

\footnotetext{
PIRACICABA

Estado de São Paulo - Brasil

Outubro - 1999
} 
Dados Internacionais de Catalogação na Publicação (CIP)

DIVISÃo DE BIBLIOTECA E DOCUMENTAÇĀO - Campus "Luiz de Queiroz"/USP

Bueno, Moema Ferreira.

Produçāo e valor nutritivo dos capins marandu e mombaça em diversas épocas de vedação e uso / Moema Ferreira Bueno. -- Piracicaba, 1999.

67 p. : il.

Dissertaçāo (mestrado) - Escola Superior de Agricultura Luiz de Queiroz, 1999.

Bibliografia.

1. Digestabilidade in vitro 2. Graminea forrageira tropical 3. Lignina 4. Materia seca 5. Pastagem 6. Valor nutritivo 7. Variedade I. Título

CDD 633.2

Termitta a copia total ou parcial deste documento, desde que citada a fonte-O Autor" 
Aos meus pais

José e Alice,

\section{OFEREÇO}

Às sobrinhas Mariana e Luiza, DEDICO 
"Se não houve frutos, houveram as flores Se não houve flores, houveram as folhas Se não houveram as folhas, Houve a intenção da semente plantada" (Henfil) 


\section{AGRADECIMENTOS}

A Deus por eu ter chegado até aqui.

À ESALQ-USP, por receber-me e conceder-me a oportunidade para a realização de mais uma etapa acadêmica.

Ao Prof. Dr. Herbert Barbosa de Mattos, pela fácil convivência, amizade e orientação.

Aos Profs. Drs. da banca examinadora pelas críticas construtivas.

Ao Grupo Manah, pela concessão da Fazenda Mundo Novo, para a condução do experimento à campo.

Aos Profs. Drs. Sila Cameiro da Silva e Francisco Monteiro pelas informações e críticas construtivas e à Profa Dra. Sônia Maria de Stéfano Piedade pelo auxilio nas análises estatísticas.

Aos meus pais José e Alice pelo que me ensinaram e aos meus tios Luzia, Maria Rosa e Benedicto e a minha avó Maria, pelo apoio e carinho.

Ao Leandro Alves da Silva Figueiredo pelo auxilio sempre presente e pela confecção deste e a minha irmã Jussara pela nossa amizade.

A todos os meus amigos e principalmente à Cristina, Michelle, Moizéis, Mônica Sartori, Maurício e Carlos Giaveno, pela amizade e ajuda na realização deste.

A todos os professores do Curso de Pós-Graduação em Ciência Animal e Pastagens, pelos conhecimentos transmitidos.

Às responsáveis técnicas Lourdes e Nivanda do laboratório de Nutrição Mineral de Plantas do Departamento de Química da ESALQ e ao técnico Carlos César do laboratório de Bromatologia do Departamento de Produção Animal da ESALQ, pelo auxilio na execução das análises laboratoriais.

Ao CAPES, peia boisa de estudos concedida.

Á FAPESP, pelo financiamento do projeto.

A todos que colaboraram de alguma forma. 


\section{SUMÁRIO}

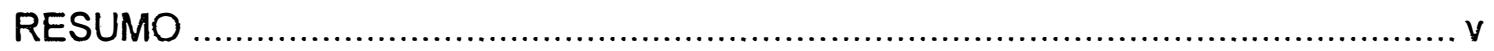

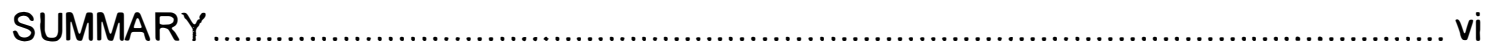

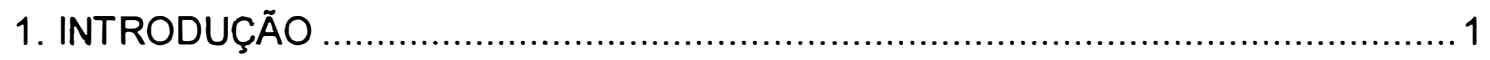

2. REVISÃO DE LITERATURA ............................................................... 2

2.1 Espécies forrageiras utilizadas: $B$. brizantha e $P$. maximum ...............................2

2.2. Vedação-aspectos de manejo .................................................................... 3

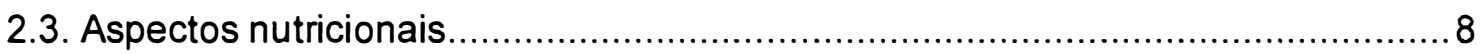

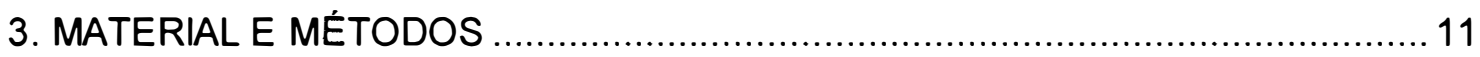

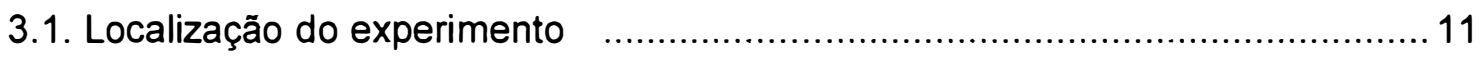

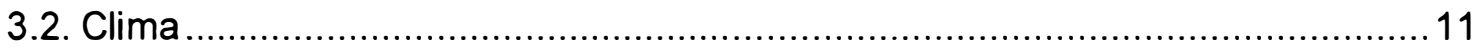

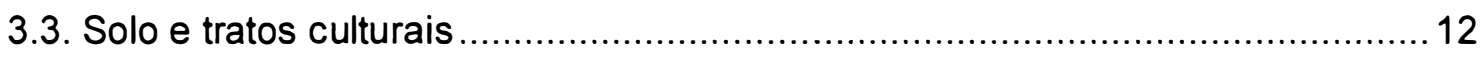

3.4. Delineamento experimental e análises laboratoriais ................................... 13

3.5. Análises estatísticas ......................................................................... 14

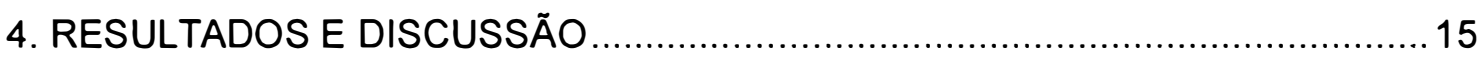

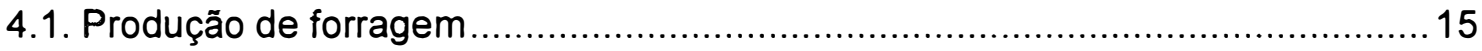

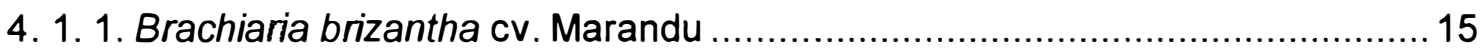

4. 1. 2. Panicum maximum cv. Mombaça .......................................................... 19

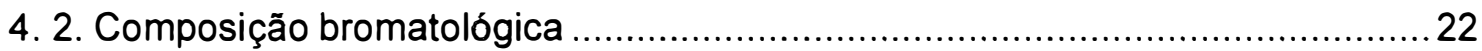

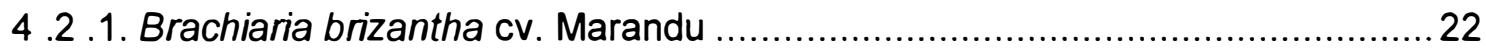

4. 2. 2. Panicum maximum cv. Mombaça ............................................................ 34

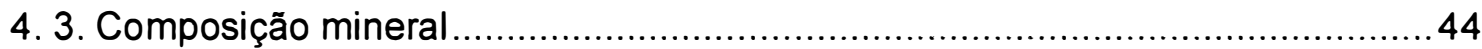

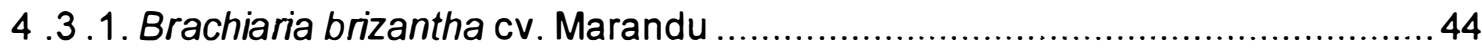

4. 3. 2. Panicum maximum cv. Mombaça ........................................................ 50

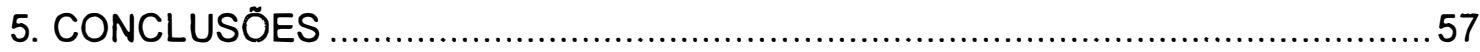

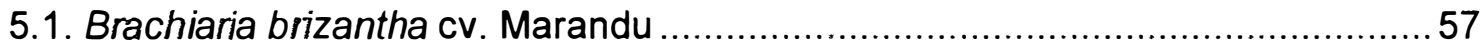

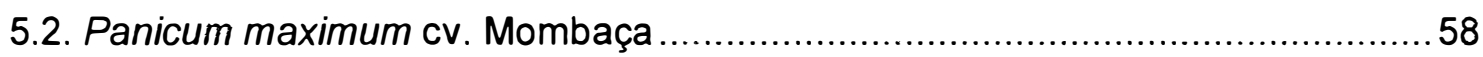

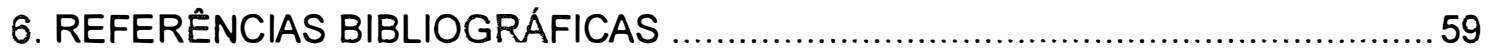




\title{
PRODUÇÃO E VALOR NUTRITIVO DOS CAPINS MARANDU E MOMBAÇA EM DIVERSAS ÉPOCAS DE VEDAÇÃO E USO
}

\author{
Autora: MOEMA FERREIRA BUENO \\ Orientador: HERBERT BARBOSA DE MATTOS
}

\section{RESUMO}

O trabalho foi realizado na Fazenda Mundo Novo, no municipio de Brotas - SP $\left(22^{\circ} 10^{\prime} \mathrm{S}\right.$ de latitude e $48^{\circ} 02^{\prime} \mathrm{W}$ de longitude), utilizando-se duas forrageiras tropicais, Brachiaria brizantha cv. Marandu e Panicum maximum cv. Mombaça, cultivadas em áreas distintas, onde estudou-se os efeitos de três épocas de vedação (10 de março, 24 de março e 07 de abril) que representaram as parcelas principais e quatro de épocas de uso ( 27 de junho, 25 de julho, 25 de agosto e 22 de setembro) que representaram as subparcelas, na produção e valor nutritivo, num latossolo vermelho amarelo. O delineamento experimental foi em blocos completos ao acaso num arranjo em parcelas subdivididas, com quatro repetições. A forragem foi avaliada quanto à produção de MS, teores de FDN, FDA, hemicelulose, lignina e DIVMS. Foram determinados ainda os teores e extração dos nutrientes: N, P, Ca e S e os teores de PB foram obtidos a partir do teor do $\mathrm{N}$ multiplicado pelo fator 6,25 . As relações N/S e $\mathrm{Ca} / \mathrm{P}$ também foram calculadas. Os resultados obtidos permitem afirmar que para ambos os capins, as produções de matéria seca, variaram em função das épocas de vedação e de uso, aumentando com o tempo. A digestibilidade, foi afetada principalmente pelos teores de lignina. A extração de nutrientes da matéria seca, coincidiu com as máximas produções, sendo verificadas deficiências de $N$ e $P$ e inadequada relação N/S. Visando-se conciliar produção de matéria seca e valor nutritivo para Brachiaria brizantha cv. Marandu e para o Panicum maximum cv. Mombaça, recomenda-se para aquela a vedação da pastagem no início de março e para esta no final de março, por se apresentarem mais adequadas para uso durante o periodo seco, preferencialmente em julho e agosto, respectivamente. 
PASTURE STOCKPILING PERIOD OF BRACHIARIA GRASS (Brachiaria brizantha cv. Marandu) AND PANICUM GRASS (Panicum maximum cv. Mombaça)

\author{
Author: MOEMA FERREIRA BUENO \\ Adviser: Prof. Dr. HERBERT BARBOSA DE MATTOS
}

\title{
SUMMARY
}

The present experiment was carried out in Brotas, SP with the objetive of determining the most suitable time for shutting up paddocks of Brachiaria grass and Panicum grass for accumulating herbage to be used for supplementation purposes during the dry season of the year. Treatments comprised a combination of three closure dates (March 10, March 24 and April 07) and four utilization dates (June 27, July 25, August 25 and September 22). The experiment was laid out on the field according to a complete randomised blocks desing, replicated four times, with treatements assigned to experimental units according to a split-splot arrangement. Closure dates corresponded to the main plots and utilization dates to the subplots. Herbage digestibility was strongly influenced by the lignin content The dry matter yields were different among the periods of stockpiling and increased with time but was lack of nutrients as $N$ and $P$ and inadequate relation between N/S. In order to obtain greater forage yields with better quality, it is suggested that stockpiling begin in March for Brachiaria to be used in July and for Panicum in last days of March to be used in August. 


\section{INTRODUÇÃO}

A pecuária é uma das principais atividades econômicas do Brasil e baseia-se quase somente no uso de pastagens para o suprimento de nutrientes para os animais, principalmente por se constituir a fonte mais econômica para a alimentação animal.

Um dos maiores problemas das pastagens do Brasil central e sudeste, é a estacionalidade de produção apresentada pelas forrageiras, bastante acentuada com cerca de 80 a $85 \%$ dessa produção concentrada no periodo chuvoso (outubro a março), com bom valor nutritivo, proporcionando desempenho satisfatório dos animais. $\mathrm{Na}$ época de estiagem (abril a setembro) entretanto, quando essa produção está em torno de 15 a $20 \%$, observa-se uma acentuada diminuição na capacidade de suporte das pastagens, provocando na maioria das vezes perda de peso pelo animal ou redução na produção leiteira (Costa et al.,1993). Conservar excesso de forragem produzida na época chuvosa, através da fenação ou ensilagem, são altemativas viáveis, porém onerosas. Uma prática alternativa viável e mais econômica para amenizar o desequilibrio entre o suprimento e a demanda, ao longo do ano, seria reservar os pastos durante parte do periodo vegetativo da planta, propiciando acúmulo de forragem para uso durante a época seca, caracterizando o pastejo diferido. Diversas pesquisas com forrageiras tropicais, ressaltaram a viabilidade da vedação de pastagens, quando as espécies selecionadas forem adequadas. (Quesemberry e Ocumpaugh, 1982; Costa et. al., 1981; Omaliko, 1983; Costa et. al., 1988 e Costa et. al., 1993).

Nesse contexto, o presente trabalho teve por finalidade verificar quais as épocas mais adequadas para a vedação de pastagens e seu uso durante o período das secas, em duas áreas experimentais com forrageiras distintas como plantas-teste: Brachiaria brizantha cv. Marandu e Panicum maximum cv. Mombaça. 


\section{REVISÃO DE LITERATURA}

\subsection{Espécies forrageiras utilizadas: Brachiaria brizantha cv. Marandu e Panicum maximum cv. Mombaça}

O capim Marandu, como é conhecido ou a Brachiaria brizantha cv. Marandu, é originária da África (Zimbabwe), sendo avaliada e lançada pela EMBRAPA - Centro Nacional de Pesquisa de Gado de Corte - CNPGC (1984). Trata-se de uma planta de crescimento ereto, porte médio, apresentando intenso perfilhamento na base e folhas largas, com bainhas pilosas. Exige solos de boa fertilidade, sendo entretanto, persistente, tolerante à presença de alumínio, seca e frio, podendo inclusive ser recomendada para cerrados de média a boa fertilidade (Nunes et. al., 1985). Apresenta bom desempenho produtivo, com boa capacidade de rebrota e com taxa de crescimento diário da forragem de $6,4 \mathrm{~m}^{2}$ e $4,1 \mathrm{~m}^{2}$ nos períodos das águas e secas, respectivamente e percentagem de folhas de $30,8 \%$ e $23 \%$, respectivamente (Rodrigues et al., 1995). De acordo com Paulino et al. (1995), no Brasil, as áreas cultivadas com pastagens do gênero Brachiaria são expressivas, constituindo-se a base da alimentação do rebanho, ocupando milhões de hectares do território nacional .

Originário da África tropical, o Panicum maximum, caracteriza-se por ser capim pioneiro, com diversidade morfológica entre cultivares, ocupando solos recém desmatados e áreas de pastagens, com habitat abrangente (até $1800 \mathrm{~m}$ do nível do mar), sendo distribuídos numa amplitude de $40^{\circ} \mathrm{S}$ até $50^{\circ} \mathrm{N}$ de latitude, com predominância na zona equatorial úmida; em áreas com índices pluviométricos anuais iguais ou superiores a $760 \mathrm{~mm}$. Entretanto, por apresentarem fisiologia $\mathrm{C}_{4}$, reduzem suas taxas fotossintéticas a temperaturas inferiores a $15^{\circ} \mathrm{C}$, caracterizando um dos 
principais fatores causadores de sua estacionalidade de produção (Silva, 1995). Lançado e avaliado pela EMBRAPA - Centro Nacional de Pesquisa de Gado de Corte CNPGC (1993), o Panicum maximum cv. Mombaça, apresentou características agronômicas, segundo Jank (1995), superiores ao cV. Colonião, sendo $136 \%$ mais produtivo, com rebrota e produção de folhas $70 \%$ e $32 \%$ superior, respectivamente, e atingindo taxas de crescimento diário de $7,3 \mathrm{~m}^{2}$ e de $43 \%$ para percentagem de folhas durante o período das águas e de $4,1 \mathrm{~m}^{2}$ e $35,1 \%$ para a estação seca (Rodrigues et al., 1995), revelando seu grande potencial produtivo.

\subsection{Vedação: aspectos de manejo}

Resultados obtidos pela EMBRAPA - CNPGC (1982), aos 90 dias após a semeadura da Brachiaria brizantha cv. Marandu, relataram produções de MS, onde esse cultivar apresentou $6250 \mathrm{~kg} / \mathrm{ha}$ de MS total, com $41 \%$ de folhas, $57 \%$ de talos e $2 \%$ de material morto. Posteriormente, os experimentos de pastejo, mostraram que as quantidades de forragem de capim Marandu disponíveis em MS, em diversas épocas do ano, oscilaram entre 8,0 e 4,0 t/ha, para os meses de novembro e junho, respectivamente, sob duas cargas - animal 1,4 e 1,8 UA/ha, em pastejo contínuo. Nesse mesmo experimento, no primeiro ano de uso, o capim Marandu apresentou bons teores médios de PB e FDA obtidos na MS da planta inteira e nos componentes folha, talo e material morto para as épocas de seca e chuvas, não apresentando diferença significativa em relação ao parâmetro PB entre as épocas estudadas. Quanto à digestibilidade , a análise de digestibilidade "in vitro", realizada no primeiro período de seca forneceu teores médios de $33,80 \%$ para 1,8 UA/ha e $35,74 \%$ para 1,4 UA/ha.

Costa (1989), avaliou a vedação de pastagens em abril, testando 20 gramíneas dos gêneros Andropogon, Brachiaria, Panicum, Setaria, Cynodon e Paspalum e quatro épocas de uso (junho, julho, agosto e setembro) em Rondônia e concluiu que as gramíneas mais promissoras em termos de produção de forragem foram Brachiaria humidicola e Andropogon gayanus cv. Planaltina e que os rendimentos de matéria seca (MS) com razoável valor nutritivo foram obtidos com a uso do pasto em julho, agosto e setembro, sendo a uso das pastagens em junho desaconselhável devido aos baixos rendimentos de MS apresentados, apesar dos maiores teores de proteína bruta 
(PB) fomecidos. Ainda segundo Costa et al. (1993), trabalhando com Brachiaria brizantha em Porto Velho, RO, utilizando três épocas de vedação (fevereiro, março e abril) obtiveram resultados que definem a viabilidade da vedação de pastagens de Brachiaria brizantha cv. Marandu ao final do periodo chuvoso, de modo a se obter forragem para a suplementação do rebanho durante o período seco; sendo que a vedação em abril com utilizações em junho e julho proporcionou forragem com maiores teores de PB. Entretanto, os maiores rendimentos de MS foram obtidos com a vedação em fevereiro e uso em agosto e setembro; sendo os maiores coeficientes de digestibilidade "in vitro" da matéria seca (DIVMS) obtidos com a vedação em março ou abril e uso em junho e, finalmente, objetivando conciliar os rendimentos de matéria seca (MS) com a obtenção de forragem de boa qualidade, os autores recomendaram a vedação em fevereiro para uso em junho e julho e, vedação em março para uso em agosto e setembro, para as pastagens nas condições de Porto Velho.

Euclides et al. (1990), avaliaram forrageiras para produção de "feno em pé", utilizando Brachiaria decumbens, B. humidicola e Cynodon plectostachyus (Capim Estrela), relatando que independentemente da época de vedação ser em janeiro, fevereiro ou março, as forrageiras apresentaram decréscimos em MS, conteúdos de PB e DIVMS, durante o período de uso, ressaltando produções de MS no período em torno de 2 t/ha, níveis superiores a $6 \%$ de PB e digestibilidade variando de 62 a $58 \%$ para as braquiárias e de 55 a $50 \%$ para o capim estrela durante o período seco, possibilitando apenas a mantença dos animais no periodo crítico de invemo.

Pizarro et al. (1997), avaliaram na EMBRAPA - Região dos Cerrados, uma coleção multiespecífica do gênero $B$. decumbens, em relação à produção e estacionalidade da forragem, capacidade de rebrota e valor nutritivo, destacando o genótipo CIAT (BRA), comportando-se de maneira semelhante quando vedou-se a $B$. brizantha CV. Marandu. Os resultados apresentados demonstraram que a forragem disponivel ao longo do periodo crítico para a pastagem diferida entre dezembro e fevereiro permitiram o uso desse genótipo visando a produção de feno em pé.

Jank e Costa (1990), avaliaram num ensaio 156 acessos de Panicum maximum introduzidos pela EMBRAPA-Centro Nacional de Pesquisa de Gado de Corte (CNPGC) e constataram que $40 \%$ desses acessos apresentaram melhor distribuição estacional na produção de forragem e foram mais produtivos que o cultivar colonião. A variedade Mombaça foi classificada como a $6^{a}$ melhor entre os 156 acessos quanto à produção 
de matéria seca foliar (t/ha) enquanto Tanzânia foi classificada em 15ำ lugar. Quanto à estacionalidade de produção, tanto Tanzânia como Mombaça são comparáveis $\left(54^{\circ} \mathrm{e}\right.$ $\left.52^{\circ}\right)$, na classificação entre os 156 acessos. Destes acessos, os 25 melhores foram submetidos a nova avaliação em ensaios regionais, selecionando-se os sete melhores (Jank et al., 1993). Prosseguindo, com o processo de avaliação, Euclides et al. (1995) compararam os sete melhores ecotipos com os capins Tobiatã (Panicum maximum cv. Tobiatã) e Marandu (Brachiaria brizantha cv. Marandu), sendo que um dos ecotipos selecionados foi o cv. Mombaça. Dentre as sete variedades de Panicum maximum testadas, os resultados demonstraram que todos os ecotipos apresentaram maiores percentagens de folhas do que o cv. Marandu nos periodos das águas e secas, sendo que o cv. Mombaça apresentou maiores percentagens de folhas (43\%) em relação ao cv. Tobiatã $(38,1 \%)$, para o periodo das águas e, quando outras características usadas para estimar a qualidade e quantidade de forragem foram consideradas, como percentagem de matéria seca, foi possivel identificar o cv. Mombaça como superior às testemunhas quanto à capacidade de suporte e à produção por animal (Rodrigues e Reis, 1995).

Valle et al. (1988), testando cinco espécies de Brachiaria (oriundos de diferentes localidades), sendo a $B$. brizantha uma das espécies testadas em relação à composição de parede celular e digestibilidade, relatando que os caules apresentaram maiores concentrações de celulose e lignina e igual ou maiores concentrações de hemicelulose em relação às folhas para todas as espécies estudadas; e que a digestibilidade da parede celular das folhas foi 150 a $200 \mathrm{~g} . \mathrm{kg}^{-1}$ maior do que a encontrada nos caules para as mesmas espécies. B. brizantha apresentou menor digestibilidade da matéria seca (DMS), valores intermediários para fibra em detergente neutro (FDN), fibra em detergente ácido (FDA), celulose e lignina e maiores concentrações de hemicelulose medidos nas folhas. Para os caules apresentou concentraçōes maiores em FDA, celulose e lignina, intermediárias em FDN e menores em hemicelulose e DMS em relação às demais espécies testadas.

Pizarro et al. (1993), na estação experimental da EPAMIG, utilizaram pastagem formada há dez anos, de Panicum maximum para vedação de janeiro a março e cortes a cada 21 dias por dois anos consecutivos, relatando resultados positivos em relação a proteina bruta, com vedações no final das águas, apresentando menores teores de proteina bruta para as vedações de janeiro, variando também a proporção entre os 
componentes da planta (caule e folhas) com a data de corte. Obtiveram correlação negativa entre matéria seca e proteina bruta em relação às épocas de vedação e uso, demonstrando que Panicum maximum quando vedado apresentou o mesmo comportamento que as outras forrageiras normalmente utilizadas; concluindo a importância dessa prática como econômica e responsável pela uso da forrageira em questão nos períodos de seca, mantendo a persistência da pastagem.

De maneira similar, Molina et al. (1996), na Venezuela, utilizando vedação em pastagens consorciadas de Panicum maximum - Leucaena leucocephala, inferiram que quando o pasto é vedado mais no final do periodo das águas (fev.-mar.), permite maiores valores de proteina bruta e matéria orgânica digestivel na uso, constituindo-se alternativa para fornecimento de forragem de boa qualidade na seca. Por outro lado, a produção da leguminosa foi maior tanto em matéria seca quanto em nutrientes, para todos os tratamentos.

Guzmán et al. (1994), no noroeste da Argentina, em clima semi-árido e déficit hidrico permanente, vedou as diferentes forrageiras: Panicum maximum cv. Gatton e cv. Green, Cenchrus ciliaris cv. Biloela e cv. Texas e Chloris gayana cv. Tuc. Oriental em dois anos consecutivos, as avaliações foram feitas no intervalo de junho a setembro, demonstrando que Cenchrus ciliaris cv. Biloela apresentou maiores produções de matéria seca no inverno em relação às outras forrageiras; Chloris gayana cv. Tuc Oriental e Panicum maximum cv. Green, apresentaram máxima produção de matéria seca no início do inverno, recomendando-se o uso antes das geadas e Panicum maximum cv. Gatton mesmo sendo afetado por geadas, mantém a produção de matéria seca por periodo de tempo maior que a cv. Green, podendo ser aproveitado por tempo maior.

Pedreira (1973), testando o capim colonião, obteve para a média de 5 anos, a taxa de crescimento de $48 \mathrm{~kg} \mathrm{MS} / \mathrm{ha} /$ dia entre os meses de outubro e março e de aproximadamente $7 \mathrm{~kg} \mathrm{MS} / \mathrm{ha} / \mathrm{dia}$ para o periodo de abril até setembro.

Em relação à estacionalidade de produção, Jank et al. (1994), apontaram que devem ser mensurados os resultados da produção de matéria seca para os cultivares de Panicum maximum no inverno, e não o percentual de produção no inverno em relação à produção anual, a fim de melhor refletir o potencial da planta forrageira que atenda às necessidades de alimentos durante o periodo; uma vez que, analisando-se simplesmente a quantidade de forragem produzida no inverno, variedades como 
Tanzânia I e Mombaça produziram 2,55 vezes mais do que variedades que destacaram-se pela melhor distribuição (uniformidade) de produção de forragem no inverno em relação à produção anual.

Andrade et al. (1990), em localidades distintas, no estado de Minas Gerais, utilizaram quatro épocas de vedação (janeiro, fevereiro, março e abril) e seis épocas de uso (maio, junho, julho, agosto, setembro e outubro) sobre a produção e valor nutritivo do capim elefante cv. Cameroon, blocos ao acaso, três repetições, sendo realizadas adubações de plantio com $300 \mathrm{~kg} / \mathrm{ha}$ da fórmula 4-14-8, cobertura com $350 \mathrm{~kg} / \mathrm{ha}$ da mesma fórmula antes das vedações e $200 \mathrm{~kg} / \mathrm{ha}$ de uréia após as brotações dos cortes de vedação. Pelo teste de comparação de médias, os autores inferiram que para a capineira ser utilizada no início do período seco deve ser vedada em janeiro, vedações em fevereiro resultam em períodos de uso no meio do período seco; enquanto que para a uso no final da seca, a vedação deverá ser feita em março, sendo a vedação de abril desaconselhável por apresentar pequena quantidade de forragem. Quanto aos teores de PB na MS, as melhores épocas de vedação foram março e abril com amostragens em maio e junho e, em relação aos outros parâmetros avaliados, FDN, FDA, lignina, teores de $\mathrm{P}, \mathrm{Ca}$, e DIVMS, os autores concluíram que o capim amostrado mais novo é sempre melhor, priorizando contudo, qualidade e quantidade na uso de capineiras.

Andrade (1993), testou em Três Pontas, MG, durante três anos consecutivos diferentes épocas de vedação (janeiro, fevereiro e março) e períodos de uso (maio, junho, julho, agosto ou setembro) na produção e valor nutritivo do capim elefante cv. Mineiro, relatando que nos três anos de condução do experimento, foi verificado efeito significativo devido à época de vedação e uso em relação aos teores de MS e PB, sendo que em relação ao valor nutritivo, forrageiras mais novas são sempre melhores, por apresentarem maiores quantidades de PB, cálcio e fósforo na MS. Já em relação à produção o autor recomenda que se a capineira for utilizada no início da seca ela deve ser vedada em janeiro; se o seu uso se der mais ao final da seca, esta deve ser vedada em fevereiro; enquanto que vedações ao final de março e em abril rendem geralmente pequenas quantidades de forragem.

Fontaneli et al. (1994), estudaram os efeitos de diferentes tratamentos: ceifa, queima, vedação e adubação sobre uma pastagem nativa nas condições de Passo Fundo, RS; sendo que os tratamentos vedação feito com $200 \mathrm{~kg} / \mathrm{ha}$ da fórmula $5-20-20$ 
e também sem adubação, roçados a $4 \mathrm{~cm}$ do nível do solo no final de fevereiro e início de março, apresentaram maior disponibilidade de MS da forragem em relação à queima, na média durante o ano; entretanto o tratamento queima foi superior aos tratamentos vedação no outono e inverno. Em relação aos teores de $\mathrm{PB}$, os autores mostraram que os tratamentos vedação não variaram estatisticamente dos demais.

Barbosa et al. (1995), em condições de campo no município de Capão do Leão, RS, avaliaram o efeito de três épocas de vedação (22/01, 25/02 e 25/03/86) e quatro épocas de corte (abril, maio, junho e julho) sobre produção e qualidade da forragem de capim elefante (Pennisetum purpureum) cv. Vruckwona, obtendo diminuição das produções de MS e PB da primeira para a terceira época de vedação e aumento crescente nas produções de MS e PB da primeira à última época de corte, sendo a época da realização da vedação do capim elefante mais determinante na produção e qualidade da forragem do que a época de corte. Os autores relataram também que o vedação no terço final do verão (março) originou baixa produção de forragem, mas com melhor qualidade e, quando o objetivo for uma forragem de melhor qualidade no outono, a vedação deve ser realizado em fevereiro ou março.

\subsection{Aspectos nutricionais}

De acordo com Underwood (1971) ocorrem variações nos niveis dos minerais encontrados em forrageiras devido a espécie vegetal, características edafoclimáticas na estação de crescimento, estádio de maturidade da planta e nível de produção. Fleming (1973), complementou com fatores relacionados à velocidade de crescimento, produção de MS, relação folha:haste, tratos culturais no solo e relações entre nutrientes, entre outras, relatando a dificuldade do isolamento a campo de efeitos somente do estádio de maturidade da planta ou das variações no clima em relação à períodos de estiagem ou de águas.

Ainda de acordo com Fleming (1973), em relação ao estádio de maturidade da planta para sua composição mineral, o autor infere que ocorrem absorções relativamente rápidas de minerais nos estádios iniciais de crescimento, devido à produção de MS ser lenta. Com o aumento da área fotossintética a produção de MS ultrapassa a absorção de mineral, conferindo um processo natural de diluição, 
declinando o conteúdo dos minerais na planta, existindo exceções principalmente com alguns micronutrientes, com grande variação no conteúdo para as diferentes espécies; ocorrendo devido à variação nos órgãos da planta em relação a composição mineral, que com a maturidade, podem variar as proporções, como as que ocorrem na relação folha:haste resultando em várias mudanças encontradas. $E$, dependendo do nutriente, seu teor pode aumentar, diminuir ou se manter constante com a maturidade da planta. De maneira concordante, Little (1982), relatou que as mudanças no conteúdo mineral que ocorrem com o avanço da maturidade estão associadas às variações na relação folha:haste, no florescimento e na produção de sementes. Para Malavolta et al. (1986) a variação na composição mineral das forrageiras ao longo da maturidade foi atribuída à redistribuição dos nutrientes na planta; perdas de nutrientes solúveis por lixiviação; excreção pelas raizes e diferenças no padrão de absorção ao longo do ciclo.

Segundo Fick et al. (1978), os registros encontrados no Brasil, demonstram deficiências de $\mathrm{Ca}, \mathrm{P}$ e $\mathrm{S}$, entre outros nutrientes, sendo a concentração de $\mathrm{Ca}$ na forragem influenciada pela quantidade de $\mathrm{Ca}$ trocável no solo, pelo nivel de outros nutrientes, como $\mathrm{N}$ e $\mathrm{K}$ e pelo ritmo de crescimento, sendo normalmente baixa durante períodos de crescimento ativo da planta e alta em baixas temperaturas ou umidade, retardando o crescimento da planta.

Para Underwood (1981), a nutrição adequada de Ca e $P$ é dependente do suprimento desses minerais e da relação $\mathrm{Ca} / \mathrm{P}$ na dieta, assumindo que uma relação entre $1 / 1$ a $2 / 1$, seja ideal para o crescimento e formação dos ossos para os animais, por ser similar à relação observada nos mesmos. Minson (1990), analisando vários trabalhos, observou teores de $3,8 \mathrm{~g} \mathrm{~kg}^{-1}$ de $\mathrm{Ca}$ em gramineas tropicais e, em gramíneas tropicais e temperadas, os teores de $\mathrm{P}$ apresentaram-se em torno de $3,6 \mathrm{~g}$ $\mathrm{kg}^{-1}$, sendo acima de $2,4 \mathrm{~g} \mathrm{~kg}^{-1}$ em $35 \%$ das amostras de gramíneas tropicais, preconizando que as exigências suficientes de $\mathrm{Ca}$ para ruminantes, provavelmente estão em torno de $4 \mathrm{~g} \cdot \mathrm{kg}^{-1}$. Norton (1992), em revisão na literatura, observou que $63 \%$ das amostras de capins tropicais continham baixas concentrações de $P$ em estádios de maturação avançados, independentemente da aplicação de fertilizante fosfatado e que a concentração de $P$ foi deficiente em relação às exigências animais, observando também deficiências de $\mathrm{Ca}$ (teores inferiores a $4,3 \mathrm{~g} \mathrm{~kg}^{-1}$ ) para animais em crescimento. 
De acordo com Church (1993), a necessidade de $S$ para ruminantes é expressa na forma de relação N/S, sendo também um dos parâmetros mais indicados para avaliar o estado nutricional da planta quanto ao enxofre, por manter-se relativamente constante nos estádios de desenvolvimento da planta, estabilizando em 14/1 com a maturidade, relatando também ocorrência de deficiências de $S$ para ruminantes, caso a dieta seja baseada somente no consumo de forragem (Vitti e Novaes, 1986). Para a produção vegetal máxima, a relação N/S de 12/1 a 15/1 é satisfatória (Follett e Wilkinson, 1995) e, segundo Reid e Jung (1974), o valor atingido para o desenvolvimento da planta é, geralmente, um pouco mais elevado que o ideal para a nutrição de ruminantes. 


\section{MATERIAL E MÉTODOS}

\subsection{Localização do experimento}

O experimento foi conduzido na Fazenda Mundo Novo, no município de BrotasSP. A propriedade apresentava-se subdividida em pastos radiais, onde utilizou-se duas áreas experimentais distintas, cada uma delas de $1800 \mathrm{~m}^{2}$. As áreas encontravam-se cultivadas com: Brachiaria brizantha cv. Marandu, cujo pasto apresentava sete anos de formação e Panicum maximum cv. Mombaça, cujo pasto apresentava em torno de um ano e meio de formação.

$A$ área experimental encontra-se a $22^{\circ} 10^{\prime} S$ de latitude e $48^{\circ} 02^{\prime} W$ de longitude. A topografia do local é levemente ondulada e a altitude $700 \mathrm{~m}$ acima do nivel do mar.

\subsection{Clima}

O clima da região, de acordo com a classificação de Köppen, corresponde ao tipo Cwa, com inverno seco e verão chuvoso. As temperaturas médias máximas e mínimas registradas no ano são de $22^{\circ} \mathrm{C}$ e $18^{\circ} \mathrm{C}$, no mês mais quente e mais frio, respectivamente. $O$ indice pluviométrico varia entre 1.100 e $1.700 \mathrm{~mm}$ anuais, com estação seca entre os meses abril a setembro (Ministério da Agricultura, 1979). Na área experimental, foram registradas temperaturas máximas e mínimas para 0 ano de 1997 de $36,7^{\circ} \mathrm{C}$ e $10,9^{\circ} \mathrm{C}$ em dezembro e julho, respectivamente. A precipitação total anual foi de $1326 \mathrm{~mm}$, sendo que os meses de janeiro e fevereiro apresentaram as maiores precipitações e agosto foi o mês mais seco, apresentando $0 \mathrm{~mm}$ de precipitação (Figura 1). 


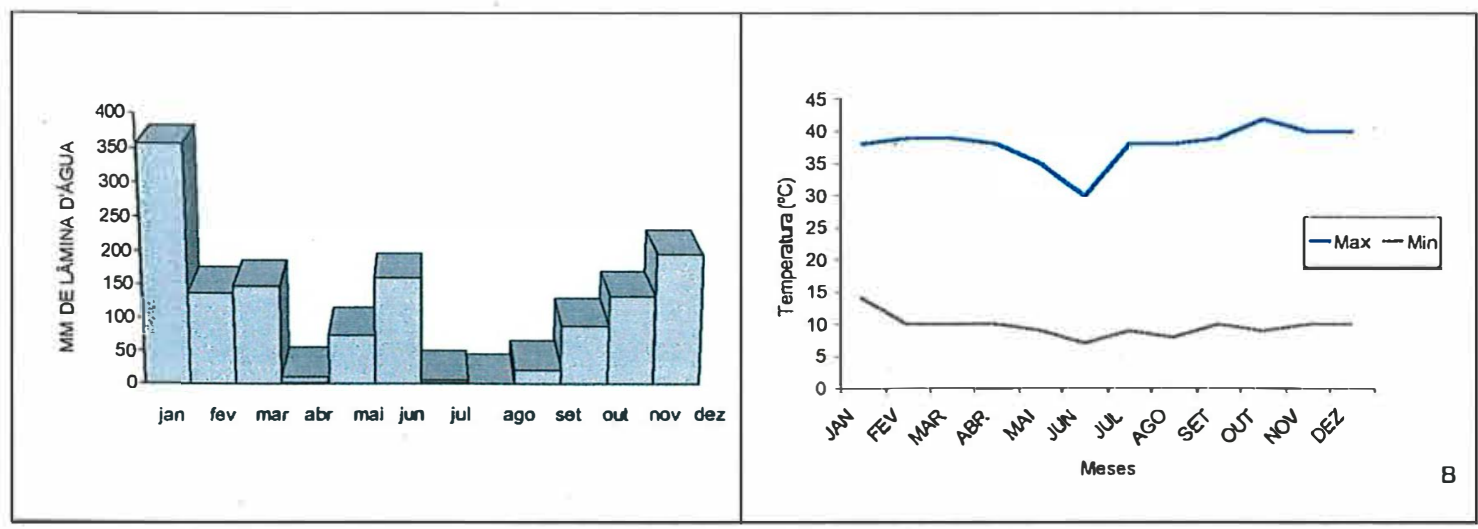

Figura 1. A- Precipitação pluvial (mm de lâmina d'água acumulada);

B-Temperatura máxima e mínima $\left({ }^{\circ} \mathrm{C}\right)$ para os meses de janeiro a dezembro de 1997.

\subsection{Solo e tratos culturais}

O solo é classificado como latossolo vermelho amarelo-fase escura para ambas as áreas, apresentando para as áreas cultivadas com Brachiaria brizantha cv. Marandu e Panicum maximum cv. Mombaça, as características químicas de acordo com a análise de solo da Tabela 1.

Tabela 1. Resultados da análise química de terra da área experimental (profundidade: 0 a $20 \mathrm{~cm}$; uso: fevereiro de 1997) $)^{(1)}$.

\begin{tabular}{|c|c|c|c|c|c|c|c|c|c|c|}
\hline & $P$ & M.O & $\mathrm{pH}$ & $\mathrm{K}$ & $\mathrm{Ca}$ & $\mathrm{Mg}$ & $\mathrm{H}+\mathrm{Al}$ & \multirow[t]{2}{*}{ S } & \multirow[t]{2}{*}{$\mathrm{T}$} & \multirow[t]{2}{*}{ V\% } \\
\hline & res & (\%) & $\mathrm{CaCl}_{2}$ & \multicolumn{4}{|c|}{$\mathrm{meq} / \mathrm{cm}_{3}$} & & & \\
\hline Brachiaria & 5,9 & 2,7 & 3,95 & 0,08 & 0,39 & 0,13 & 4,35 & 0,60 & 4,95 & 11,65 \\
\hline Panicum & 6,2 & 2,1 & 5,18 & 0,10 & 1,09 & 0,68 & 2,25 & 1,90 & 4,10 & 45,10 \\
\hline
\end{tabular}

"TI Análise realizada no Laboratório de Nutrição Mineral de Plantas do Depto. de Química da ESALQ/USP.

Para a Brachiaria brizantha cv. Marandu foram realizadas adubações em novembro de 1994, na qual utilizou-se aproximadamente $288 \mathrm{~kg} / \mathrm{ha}$ do fertilizante FOSMAG 511 M6 o qual apresenta os seguintes nutrientes em $\mathrm{kg} / \mathrm{t}: \mathrm{N}=0, P=180$, $K=100, C a=130, M g=20, S=70, Z n=6, B=2, C u=2, M n=1, M o=0,1$ e $C o=0,02$ e em março de 1997, $160 \mathrm{~kg} / \mathrm{ha}$ de nitrato de amônio. Para o Panicum maximum cv. 
Mombaça, foi realizada calagem em agosto de 1995, com $2000 \mathrm{~kg} / \mathrm{ha}$ de calcário dolomítico e, posteriormente em outubro de 1995, por ocasião do plantio, fez-se novamente a calagem com o emprego de $1300 \mathrm{~kg} / \mathrm{ha}$ de calcário dolomítico, bem como a adubação utilizando-se $300 \mathrm{~kg} / \mathrm{ha}$ do mesmo fertilizante citado anteriormente.

\subsection{Delineamento experimental e análises laboratoriais}

O periodo do experimento estendeu-se de fevereiro até setembro de 1997. O delineamento experimental utilizado foi o de blocos completos ao acaso, com parcelas subdivididas e quatro repetições, num total de 12 parcelas e 48 subparcelas, para cada forrageira. Cada parcela experimental com $72 \mathrm{~m}^{2}$ (época de vedação) foi dividida em 4 subparcelas (períodos de uso) de $6 \times 3 \mathrm{~m}$ com área útil $4 \times 1 \mathrm{~m}$, após a eliminação de $1 \mathrm{~m}$ de cada lado para bordadura. Os tratamentos utilizados constituiram-se de: três épocas de vedação (10 de março, 24 de março e 07 de abril) com intervalos de 14 dias entre cada uma, e quatro períodos de uso ( 27 de junho, 25 de julho, 25 de agosto e 22 de setembro). O início do experimento ocorreu em 25 de fevereiro de 1997 com o isolamento da área da forrageira em questão escolhida dentro do seu respectivo pasto, com uniformização à $20 \mathrm{~cm}$ de altura, através do rebaixamento realizado por carga animal.

O corte da área útil das parcelas nas duas áreas experimentais foi realizado com uso de motosegadeira Lusbra, modelo Nova Odessa a $10 \mathrm{~cm}$ acima do nivel do solo e a forragem obtida das parcelas foi pesada e retiradas amostras em tomo de $300 \mathrm{~g}$, as quais foram secas em estufa de circulação e renovação forçada de ar à 65$70^{\circ} \mathrm{C}$ por 72 horas para determinação do teor de matéria seca pelo método da AOAC (1995). Quanto às épocas de uso, para as duas forrageiras foi feito o corte da área útil das subparcelas, utilizando-se a mesma máquina e mesma altura de corte. $A$ forragem colhida recebeu a mesma metodologia já descrita acima. As amostras foram então moídas em moinho tipo Willey, com peneira de $1 \mathrm{~mm}$. Posteriormente o material foi homogeneizado e armazenado em sacos plásticos para ser encaminhado ao laboratório para a determinação das análises bromatológica e mineral, sendo determinada a matéria seca a $105^{\circ} \mathrm{C}$ pelo método da AOAC (1995) e, a partir daí, quantificadas as variáveis estudadas: teores de FDN, FDA, hemicelulose e lignina pelo 
método de Goering e Van Soest (1975), usando-se para essa finalidade o Fiber Analyser, modelo ANKOM 200, juntamente com sacos de papel de filtro (fiber bags). Os coeficientes de digestibilidade "in vitro" da MS (DIVMS), foram quantificados, segundo a técnica descrita por Tilley e Terry (1963) modificada por Tinnimit (1974).

A análise mineral foi realizada de acordo com as metodologias para análises químicas (Malavolta et al., 1989): $\mathrm{N}$ pelo método semimicro Kjeldhal, cujo teor de proteína bruta (PB), foi obtido pela multiplicação do teor de $\mathrm{N}$ total pelo fator 6,$25 ; \mathrm{P}$ por colorimetria do metavanadato (fósforo total); $\mathrm{Ca}$ por espectrofotometria de absorção atômica e o $\mathrm{S}$ foi determinado indiretamente em espectrofotometria de absorção atômica, com uso do sulfato de bário, segundo Bataglia (1976). As relações $\mathrm{N} / \mathrm{S}$ e Ca/P também foram calculadas, para fins de quantificação da inter-relação entre esses nutrientes na planta.

\subsection{Análises estatísticas}

As análises estatisticas (teste de Tukey, ao nivel de $5 \%$ de significância), foram realizadas com auxilio do programa Sistema de Análises Estatisticas SAS (SAS Institute, 1988) 


\section{RESULTADOS E DISCUSSÃO}

\subsection{Produção de forragem}

\section{1. 1 Brachiaria brizantha cv. Marandu}

O acúmulo de forragem de Brachiaria brizantha cv. Marandu obtida do início da reserva do pasto em fevereiro até as respectivas épocas de vedação foram quantificadas, e os acúmulos de matéria verde (MV) e matéria seca (MS) apresentaram respectivamente, na época de vedação em 10/03, valores de $468 \mathrm{~g} / 40 \mathrm{~m}^{2}$ e $200 \mathrm{~g} / 40 \mathrm{~m}^{2}$; para a vedação em 24/03, $1.900 \mathrm{~g} / 40 \mathrm{~m}^{2}$ e $759 \mathrm{~g} / 40 \mathrm{~m}^{2}$ e para a pastagem vedada em $07 / 04,2.600 \mathrm{~g} / 40 \mathrm{~m}^{2}$ e $1.032 \mathrm{~g} / 40 \mathrm{~m}^{2}$, (onde $40 \mathrm{~m}^{2}$ consistem o tamanho da parcela).

As produções em MS, variaram significativamente somente entre as épocas de vedação, conforme apresentado na Tabela 2 e Figura 2.

Tabela 2. Produção de matéria seca $\left(\mathrm{g} \cdot \mathrm{m}^{-2}\right)$ da parte aérea da Brachiaria brizantha cv. Marandu em relação às épocas de vedação e períodos de uso utilizados (média de quatro repetições).

\begin{tabular}{llllll}
\hline \multirow{2}{*}{$\begin{array}{l}\text { Épocas de } \\
\text { Vedação }\end{array}$} & \multicolumn{5}{c}{ Períodos de Uso } \\
\cline { 2 - 5 } & Junho & Julho & Agosto & Setembro & Média \\
\hline \multirow{2}{*}{$10 / 03 / 1997$} & 114,08 & 66,75 & 97,03 & 76,78 & $88,66 \mathrm{a}$ \\
$24 / 03 / 1997$ & 27,68 & 39,68 & 45,83 & 48,15 & $40,33 \mathrm{~b}$ \\
$07 / 04 / 1997$ & 31,35 & 48,03 & 33,38 & 39,95 & $38,18 \mathrm{~b}$ \\
& & & & & \\
\hline Média & $57,70 \mathrm{~ns}$ & $51,48 \mathrm{~ns}$ & $58,74 \mathrm{~ns}$ & $54.96 \mathrm{~ns}$ &
\end{tabular}




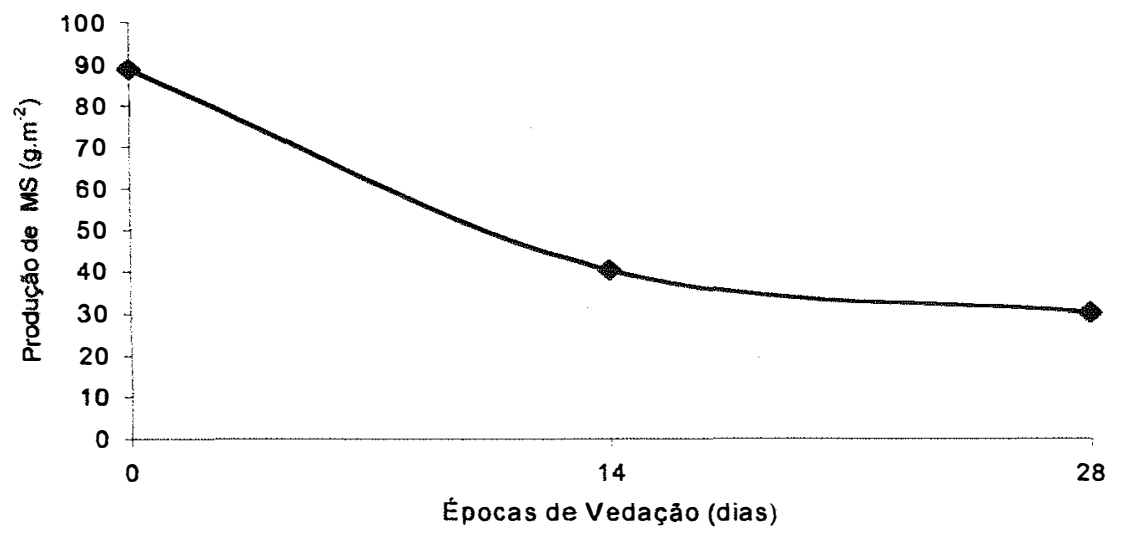

Figura 2. Produção de matéria seca $\left(\mathrm{g} \cdot \mathrm{m}^{-2}\right)$ obtida da parte aérea da Brachiaria brizantha cv. Marandu em função das épocas de vedação, onde 0 corresponde a vedação realizada em 10/03/97, 14 corresponde a vedação realizada em 24/03/97 e 28 corresponde a vedação realizada em 07/04/97.

As produções de matéria seca (MS) da Brachiaria brizantha cv. Marandu, variaram significativamente com as épocas de vedação, conforme apresentado na Figura 2, onde verificou-se distribuição decrescente em função da época de vedação, devido ao maior tempo à campo e condições climáticas favoráveis ao crescimento de gramíneas tropicais, comprovando dessa forma maior produção de MS com a maturidade da forragem. Para os períodos de uso, as variáveis não apresentaram diferenças significativas, a Figura 3 , apenas confirma a maior produção em MS, quando a pastagem foi vedada no início de março em relação às outras épocas de vedação utilizadas. 


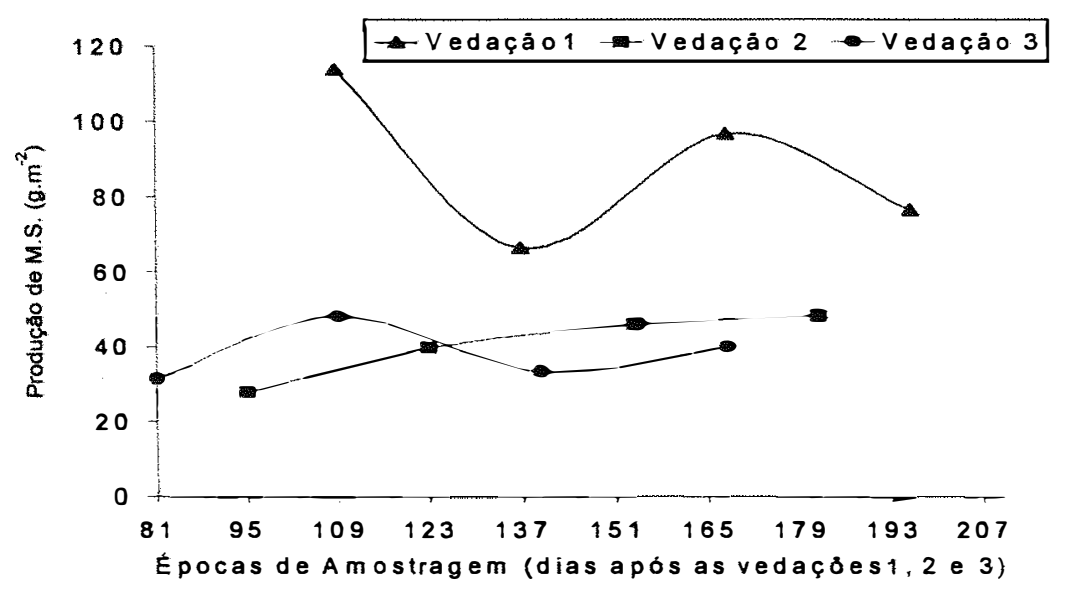

Figura 3. Produção de matéria seca $\left(\mathrm{g} \cdot \mathrm{kg}^{-1}\right)$, obtida da parte aérea da Brachiaria brizantha cv. Marandu em função dos períodos de uso avaliados - épocas de amostragem (junho, julho, agosto e setembro), em dias após as vedações 1 (10/03/97), 2 (24/03/97) e 3 (07/04/97).

Pela Tabela 3 e Figura 4, observou-se o padrão sigmóide para crescimento de gramíneas forrageiras tropicais, onde os maiores teores de MS, foram encontrados com o avanço da maturidade da mesma. Entretanto, as médias dos rendimentos de MS observadas em qualquer período de uso foram superiores aos valores observados por Costa (1984) em Porto Velho - RO, com uso de vedação de gramíneas forrageiras tropicais e Costa et al. (1988) em Ariquemes - RO, avaliando a produção de forragem de Brachiaria brizantha cv. Marandu, durante o periodo seco.

Tabela 3. Teores de matéria seca $\left(\mathrm{g} \cdot \mathrm{kg}^{-1}\right)$ da parte aérea da Brachiaria brizantha cv. Marandu em relação às épocas de vedação e períodos de uso utilizados (média de quatro repetições).

\begin{tabular}{llllll}
\hline Epocas de & \multicolumn{5}{c}{ Períodos de Uso } \\
\cline { 2 - 6 } Vedação & Junho & Julho & Agosto & Setembro & Média \\
\hline $10 / 03 / 1997$ & 568,05 & 458,30 & 597,08 & 609,85 & $558,32 \mathrm{~ns}$ \\
$24 / 03 / 1997$ & 525,23 & 463,75 & 602,40 & 579,05 & $542,61 \mathrm{~ns}$ \\
$07 / 04 / 1997$ & 525,68 & 534,85 & 651,78 & 624,18 & $584,12 \mathrm{~ns}$ \\
\hline Média & $539,65 \mathrm{ab}$ & $485,63 \mathrm{~b}$ & $617,08 \mathrm{a}$ & $604,36 \mathrm{a}$ & \\
\hline
\end{tabular}

Médias seguidas da mesma letra não diferem significativamente entre si $(P>0,05)$ pelo teste de Tukey. $n s=n a ̊ o ~ s i g n i f i c a t i v o ~(P>0,05)$ pelo teste de Tukey. C.V. $(\%)=18,31$ 


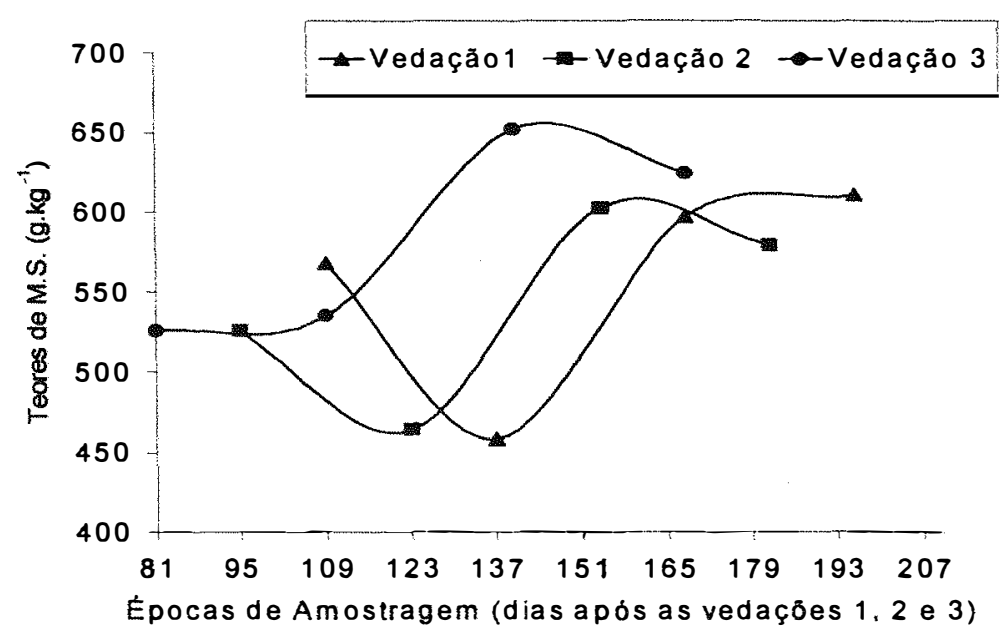

Figura 4. Teores de matéria seca $\left(\mathrm{g}^{\mathrm{kg}} \mathrm{kg}^{-1}\right)$ obtidos da parte aérea da Brachiaria brizantha $\mathrm{cv}$. Marandu em função dos períodos de uso avaliados - épocas de amostragem (junho, julho, agosto e setembro), em dias após as vedações 1 (10/03/97), 2 (24/03/97) e 3 (07/04/97).

Os teores de MS, para a Brachiaria brizantha cv. Marandu encontrados na Tabela 3 e Figura 4, apesar de não variarem significativamente com as épocas de vedação, apresentaram diferenças significativas, com maiores valores obtidos nos períodos de uso em agosto $\left(617,08 \mathrm{~g} \cdot \mathrm{kg}^{-1}\right)$ e setembro $\left(604,36 \mathrm{~g} \cdot \mathrm{kg}^{-1}\right)$, não diferindo significativamente de junho $\left(539,65 \mathrm{~g} \cdot \mathrm{kg}^{-1}\right)$, entretanto, esses teores apresentados foram mais elevados, do que os relatados por Sotomayor-Rios et al. (1974), trabalhando com Brachiaria, Digitaria e Cynodon, conferindo oscilações de 220,7 g para 272,3 g. $\mathrm{kg}^{-1}$ de MS com o aumento da idade de corte de 30 para 60 dias; uma vez que na avaliação da Brachiaria brizantha cv. Marandu, os períodos estudados foram mais longos

Costa et al. (1993), encontraram efeito da relação entre as épocas de vedação e os períodos de uso para MS, relatando rendimentos superiores quando utilizadas em junho, julho e agosto e vedação em fevereiro, sem variar da vedação em março com uso em junho, enquanto que para o uso em setembro, vedar em março ou fevereiro foi mais produtivo e independente das épocas de vedação avaliadas, as utilizações em agosto e setembro apresentaram maiores produções de MS. 


\section{1. 2 Panicum maximum cv. Mombaça}

A forragem acumulada de Panicum maximum cv. Mombaça do início da reserva do pasto em fevereiro até as respectivas épocas de vedação foram quantificadas, e os acúmulos de matéria verde (MV) e matéria seca (MS) apresentaram respectivamente, na época de vedação em 10/03, valores de $7.100 \mathrm{~g} / 40 \mathrm{~m}^{2}$ e $1853 \mathrm{~g} / 40 \mathrm{~m}^{2}$; para a vedação em 24/03, $5.125 \mathrm{~g} / 40 \mathrm{~m}^{2}$ e $1.817 \mathrm{~g} / 40 \mathrm{~m}^{2}$ e para a pastagem vedada em 07/04, $7.975 \mathrm{~g} / 40 \mathrm{~m}^{2}$ e $2.512 \mathrm{~g} / 40 \mathrm{~m}^{2}$ (onde $40 \mathrm{~m}^{2}$ consistem o tamanho da parcela).

Pela Tabela 4 e Figuras 5 e 6, observou-se maiores produções em MS para a vedação em 10/03 e períodos de uso em agosto e setembro, devido provavelmente ao maior tempo a campo e condições climáticas favorecendo o crescimento e consequentemente a maturidade das gramíneas forrageiras tropicais (Figura 1). As outras épocas de vedação 24/03 e 07/04 do Panicum, apresentaram menores produções em MS, comprovando que a medida em que a planta senesce, perde água e acumula MS. Valores similares de MS foram encontrados em Costa (1984), trabalhando com vedação de Panicum maximum, observaram rendimentos de MS de $138,00 \mathrm{~g} \cdot \mathrm{m}^{-2}$ para o cv. Comum a $246,00 \mathrm{~g} \cdot \mathrm{m}^{-2}$ para o cv. Tobiatã.

Costa et al. (1988), registraram produções de MS para vários cv. de Panicum maximum variando de $266,00 \mathrm{~g} \cdot \mathrm{m}^{-2}$ a $317,00 \mathrm{~g} \cdot \mathrm{m}^{-2}$, durante o período de junho a setembro, através de cortes a $25 \mathrm{~cm}$ acima do solo, sem utilizar vedação de forrageiras. Alcântara et al. (1981), relataram produções de MS para Panicum maximum cv. Colonião de $118,7 \mathrm{~g} \cdot \mathrm{m}^{-2}$ (média dos cortes no outono e inverno). 
Tabela 4. Produção de matéria seca $\left(\mathrm{g} \mathrm{m}^{-2}\right)$ em relação às épocas de vedação e periodos de uso da parte aérea do Panicum maximum cv. Mombaça (média de quatro repetições).

\begin{tabular}{|c|c|c|c|c|c|}
\hline \multirow{2}{*}{$\begin{array}{l}\text { Épocas de } \\
\text { Vedação(1) }\end{array}$} & \multicolumn{4}{|c|}{ Períodos de Uso ${ }^{(2)}$} & \multirow[b]{2}{*}{ Média } \\
\hline & Junho & Julho & Agosto & Setembro & \\
\hline $10 / 03 / 1997$ & 171,23 & 161,53 & 210,03 & 187,58 & $182,59 a$ \\
\hline 24/03/1997 & 71,38 & 88,95 & 105,10 & 163,28 & $107,18 b$ \\
\hline 07/04/1997 & 52,43 & 86,63 & 122,98 & 132,23 & $98,56 \mathrm{~b}$ \\
\hline Média & $98,34 \mathrm{~B}$ & $112,37 \mathrm{E}$ & 146,03 & $161,03 \mathrm{~A}$ & \\
\hline
\end{tabular}

Médias seguidas da mesma letra não diferem significativamente entre si $(P>0,05)$ pelo teste de Tukey.

C.V. $(\%)^{(1)}=13,26$

C.V. $(\%)^{(2)}=22,75$

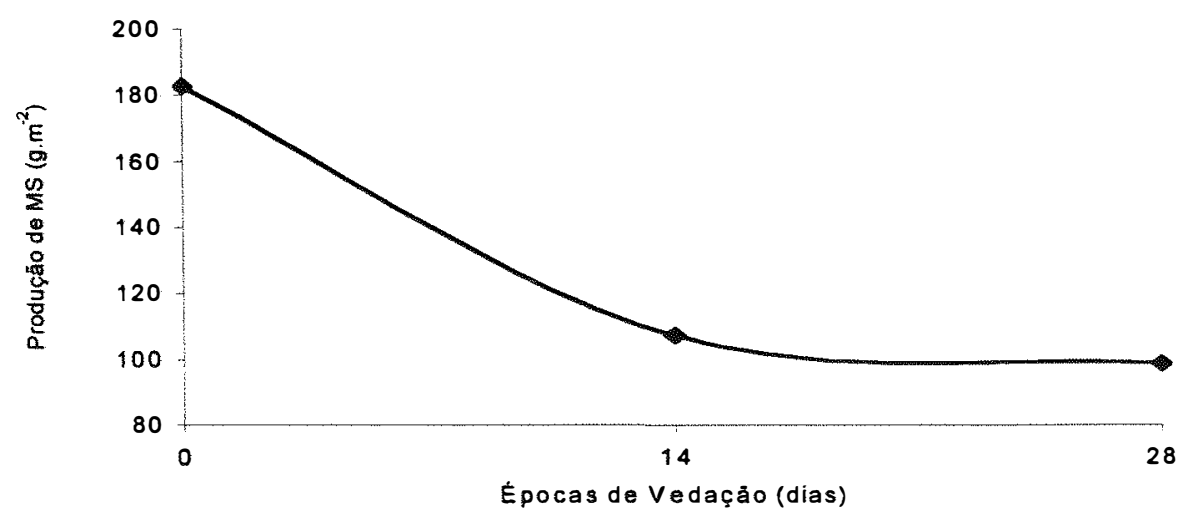

Figura 5. Produção de matéria seca $\left(g \cdot \mathrm{m}^{-2}\right)$ obtidas da parte aérea do Panicum maximum cv. Mombaça, em função das épocas de vedação, onde 0 corresponde a vedação realizada em 10/03/97, 14 corresponde a vedação realizada em 24/03/97 e 28 corresponde a vedação realizada em 07/04/97. 


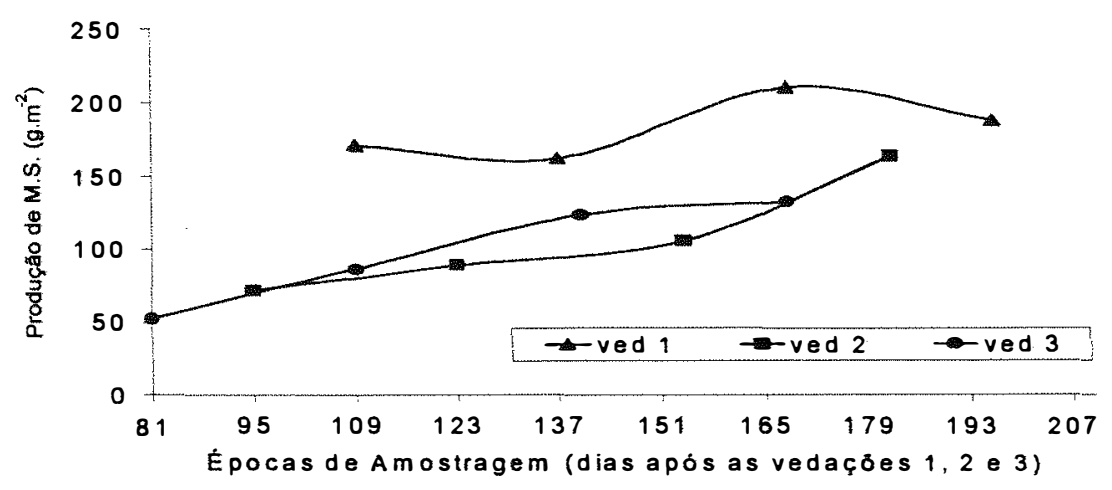

Figura 6. Produção de matéria seca $\left(\mathrm{g} \cdot \mathrm{m}^{-2}\right)$ obtida da parte aérea do Panicum maximum cv. Mombaça, em função dos periodos de uso avaliados épocas de amostragem (junho, julho, agosto e setembro), em dias após as vedações 1 (10/03/97), 2 (24/03/97) e 3 (07/04/97).

Os teores de MS para o Panicum maximum cv. Mombaça, (Tabela 5 e Figura 7) sofreram influência dos periodos de uso apresentando maiores teores, quando utilizouse a pastagem em agosto e setembro, devido ao crescimento da forrageira, com acúmulo de material senescente e perda de água à medida em que ocorre a maturidade. Para as diferentes vedações não foram observadas diferenças significativas entre si.

Tabela 5. Teores de matéria seca $\left(\mathrm{g} \mathrm{kg}^{-1}\right)$ em relação às vedações e periodos de uso utilizados da parte aérea do Panicum maximum cv. Mombaça (média de quatro repetições).

\begin{tabular}{|c|c|c|c|c|c|}
\hline Epocas de & & Período & Uso & & \\
\hline Vedação & Junho & Julho & Agosto & Setembro & Média \\
\hline 10/03/1997 & 393,60 & 410,38 & 505,95 & 475,13 & 446,26 ns \\
\hline $24 / 03 / 1997$ & 365,83 & 388,75 & 481,40 & 449,28 & 421,31 ns \\
\hline $07 / 04 / 1997$ & 350,43 & 384,08 & 523,75 & 472,50 & 432,69 ns \\
\hline Média & $369,95 \mathrm{D}$ & $394,40 \mathrm{C}$ & $503,70 \mathrm{~A}$ & $465,63 \mathrm{~B}$ & \\
\hline
\end{tabular}




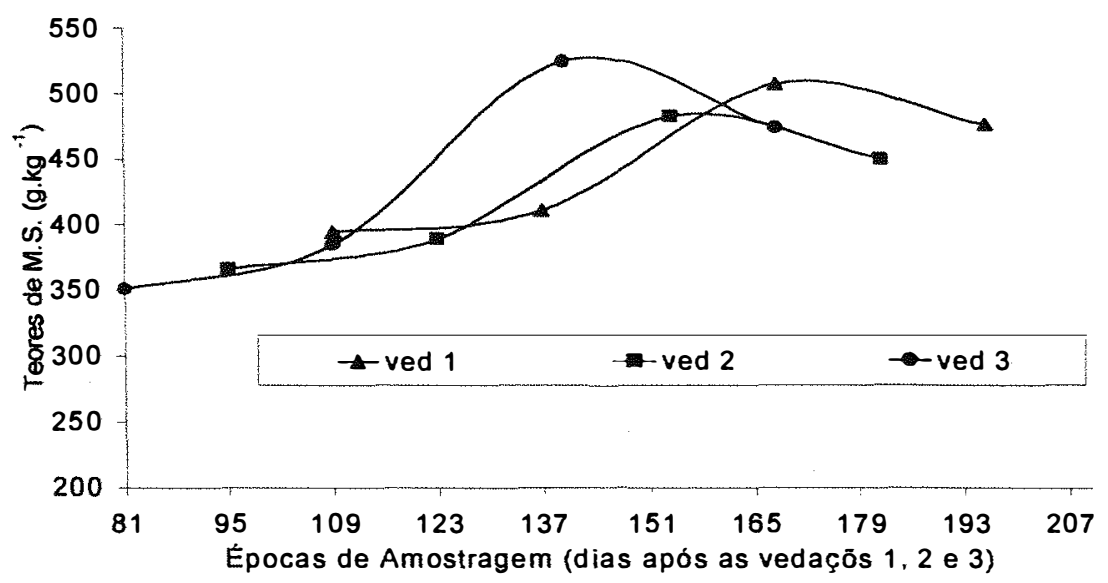

Figura 7. Teores de matéria seca $\left(\mathrm{g} . \mathrm{kg}^{-1}\right)$ obtida da parte aérea do Panicum maximum Cv. Mombaça, em função dos periodos de uso avaliados - épocas de amostragem (junho, julho, agosto e setembro), em dias após as vedações 1 (10/03/97), 2 (24/03/97) e $3(07 / 04 / 97)$.

\section{2 Composição bromatológica}

\section{2.1 Brachiaria brizantha cV. Marandu}

Os resultados da análise bromatológica e da digestibilidade "in vitro" estão apresentados nas Tabelas de 6 a 11. Os teores de proteína bruta (PB) variaram significativamente em função dos periodos de uso (Tabela 6 e Figura 8), apresentando maiores teores em torno de $60 \mathrm{~g}^{\mathrm{kg}}{ }^{-1}$, para as amostragens em junho ou setembro e vedação em 07/04. Ainda pela Tabela 6 observou-se valores médios máximos de $56,01 \mathrm{~g} \cdot \mathrm{kg}^{-1} ; 53,17 \mathrm{~g} \cdot \mathrm{kg}^{-1}$ e $52,80 \mathrm{~g} \cdot \mathrm{kg}^{-1}$ para junho, julho e setembro, respectivamente; superando apenas os teores de PB em agosto $\left(40,84 \mathrm{~g} \cdot \mathrm{kg}^{-1}\right)$, devido provavelmente à ausência de precipitação relatada nesse período, conferindo menores proporções de conteúdo celular. De acordo com Forbes (1995), em nenhum dos períodos utilizados para a avaliação da forrageira estudada durante o periodo de estiagem, foi atingida a concentração mínima de PB necessária para não haver redução no consumo voluntário, $120,00 \mathrm{~g} \cdot \mathrm{kg}^{-1}$ e $80,00 \mathrm{~g} \cdot \mathrm{kg}^{-1}$ para vacas na fase de lactação e bovinos de corte, sob mantença, respectivamente. Entre as épocas de vedação, a variável não apresentou diferenças significativas. 
Baseando-se nos dados da Tabela 6, os decréscimos diários (obtidos pelas médias das épocas de vedação) nos teores de PB para os períodos de junho/julho foram $0,152 \mathrm{~g} . \mathrm{kg}^{-1}$; para julho/agosto foram $0,354 \mathrm{~g} \cdot \mathrm{kg}^{-1}$ e para agosto/setembro foram verificados acréscimos de $0,342 \mathrm{~g} \cdot \mathrm{kg}^{-1}$, valores esses inferiores aos citados por Minson (1990) de 2,2 g. $\mathrm{kg}^{-1}$ para o decréscimo diário para forrageiras tropicais.

Tabela 6. Teores de proteína bruta - PB $\left(\mathrm{g} \mathrm{kg}^{-1}\right)$ da parte aérea da Brachiaria brizantha cv. Marandu em relação às épocas de vedação e períodos de uso utilizados (média de quatro repetições).

\begin{tabular}{llllll}
\hline $\begin{array}{l}\text { Épocas de } \\
\text { Vedação }\end{array}$ & \multicolumn{5}{c}{ Períodos de Uso } \\
\cline { 2 - 6 } & Junho & Julho & Agosto & Setembro & Média \\
\hline \multirow{2}{*}{$10 / 03 / 1997$} & 49,88 & 54,48 & 40,05 & 49,00 & $48,35 \mathrm{~ns}$ \\
$24 / 03 / 1997$ & 58,43 & 54,90 & 42,23 & 50,97 & $51,63 \mathrm{~ns}$ \\
$07 / 04 / 1997$ & 59,73 & 50,13 & 40,25 & 58,43 & $52,13 \mathrm{~ns}$ \\
& & & & & \\
\hline Média & $56,01 \mathrm{~A}$ & $53,17 \mathrm{~A}$ & $40,84 \mathrm{~B}$ & $52,80 \mathrm{~A}$ & \\
\hline
\end{tabular}

Médias seguidas da mesma letra não diferem significativamente entre si $(P>0,05)$ pelo teste de Tukey.ns $=$ não significativo $(P>0,05)$ pelo teste de Tukey.

C.V. $(\%)=11,63$

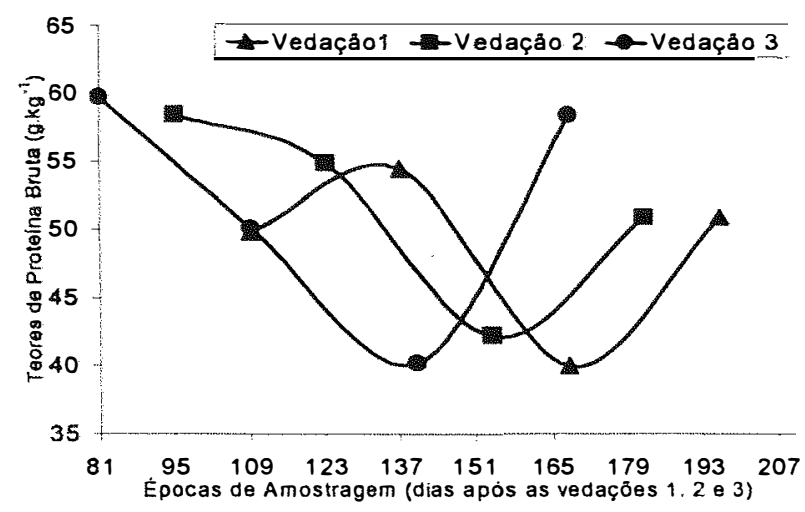

Figura 8 Teores de PB $\left(\mathrm{g}^{\mathrm{kg}} \mathrm{kg}^{-1}\right)$ obtida da parte aérea do Brachiaria brizantha cv. Marandu, em função dos períodos de uso avaliados - épocas de amostragem (junho, julho, agosto e setembro), em dias após as vedações 1 (10/03/97), 2 (24/03/97) e $3(07 / 04 / 97)$. 
De acordo com Minson (1992) a diminuição nos teores de PB ocorrem devido à maior proporção de hastes, com avanço da maturidade, as quais apresentam concentração protéica inferior às das folhas, além de diminuição na PB das folhas e hastes. Silva et al. (1987), trabalhando com gramineas subtropicais e temperadas, entre elas o capim bermuda (Cynodon dactylon), relataram que temperaturas mais elevadas, aumentam a taxa de crescimento de colmos, independente do fotoperiodo testado variar de 9 ou $12 \mathrm{~h}$. Da mesma maneira, Deinum et al. (1976), estudaram os efeitos de diferentes temperaturas na produção e composição química de Brachiaria ruziziensis e Setaria sphacelata, onde temperaturas elevadas $\left(31 / 27^{\circ} \mathrm{C}\right.$, dia e noite respectivamente), estimularam o desenvolvimento das plantas, resultando em menores digestibilidades da matéria orgânica e conteúdos de proteína bruta nas folhas e colmos.

Costa et al. (1993), observaram diminuições nos teores de PB de $84,46 \mathrm{~g}^{\mathrm{kg}} \mathrm{g}^{-1}$ para 71,60 g. $\mathrm{kg}^{-1}$ quando a vedação foi realizada em abril ou fevereiro, respectivamente, e reduções de $90,50 \mathrm{~g} \cdot \mathrm{kg}^{-1}$ para $67,80 \mathrm{~g} \cdot \mathrm{kg}^{-1}$ quando o período de uso passou de junho para setembro, para Brachiaria brizantha cv. Marandu .

$A$ análise de variância revelou interação entre épocas de vedação e periodos de uso para a variável FDA (fibra em detergente ácido), conforme apresentado na Tabela 7 e Figuras 9 e 10.

As vedações em 24/03 e 07/04 proporcionaram maiores teores de FDA, quando amostradas em junho. Por outro lado, a vedação em 10/03, proporcionou os menores teores de FDA, devido provavelmente aos menores teores de lignina. Independentemente das épocas de vedação utilizadas, os períodos de uso em junho com maior participação da lignina, proporcionaram maiores teores de FDA em relação às outras épocas de amostragens, não diferindo apenas do período de uso em julho com vedação em 07/04, demonstrando dessa forma que a FDA não aumentou com o avanço do estádio de maturação da forrageira, assim como não ocorreu lignificação da forrageira com a maturidade (Figuras 9 e 10). Esse comportamento pode ser provavelmente explicado, devido à dinâmica do crescimento das forrageiras tropicais à campo, onde observa-se o padrão sigmóide de crescimento dessas plantas, conferindo ao período de uso em junho, maiores teores de fibra, devido à pouca rebrota de material verde, ou seja, esse material amostrado em junho, apresenta-se mais velho e de qualidade inferior aos materiais amostrados nos demais períodos de uso, que 
tiveram a oportunidade de rebrotar mais vezes, portanto apresentam-se como materiais mais jovens e de melhor qualidade. A senescência observada na Figura 11, principalmente para os períodos de uso em agosto e setembro e de acordo com a Figura 1, provavelmente ocorreu devido às condições climáticas observadas como ausência de precipitação em agosto e temperaturas mais elevadas em agosto e setembro (em tomo de $40^{\circ} \mathrm{C}$ ), caracterizando um material morto jovem, com menor acúmulo de material verde novo (Corsi ${ }^{1}$ ).

Tabela 7. Teores de fibra em detergente ácido - FDA $\left(\mathrm{g} \mathrm{kg}^{-1}\right)$ da parte aérea da Brachiaria brizantha cv. Marandu em relação às épocas de vedação e períodos de uso utilizados (média de quatro repetições).

\begin{tabular}{|c|c|c|c|c|c|c|c|}
\hline \multirow{2}{*}{$\begin{array}{l}\text { Epocas de } \\
\text { Vedação(1) }\end{array}$} & \multicolumn{7}{|c|}{ Períodos de Uso ${ }^{(2)}$} \\
\hline & Junho & Julho & & Agosto & & Setembro & \\
\hline $10 / 03 / 97$ & $328,25 \mathrm{~A} \mathrm{~b}$ & 313,23 & $\mathrm{Ba}$ & 303,93 & $\mathrm{~B} \mathrm{a}$ & 310,45 & $\mathrm{~B} \mathrm{a}$ \\
\hline $24 / 03 / 97$ & $354,00 \mathrm{~A} \mathrm{a}$ & 311,90 & $\mathrm{~B}$ a & 299,75 & $\mathrm{~B}$ a & 306,70 & $\mathrm{~B}$ a \\
\hline $07 / 04 / 97$ & $338,35 \quad \mathrm{~A} a b$ & 319,10 & $A B a$ & 309,45 & $\mathrm{~B}$ a & 313,63 & $\mathrm{~B}$ a \\
\hline
\end{tabular}

Médias seguidas da mesma letra, maiúscula na linha $e$ minúscula na coluna, não diferem significativamente entre si $(P>0,05)$ pelo teste de Tukey.

C.V.(\%) ${ }^{(1)}=2,92$

C.V. $(\%)^{(2)}=2,78$

Wilson et al. (1991), trabalhando com Cynodon dactylon, Panicum maximum var. trichoglume, Panicum laxum, Lolium perenne e Medicago sativa, encontraram que altas temperaturas diminuíram a digestibilidade da matéria orgânica em média $6,6 \%$ nas folhas e $12,4 \%$ nos caules para as gramíneas avaliadas e 2,6\% em folhas e caules de Medicago sativa. Ressaltando que a diminuição na digestibilidade da matéria orgânica e digestibilidade da parede celular ocorreu em virtude de altas temperaturas diurnas e noturnas $\left(32 / 26^{\circ} \mathrm{C}\right.$ respectivamente), correlacionadas com elevadas concentrações de lignina, diminuindo também o grau de digestão de células esquerenquemáticas, dos feixes vasculares e da bainha vascular.

Da mesma maneira, os conteúdos de FDN (Fibra em detergente neutro), (Tabela 8 e Figuras 9 e 10) foram maiores para a época de vedação em 10/03 e

\footnotetext{
${ }^{1}$ CORSI, M. Comunicação pessoal, 1999.
} 
apresentaram em relação aos períodos de uso avaliados (Figura 10) teores mais elevados de FDN quando a pastagem foi utilizada em junho. Resultados diferentes foram encontrados em Arroyo-Aguilú e Coward-Lord (1974) que observaram maior correlação entre a idade de corte e a concentração de FDA, do que idade de corte e concentração de FDN. 
(a)

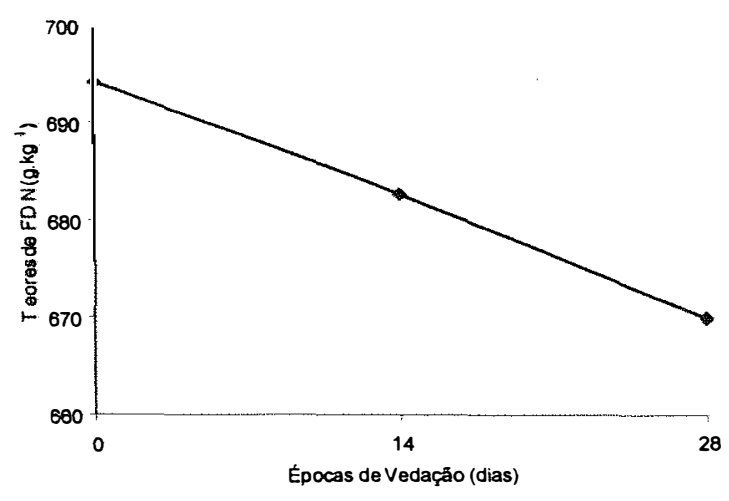

(c)

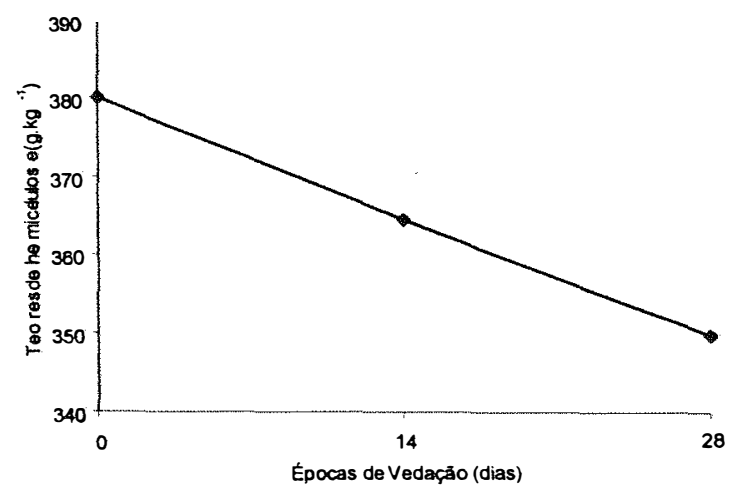

(e)

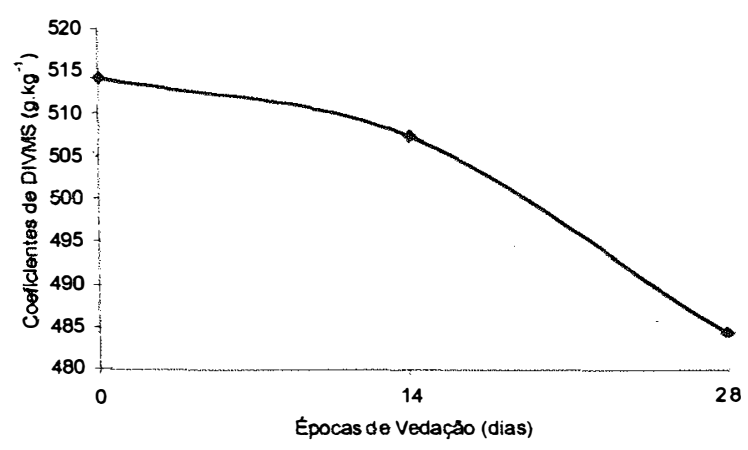

(b)

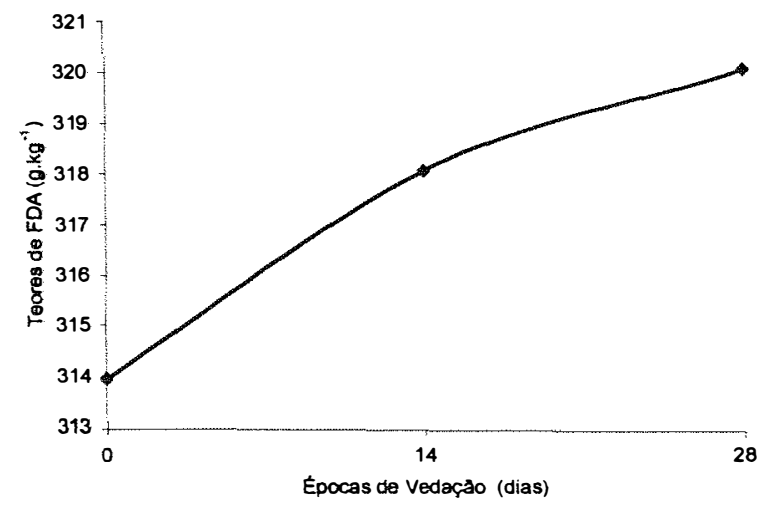

(d)

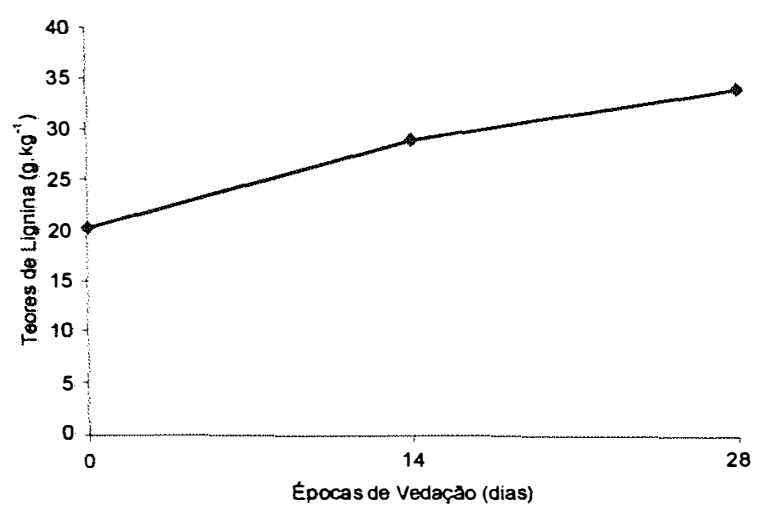

Figura 9. Teores de FDN (a), FDA (b), hemicelulose (c), lignina (d) e DIVMS (e) ( $\left(\mathrm{g} \cdot \mathrm{kg}^{-1}\right)$, obtidos da parte aérea da Brachiaria brizantha cv. Marandu, para as épocas de vedação, onde 0,14 e 28 correspondem as vedações realizadas em 10/03/97, 24/03/97 e 07/04/97, respectivamente. 
Tabela 8. Teores de fibra em detergente neutro - FDN $\left(\mathrm{g} \mathrm{kg}^{-1}\right)$ da parte aérea da Brachiaria brizantha cv. Marandu em relação às épocas de vedação e períodos de uso utilizados (média de quatro repetições).

\begin{tabular}{llllll}
\hline Épocas de & \multicolumn{5}{c}{ Períodos de Uso(2) } \\
\cline { 2 - 6 } Vedação(1) & Junho & Julho & Agosto & Setembro & Média $^{(1)}$ \\
\hline 10/03/1997 & 711,63 & 692,30 & 680,98 & 691,55 & $694,12 \mathrm{a}$ \\
$24 / 03 / 1997$ & 713,98 & 675,63 & 662,80 & 678,15 & $682,64 \mathrm{~b}$ \\
$07 / 04 / 1997$ & 677,68 & 670,80 & 662,80 & 668,48 & $669,94 \mathrm{C}$ \\
& & & & \\
\hline Média $^{(2)}$ & $701,09 \mathrm{~A}$ & $679,58 \mathrm{~B}$ & $668,86 \mathrm{~B}$ & $679,40 \mathrm{~B}$ & \\
\hline
\end{tabular}

Médias seguidas da mesma letra não diferem significativamente entre si $(P>0,05)$ pelo teste de Tukey.

C.V. $(\%)^{(1)}=1,19$

C.V. $(\%)^{(2)}=1,57$ 
(a)

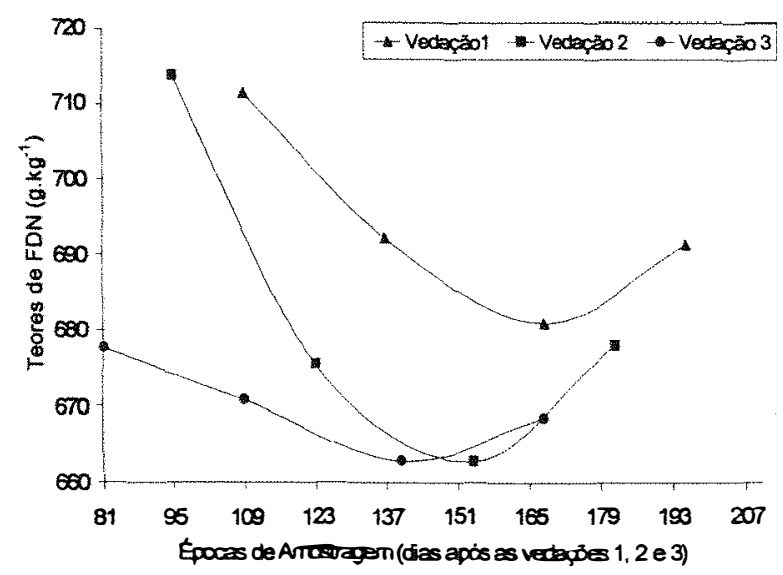

(c)

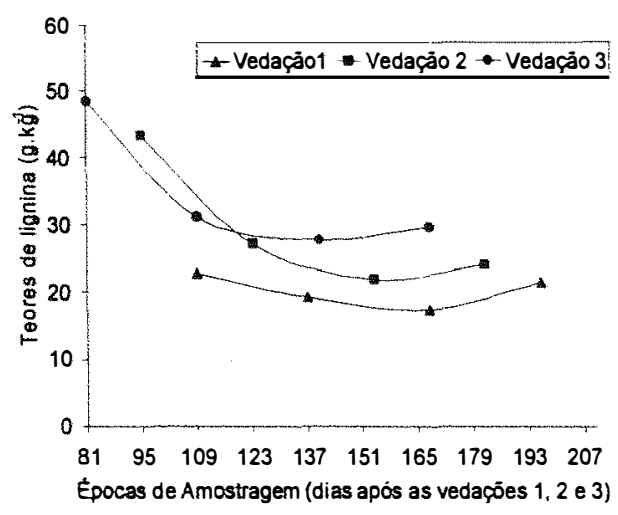

(b)

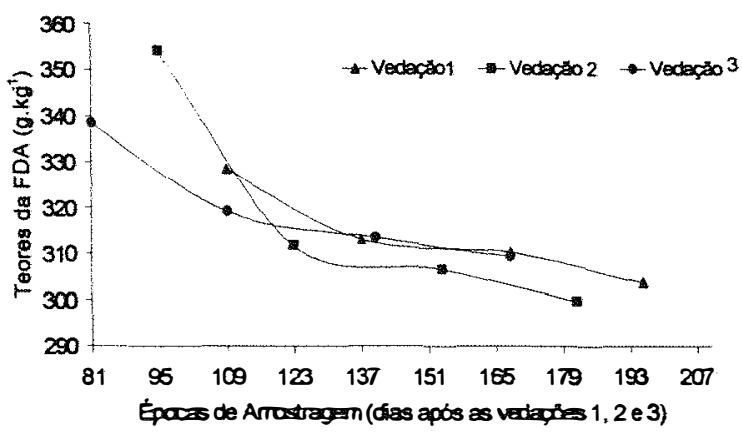

(d)

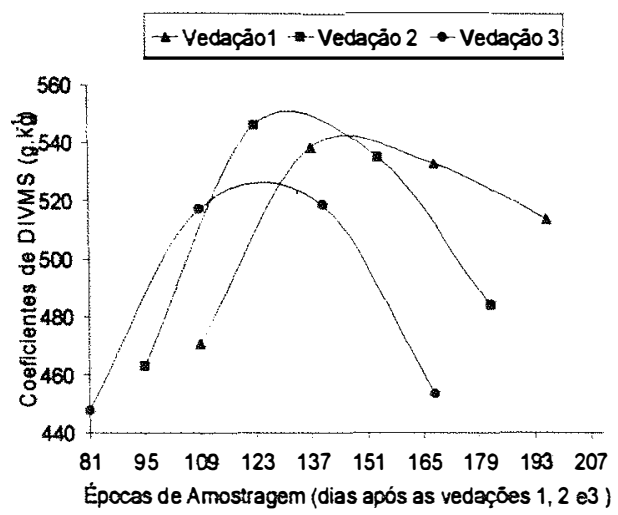

Figura 10. Teores de FDN (a), FDA (b), lignina (c) e coeficientes de DIVMS (d), em g. $\mathrm{kg}^{-1}$, obtidos da parte aérea da Brachiaria brizantha cv. Marandu, em função dos períodos de uso avaliados - épocas de amostragem (junho, julho, agosto e setembro), em dias após as vedações 1 (10/03/97), 2 (24/03/97) e 3 (07/04/97). 
(a)

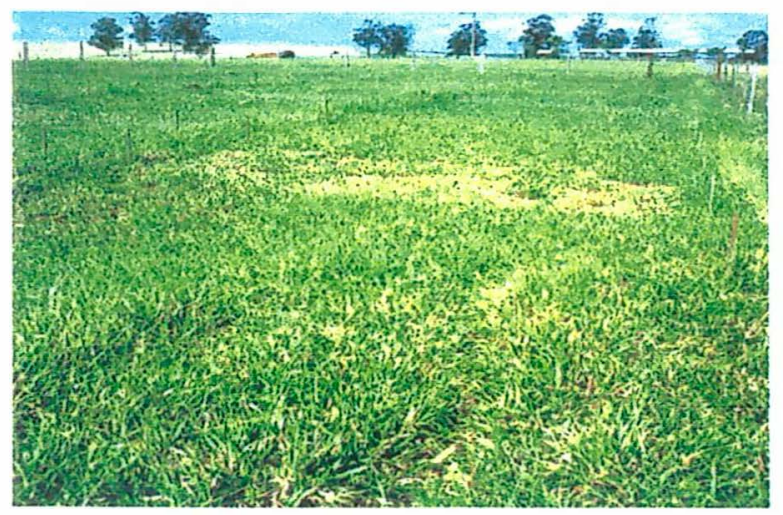

(c)

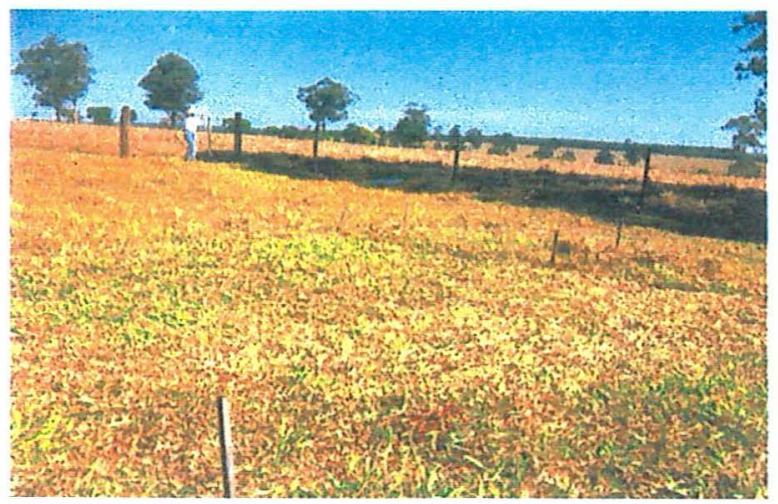

(b)

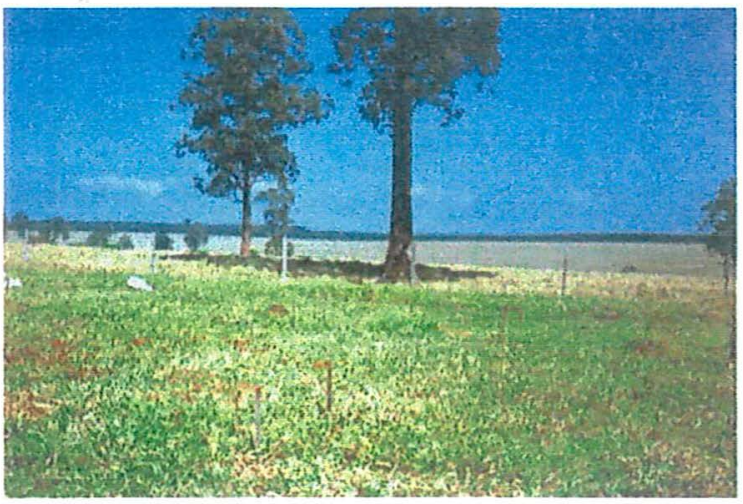

(d)

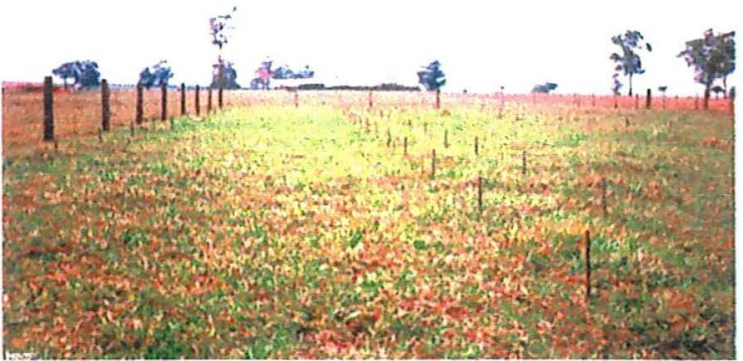

Figura 11 Períodos de uso para a Brachiaria brizantha cv. Marandu, onde a pastagem foi amostrada em: (a) junho; (b) julho; (c) agosto e (d) setembro. 
A variável hemicelulose (Tabela 9) decresceu linearmente somente com as épocas de vedação, demostrando a participação dessa variável nas épocas de vedação para as frações FDA e FDN (Tabelas 7 e 8), com maiores coeficientes de DIVMS e menores proporções de lignina. (Tabelas 10 e 11).

Tabela 9. Teores de hemicelulose $\left(\mathrm{g} \mathrm{kg}^{-1}\right)$ da parte aérea da Brachiaria brizantha cV. Marandu em relação às épocas de vedação e períodos de uso utilizados (média de quatro repetições).

\begin{tabular}{llllll}
\hline $\begin{array}{l}\text { Epocas de } \\
\text { Vedação }\end{array}$ & \multicolumn{5}{c}{ Períodos de Uso } \\
\cline { 2 - 6 } & Junho & Julho & Agosto & Setembro & Média \\
\hline 10/03/1997 & 383,40 & 379,08 & 377,05 & 381,10 & $380,16 \mathrm{a}$ \\
$24 / 03 / 1997$ & 359,98 & 363,75 & 363,10 & 371,45 & $364,57 \mathrm{~b}$ \\
$07 / 04 / 1997$ & 339,35 & 351,70 & 353,35 & 354,93 & $349,84 \mathrm{c}$ \\
& & & & \\
\hline Média & $360,91 \mathrm{~ns}$ & $364,84 \mathrm{~ns}$ & $364,50 \mathrm{~ns}$ & $369,16 \mathrm{~ns}$ & \\
\hline
\end{tabular}

Médias seguidas da mesma letra não diferem significativamente entre si $(P>0,05)$ pelo teste de Tukey. ns $=$ não significativo $(P>0,05)$ pelo teste de Tukey.

C.V. $(\%)=0,94$

Tabela 10. Coeficientes de digestibilidade "in vitro" da matéria seca - DIVMS $\left(\mathrm{g} \mathrm{kg}^{-1}\right)$ da parte aérea da Brachiaria brizantha cv. Marandu em relação às épocas de vedação e períodos de uso utilizados (média de quatro repetições).

\begin{tabular}{llllll}
\hline \multirow{2}{*}{$\begin{array}{l}\text { Epocas de } \\
\text { Vedação }\end{array}$} & \multicolumn{5}{c}{ Períodos de Uso } \\
\cline { 2 - 6 } & Junho & Julho & Agosto & Setembro & Média \\
\hline 10/03/1997 & 470,65 & 538,15 & 532,70 & 513,53 & $513,76 \mathrm{a}$ \\
$24 / 03 / 1997$ & 463,03 & 545,90 & 534,85 & 483,93 & $506,93 \mathrm{ab}$ \\
$07 / 04 / 1997$ & 447,53 & 517,05 & 518,43 & 453,23 & $484,06 \mathrm{~b}$ \\
& & & & \\
\hline Média & $460,40 \mathrm{~B}$ & $533,70 \mathrm{~A}$ & $528,66 \mathrm{~A}$ & $483,56 \mathrm{~B}$ & \\
\hline
\end{tabular}

Médias seguidas da mesma letra não diferem significativamente entre si $(P>0,05)$ pelo teste de Tukey. C.V. $(\%)^{(1)}=4,91$

C.V.(\%) ${ }^{(2)}=4,62$ 
Tabela 11. Teores de lignina $\left(\mathrm{g} \mathrm{kg}^{-1}\right)$ da parte aérea da Brachiaria brizantha cv. Marandu em relação às épocas de vedação e períodos de uso utilizados (média de quatro repetições).

\begin{tabular}{llllll}
\hline $\begin{array}{l}\text { Épocas de } \\
\text { Vedação(1) }\end{array}$ & \multicolumn{5}{c}{ Períodos de Uso ${ }^{(2)}$} \\
\cline { 2 - 6 } & Junho & Julho & Agosto & Setembro & Média \\
\hline \multirow{2}{*}{$10 / 03 / 1997$} & 22,88 & 19,30 & 17,50 & 21,63 & $20,33 \mathrm{~b}$ \\
$24 / 03 / 1997$ & 43,35 & 27,25 & 22,00 & 24,23 & $29,21 \mathrm{ab}$ \\
$07 / 04 / 1997$ & 48,40 & 31,28 & 27,85 & 29,78 & $34,33 \mathrm{a}$ \\
& & & & & \\
\hline Média & $38,21 \mathrm{~A}$ & $25,94 \mathrm{~B}$ & $22,45 \mathrm{~B}$ & $25,21 \mathrm{~B}$ &
\end{tabular}

Médias seguidas da mesma letra não diferem significativamente entre si $(P>0,05)$ pelo teste de Tukey.

C. ${ }^{(1)}(\%)=29,37$

C.V. ${ }^{(2)}(\%)=24,60$

Os autores Buxton e Redfearn (1997), descreveram reduções de digestibilidade da fibra, em virtude da lignificação da mesma. Para Van Soest (1994), existe correlação entre digestibilidade e concentração de FDN digestivel (fração digestivel da fibra: hemicelulose e celulose elevadas) encontradas nas forrageiras. Segundo Eastridge (1997), a fração FDN está correlacionada com o enchimento ruminal e ingestão de MS.

Pela Tabela 10 e Figura 9, observou-se variações significativas entre as épocas de vedação para os coeficientes de DIVMS (digestibilidade "in vitro" da matéria seca), os quais apresentaram maiores digestibilidades na primeira época de vedação $(513,76$ g. $\mathrm{kg}^{-1}$ ), decrescendo ao longo do tempo, sem diferenças significativas da época de vedação no final de março $\left(506,93 \mathrm{~g} \cdot \mathrm{kg}^{-1}\right)$. Por outro lado, a vedação no início de abril apresentou os menores coeficientes de DIVMS (484,06 g. $\left.\mathrm{kg}^{-1}\right)$ sem variar significativamente da segunda época. Para as épocas de uso, observou-se a tendência mostrada na Figura 10, com julho e agosto de maneira geral, apresentando maiores coeficientes de DIVMS, enquanto que em junho os coeficientes foram menores, demonstrando o efeito da correlação inversa da digestibilidade em relação ao conteúdo de parede celular, comprovando reduções na digestibilidade, pela fração lignina ser indigestível como verificados na Figura 10. 
Arroyo-Aguilú e Coward-Lord (1974), ao avaliarem dez forrageiras tropicais, encontraram correlação negativa entre maturidade da forrageira e teores de lignina. Entretanto, isso não foi verificado para a Brachiaria brizantha cv. Marandu, uma vez que o corte da forrageira no começo da estação seca proporcionou quantidades mais elevadas de lignina (Figura 1). Intensidades luminosas menores e temperaturas mais elevadas parecem ocasionar maior acúmulo de lignina em gramíneas forrageiras tropicais. Ford et al. (1979) testaram a influência dos efeitos da temperatura sob o conteúdo de parede celular, absorção de lignina e digestibilidade "in vitro" da MS de treze gramíneas tropicais e onze gramineas temperadas, alternando temperaturas diurnas e noturnas, encontrando de maneira geral, maiores acúmulos de parede celular quando as gramineas tropicais receberam temperaturas de $21 / 13^{\circ} \mathrm{C}$ (diurna e noturna respectivamente), enquanto que gramíneas temperadas apresentaram maiores acúmulos de parede celular em temperaturas mais elevadas $32 / 24^{\circ} \mathrm{C}$ (diurna e noturna respectivamente), relatando que as gramineas de maneira geral, apresentaram correlação negativa entre conteúdos de lignina (fibra indigestivel) e digestibilidade, com efeitos muito mais marcantes nas temperaturas mais elevadas e em gramíneas tropicais.

Em experimento similar, Fales (1986) obteve aumentos na parede celular (FDN indigestivel) quando as temperaturas foram crescentes, passando de $13 / 10^{\circ} \mathrm{C}$ para $30 / 27^{\circ} \mathrm{C}$ (diurna/ noturna), com diminuição na fração de FDN digestivel, para Festuca arundinacea.

De maneira geral verificou-se nas vedações estudadas que os valores de FDA e lignina, encontrados nas Tabelas 7 e 11 respectivamente, apresentaram variação linear decrescente, com menores valores para a pastagem vedada mais precocemente (10/03) face à pastagem vedada mais tardiamente (07/04); enquanto que as variáveis FDN, hemicelulose e DIVMS (Tabelas 8, 9 e 10) apresentaram variação linear crescente, demonstrando dessa forma que conteúdos mais elevados em FDN e hemicelulose e menores em lignina contribuíram para maiores coeficientes de DIVMS para a época de vedação em 10/03 (Figura 9).

Segundo Moore e Mott (1973), um coeficiente de DIVMS inferior a 650,00 g. $\mathrm{kg}^{-1}$ limitaria consumo; entretanto, para Milford e Haydock (1965), 490,00 g. $\mathrm{kg}^{-1}$ de DIVMS, são suficientes para bovinos a pasto em gramíneas tropicais, como os verificados nos períodos de uso em julho e agosto, para o pasto vedado em 24/03 ou 07/04, e julho, 
agosto e setembro, quando o pasto foi vedado em $10 / 03$ (acima de $500 \mathrm{~g} \cdot \mathrm{kg}^{-1}$ ) (Tabela 10 e Figura 10) para a Brachiaria brizantha cv. Marandu. Foram verificados acréscimos médios diários na DIVMS de $2,44 \mathrm{~g} \cdot \mathrm{kg}^{-1}$ para o periodo junho/julho e reduções de 1,5 $\mathrm{g} . \mathrm{kg}^{-1}$ para agosto/setembro, permanecendo o período de julho/agosto sem diferenças significativas nesta variável. Costa et al. (1993), observaram coeficientes de DIVMS (obtidos na fração verde de Brachiaria brizantha cv. Marandu) de $606,00 \mathrm{~g}^{\mathrm{kg}}{ }^{-1}$ para periodo de uso em junho a $485,00 \mathrm{~g} . \mathrm{kg}^{-1}$ para uso em setembro, vedando o pasto em fevereiro, março ou abril. Minson (1971), estimou declínio diário na digestibilidade de gramíneas forrageiras ao redor de $1,0 \mathrm{~g} \cdot \mathrm{kg}^{-1}$. $\mathrm{O}$ decréscimo na digestibilidade com o aumento da idade de corte, sob pastejo, foi observado por Pedreira (1995); diminuição essa devido ao acréscimo no conteúdo de parede celular, aumentando os conteúdos de FDN, com provável lignificação da fibra.

De acordo com Van Soest (1994), a fibra interfere na digestibilidade devido a sua associação com a lignina. Entretanto, a fração FDN observada para as vedações apresentou-se possivelmente associada proporcionalmente a conteúdos de hemicelulose; o que permite a caracterização como FDN digestivel (Tabelas 8 e 9 e Figura 9).

\section{2. 2 Panicum maximum cv. Mombaça}

Os resultados da análise bromatológica e da digestibilidade "in vitro" estão apresentados nas Tabelas de 12 a 17. Os teores de PB e DIVMS do Panicum maximum cv. Mombaça são encontradas nas Tabelas 12 e 13, onde verificou-se significância para as diferentes amostragens avaliadas, com maiores teores de PB quando a forrageira foi amostrada em junho, ultrapassando $70 \mathrm{~g} . \mathrm{kg}^{-1}$, atingindo segundo Milford e Haydock (1965) a concentração mínima de PB (70 g. $\left.\mathrm{kg}^{-1}\right)$ necessária para mantença de bovinos a pasto. Entretanto, os coeficientes médios de DIVMS para esse período de uso foram mínimos $\left(464,47 \mathrm{~g} . \mathrm{kg}^{-1}\right)$ e inferiores ao valor mínimo sugerido pelos mesmos autores, de $490,00 \mathrm{~g}^{\mathrm{kg}}{ }^{-1}$. Para os demais teores de PB, os valores médios para os periodos de uso em julho $\left(65,25 \mathrm{~g} \cdot \mathrm{kg}^{-1}\right)$ e agosto $\left(60,50 \mathrm{~g} \cdot \mathrm{kg}^{-1}\right)$, não diferiram estatisticamente de setembro $\left(59,30 \mathrm{~g} \mathrm{~kg}^{-1}\right)$, ficando, entretanto, abaixo dos preconizados pelos autores acima. 
Tabela 12. Teores de proteina bruta - PB $\left(\mathrm{g} \mathrm{kg}^{-1}\right)$ da parte aérea do Panicum maximum cv. Mombaça em relação às épocas de vedação e períodos de uso (média de quatro repetições).

\begin{tabular}{llllll}
\hline Épocas de & \multicolumn{5}{c}{ Períodos de Uso } \\
\cline { 2 - 6 } Vedação & Junho & Julho & Agosto & Setembro & Média \\
\hline $10 / 03 / 1997$ & 73,73 & 57,78 & 56,30 & 55,55 & $60,84 \mathrm{~ns}$ \\
$24 / 03 / 1997$ & 79,85 & 67,40 & 61,80 & 59,95 & $67,25 \mathrm{~ns}$ \\
$07 / 04 / 1997$ & 79,33 & 70,65 & 63,40 & 62,38 & $68,94 \mathrm{~ns}$ \\
\hline
\end{tabular}

\begin{tabular}{lllll}
\hline Média & $77,63 \mathrm{~A}$ & $65,28 \mathrm{~B}$ & $60,50 \mathrm{~B}$ & $59,30 \mathrm{BC}$
\end{tabular}

Médias seguidas da mesma letra não diferem significativamente entre si $(P>0,05)$ pelo teste de Tukey. ns $=$ não significativo $(P>0,05)$ pelo teste de Tukey. C.V. $(\%)=10,08$

Costa (1984) avaliou diversas forrageiras tropicais, encontrando maiores teores de PB em junho $\left(85,80 \mathrm{~g} \cdot \mathrm{kg}^{-1}\right)$ e menores em setembro $\left(59,20 \mathrm{~g} \cdot \mathrm{kg}^{-1}\right)$, relatando que gramíneas de Panicum maximum cv. Comum e cv. Tobiatã apresentaram teores de PB de $81,20 \mathrm{~g} \cdot \mathrm{kg}^{-1} \mathrm{e} 69,20 \mathrm{~g} \cdot \mathrm{kg}^{-1}$, respectivamente (médias das amostragens em junho, julho, agosto e setembro).

Alcântara et al. (1981), descreveram para Panicum maximum cv. Colonião, teores de: PB de 63,50 g. $\mathrm{kg}^{-1}$, FB de 318,20 g. $\mathrm{kg}^{-1}$ e DIVMS de 302,90 g. $\mathrm{kg}^{-1}$ (média de cortes executados no outono e inverno).

A DIVMS, apresentou valores superiores aos de junho para os demais periodos de uso, atingindo digestibilidades superiores à $550,00 \mathrm{~g} \cdot \mathrm{kg}^{-1}$ (Tabela 13 e Figura 12). Ao analisar-se a Figura 12, verificou-se que os teores de lignina apresentaram maior acúmulo para o mês de junho, estando inversamente correlacionados com os coeficientes de DIVMS. Estes resultados indicam que a digestibilidade de gramíneas forrageiras tropicais está provavelmente inversamente correlacionada com os teores de fibra indigestivel existentes na parede celular das plantas e não somente com o conteúdo celular (PB). No entanto, o fato de maiores teores de lignina serem encontrados no começo do período de inverno, pode possivelmente ser explicado em virtude de menor (pouca) rebrota da forrageira nesse periodo, caracterizando esse material, como um material mais velho (apesar de verde) e de pior qualidade, apresentando maiores proporções de fibra, devido à dinâmica do crescimento das forrageiras tropicais a campo, perfazendo a curva sigmóide de crescimento. Por outro lado, os períodos de uso realizados mais no final do período seco, apresentaram 
menores proporções de fibra indigestivel (lignina), por apresentarem mais rebrotas, ou seja, caracterizando um material mais novo e de melhor qualidade, apesar de estar mais senescente, como apresentam as Figura 1 e 13, provavelmente devido às condições climáticas favoráveis ao acúmulo de material senescente, como ausência de precipitação em agosto e temperaturas elevadas em agosto e setembro, aproximadamente $40^{\circ} \mathrm{C}\left(\mathrm{Corsi}^{2}\right)$.

Tabela 13. Coeficientes de digestibilidade "in vitro" da matéria seca - DIVMS $\left(\mathrm{g} \mathrm{kg}^{-1}\right) \mathrm{da}$ parte aérea do Panicum maximum cv. Mombaça em relação às épocas de vedação e períodos de uso (média de quatro repetições).

\begin{tabular}{llllll}
\hline $\begin{array}{l}\text { Épocas de } \\
\text { Vedação }\end{array}$ & \multicolumn{5}{c}{ Períodos de Uso } \\
\cline { 2 - 5 } & Junho & Julho & Agosto & Setembro & Média \\
\hline 10/03/1997 & 446,83 & 527,98 & 543,93 & 560,35 & $519,77 \mathrm{~ns}$ \\
$24 / 03 / 1997$ & 466,28 & 596,25 & 607,28 & 556,08 & $556,47 \mathrm{~ns}$ \\
$07 / 04 / 1997$ & 480,30 & 585,10 & 597,85 & 567,80 & $557,76 \mathrm{~ns}$ \\
\hline Média & $464,47 \mathrm{~B}$ & $569,78 \mathrm{~A}$ & $583,02 \mathrm{~A}$ & $561,41 \mathrm{~A}$ &
\end{tabular}

Médias seguidas da mesma letra não diferem significativamente entre si $(P>0,05)$ pelo teste de Tukey. ns $=$ não significativo $(P>0,05)$ pelo teste de Tukey.

C.V. $(\%)=5,05$

Ainda em relação às características climáticas, Senanayake (1995), no Sri Lanka testaram quatro gramíneas forrageiras tropicais nativas: Axonopus compressus, Imperata cylindrica, Cynodon dactylon e Pennisetum polystachyon em três niveis de intensidade luminosa ( $100 \%, 64 \%$ e $28 \%$ ), verificando em todas as espécies, aumentos na composição química: FDA, FDN, lignina, celulose e reduções nos coeficientes de DIVMS, onde os maiores acúmulos na parede celular foram encontrados com a diminuição na transmissão luminosa, com conteúdos de FDA e FDN aumentando em torno de $2 \%$ e os de lignina e celulose em torno de $1 \%$, com $28 \%$ de luz. Por outro lado, os coeficientes de DIVMS diminuíram em tomo de $3 \%$ com o mesmo nível de intensidade luminosa.

\footnotetext{
${ }^{2}$ CORSI, M. Comunicação pessoal, 1999.
} 
(a)

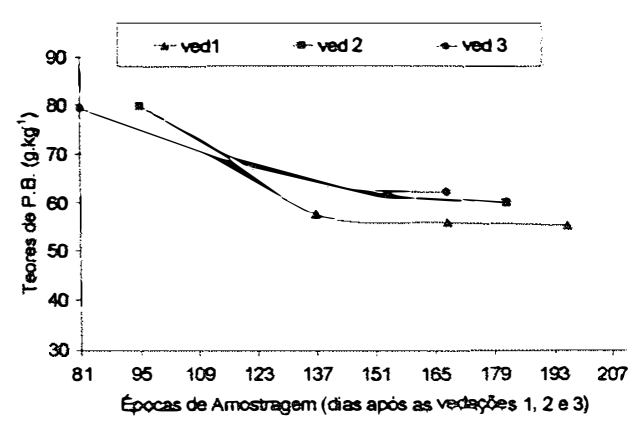

(c)

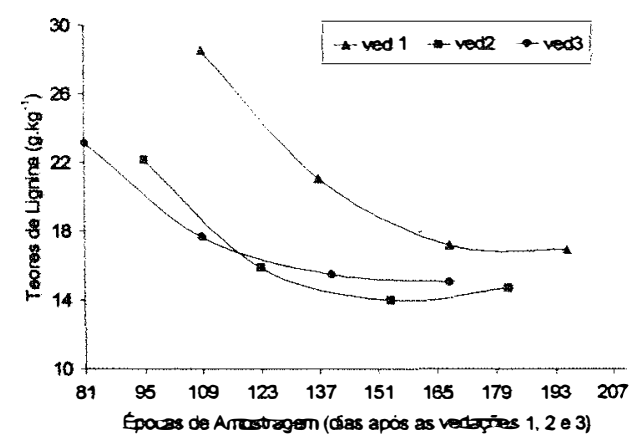

(b)

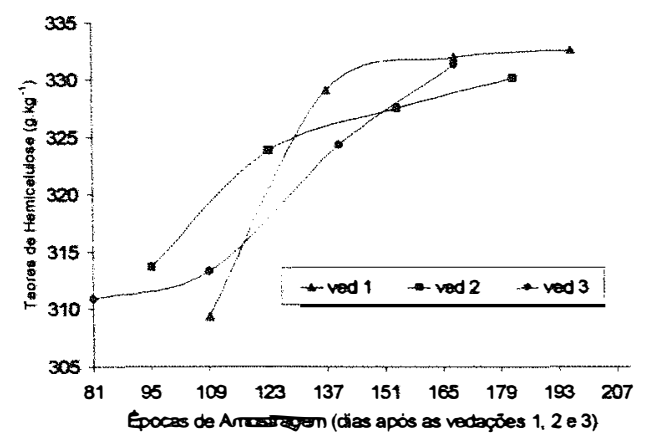

(d)

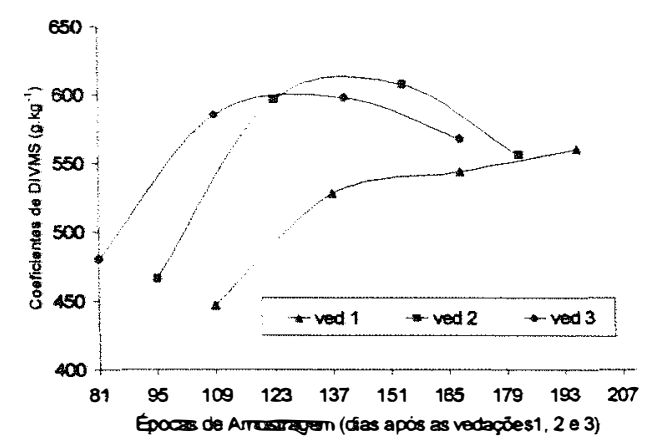

Figura 12. Teores de PB (a), hemicelulose (b), lignina (c) e DIVMS (d) (g.kg-1), obtidos da parte aérea do Panicum maximum cv. Mombaça, em função dos períodos de uso avaliados - épocas de amostragem (junho, julho, agosto e setembro), em dias após as vedações 1 (10/03/97), $2(24 / 03 / 97)$ e 3 (07/04/97). 
$(a)^{\star}$

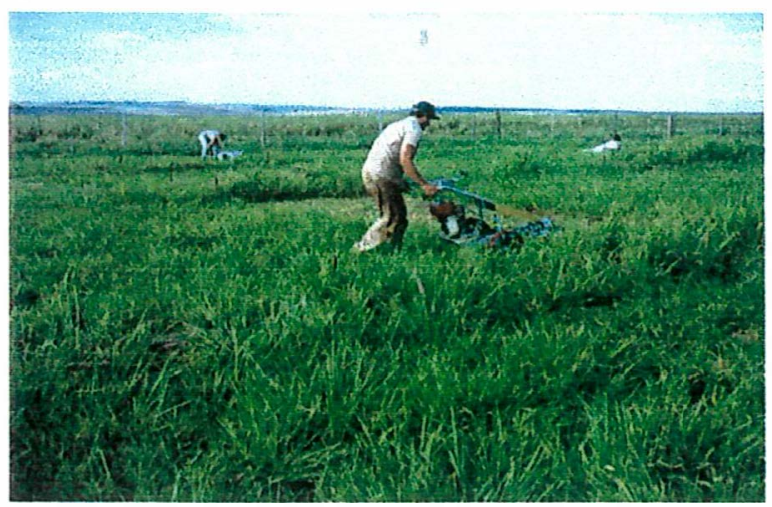

(c)

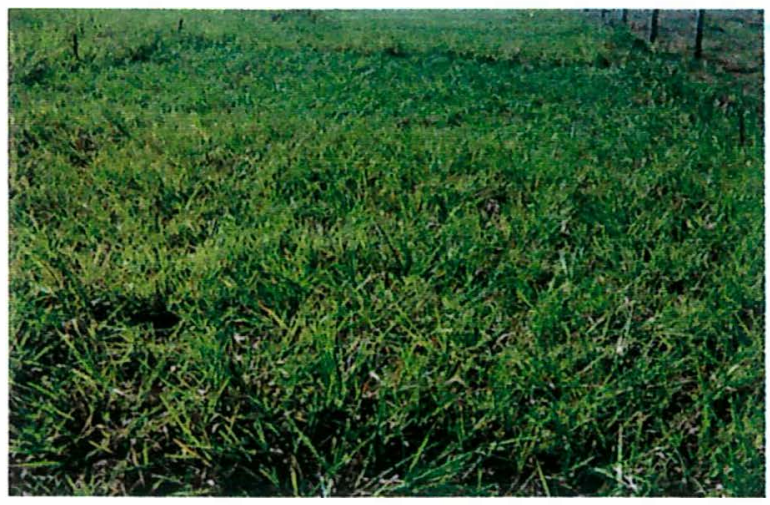

(b)

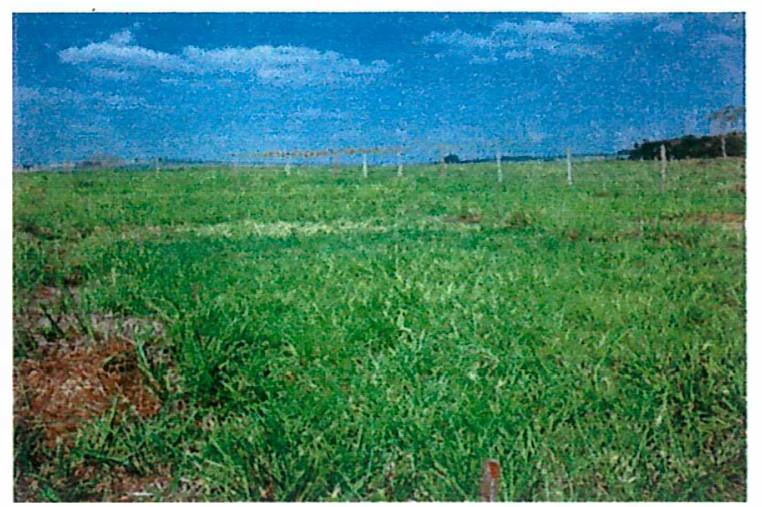

(d)

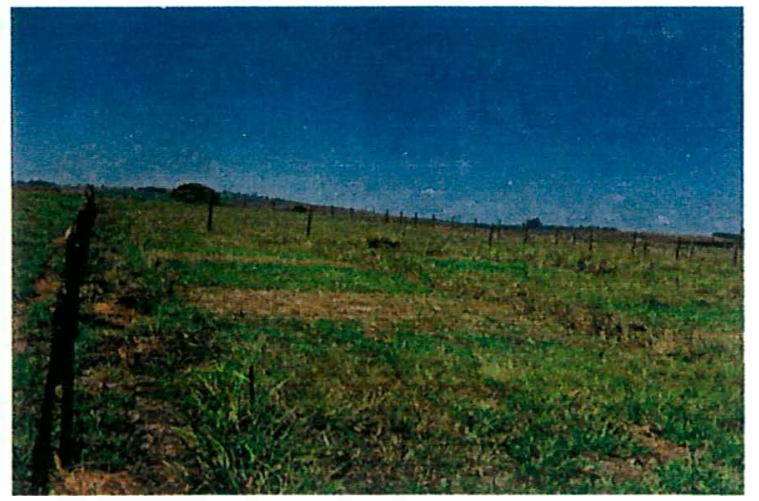

Figura 13 Períodos de uso para o Panicum maximum cv. Mombaça, onde a pastagem foi amostrada em: (a) junho; (b) julho; (c) agosto e (d) setembro.

(a) Motosegadeira utilizada para o corte da área experimental. 
Wilson et al. (1975), verificaram influência do estresse hídrico em parâmetros associados com a qualidade da forragem de Panicum maximum var. trichoglume, onde verificaram menor porcentagem de digestibilidade "in vitro" da matéria seca para lâminas verdes sob plantas em estresse hidrico quando comparadas às lâminas verdes de plantas controle. De maneira diferente, os caules e lâminas mortas de plantas sob estresse tiveram maior digestibilidade do que os das plantas controle; assim como os conteúdos de parede celular nos vários tecidos das plantas estressadas foram menores que das controle. Esses efeitos foram explicados pelo fato do estresse hídrico atrasar a elongação e florescimento dos caules. Wilson (1983), em experimento similar, com gramineas e leguminosas tropicais sob condições de clima semi-árido, relatou que geralmente a digestibilidade "in vitro" da matéria seca de gramineas estressadas hidricamente são similares ou mais elevadas do que para plantas não estressadas, ressaltando o vagaroso desenvolvimento dos colmos nas gramineas sob estresse hídrico. Conteúdos de parede celular e lignina em plantas estressadas foram similares ou menores do que plantas controle. Em contraste, as folhas de Siratro sob condições de estresse apresentaram menores digestibilidades do que folhas de plantas controle que haviam sido expandidas recentemente, bem como apresentaram altos conteúdos em lignina e celulose e menores em hemicelulose.

Segundo Norton (1982), as espécies dos gêneros Panicum, Chloris e Hyparthenia são caracterizadas por apresentarem relativamente altas taxas de declínio na digestibilidade com o avanço da idade, quando comparadas aos gêneros Brachiaria, Setária e Digitária, sendo tal declínio não observado neste trabalho, uma vez que os coeficientes de DIVMS aumentaram com o passar do tempo (Tabela 13).

Pelas Tabelas 14 e 15 e Figura 12, constatou-se que os teores de lignina e hemicelulose, sofreram influência dos periodos de uso, em relação às diferentes vedações. Para a variável hemicelulose, os menores teores foram encontrados em

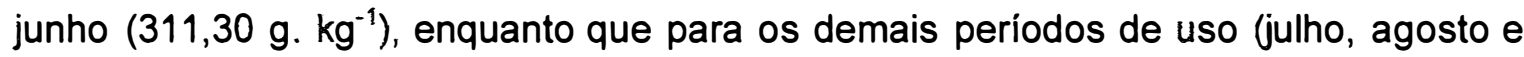
setembro) não ocorreram diferenças significativas. De acordo com Eastridge (1997), a hemicelulose é a fração da fibra mais rapidamente digerida no rúmen. A variável lignina apresentou distribuição observada na Figura 12 ao longo dos meses de uso da pastagem, com maiores teores registrados em junho, e menores em agosto e setembro, apresentando também diferenças significativas entre as épocas de vedação, com valores mais altos para a vedação realizada em 10/03, não diferindo 
estatisticamente da realizada em 07/04. Os teores elevados de lignina, que apresentam-se como fração indigestivel da fibra, encontrados no mês de junho, em contraste aos menores teores de hemicelulose (Figura 12), ocasionaram redução na DIVMS desse periodo de uso (Figura 12). Estes resultados podem ser explicados provavelmente devido à menor disponibilidade de luz (menor fotoperíodo) e temperaturas elevadas apresentadas em junho, concorrendo para maiores proporções de lignina, bem como do padrão de crescimento das forrageiras tropicais, as quais apresentam o crescimento sigmoidal, com mais rebrotas para os períodos de uso ao final da estiagem, caracterizando um capim de melhor qualidade, enquanto que o amostrado em junho, apresentava-se mais velho, portanto mais fibroso e menos digestivel, como já discutido anteriormente.

Tabela 14. Teores de lignina $\left(\mathrm{g} \mathrm{kg}^{-1}\right)$ da parte aérea do Panicum maximum cv. Mombaça em relação às épocas de vedação e periodos de uso (média de quatro repetições).

\begin{tabular}{|c|c|c|c|c|c|}
\hline \multirow{2}{*}{$\begin{array}{l}\text { Epocas de } \\
\text { Vedação(1) }^{(1)}\end{array}$} & \multicolumn{4}{|c|}{ Períodos de Uso(2) } & \multirow[b]{2}{*}{ Média } \\
\hline & Junho & Julho & Agosto & Setembro & \\
\hline 10/03/1997 & 28,55 & 21,10 & 17,20 & 16,93 & $20,95 a$ \\
\hline 24/03/1997 & 22,20 & 15,88 & 14,00 & 14,73 & $16,70 \mathrm{~b}$ \\
\hline 07/04/1997 & 23,13 & 17,68 & 15,50 & 15,10 & $17,85 a b$ \\
\hline Média & $24,63 \mathrm{~A}$ & 18,22 & $15,56 \mathrm{~B}$ & $15,58 \mathrm{~B}$ & \\
\hline
\end{tabular}

Médias seguidas da mesma letra não diferem significativamente entre si $(P>0,05)$ pelo teste de Tukey. ns $=$ não significativo $(P>0,05)$ pelo teste de Tukey.

C.V. $(\%)^{(1)}=20,16$

C.V. $(\%)^{(2)}=20,52$ 
Tabela 15. Teores de hemicelulose $\left(\mathrm{g} \mathrm{kg}^{-1}\right)$ da parte aérea do Panicum maximum cv. Mombaça em relação às épocas de vedação e períodos de uso (média de quatro repetições).

\begin{tabular}{llllll}
\hline Épocas de & \multicolumn{5}{c}{ Períodos de Uso } \\
\cline { 2 - 6 } Vedação & Junho & Julho & Agosto & Setembro & Média \\
\hline $10 / 03 / 1997$ & 309,38 & 329,13 & 331,98 & 332,68 & $325,79 \mathrm{~ns}$ \\
$24 / 03 / 1997$ & 313,63 & 323,80 & 327,50 & 330,15 & $323,77 \mathrm{~ns}$ \\
$07 / 04 / 1997$ & 310,90 & 313,30 & 324,35 & 331,33 & $319,97 \mathrm{~ns}$ \\
\hline Média & $311,30 \mathrm{~B}$ & $322,08 \mathrm{~A}$ & $327,94 \mathrm{~A}$ & $331,38 \mathrm{~A}$ & \\
\hline
\end{tabular}

Médias seguidas da mesma letra não diferem significativamente entre si $(P>0,05)$ pelo teste de Tukey. ns $=$ não significativo $(P>0,05)$ pelo teste de Tukey. C.V. $(\%)=2,57$

Os teores de FDN e FDA, encontram-se nas Tabelas 16 e 17 e Figura 14, onde verificou-se somente efeito das épocas de vedação, com teores máximos obtidos em 10/03, para ambas as variáveis, devido ao maior período de tempo que as forrageiras tiveram de crescimento, acumulando material fibroso com o avanço da idade da planta e condições climáticas favoráveis ao crescimento.

Tabela 16. Teores de fibra em detergente neutro - FDN $\left(\mathrm{g} \mathrm{kg}^{-1}\right)$ da parte aérea do Panicum maximum cv. Mombaça em relação às épocas de vedação e períodos de uso (média de quatro repetições).

\begin{tabular}{llllll}
\hline $\begin{array}{l}\text { Epocas de } \\
\text { Vedação }\end{array}$ & \multicolumn{5}{c}{ Periodos de Uso } \\
\cline { 2 - 6 } & Junho & Julho & Agosto & Setembro & Média \\
\hline 10/03/1997 & 654,65 & 665,48 & 673,48 & 667,93 & $665,38 \mathrm{a}$ \\
$24 / 03 / 1997$ & 634,58 & 635,50 & 634,70 & 645,53 & $637,58 \mathrm{~b}$ \\
$07 / 04 / 1997$ & 634,85 & 637,88 & 639,65 & 646,50 & $639,72 \mathrm{~b}$ \\
& & & & \\
\hline Média & $641,36 \mathrm{~ns}$ & $646,28 \mathrm{~ns}$ & $649,28 \mathrm{~ns}$ & $653,32 \mathrm{~ns}$ \\
\hline
\end{tabular}

Médias seguidas da mesma letra não diferem significativamente entre si $(P>0,05)$ pelo teste de Tukey. ns $=$ não significativo $(P>0,05)$ pelo teste de Tukey.

C.V. $(\%)=1,41$ 
(a)

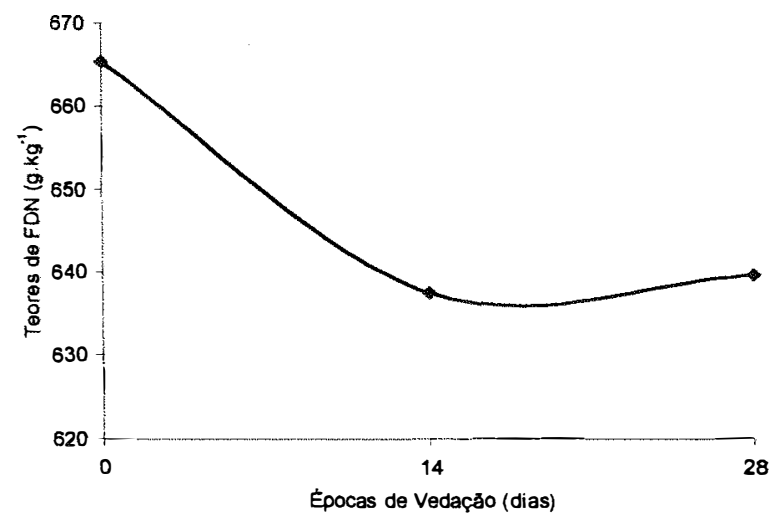

(c)

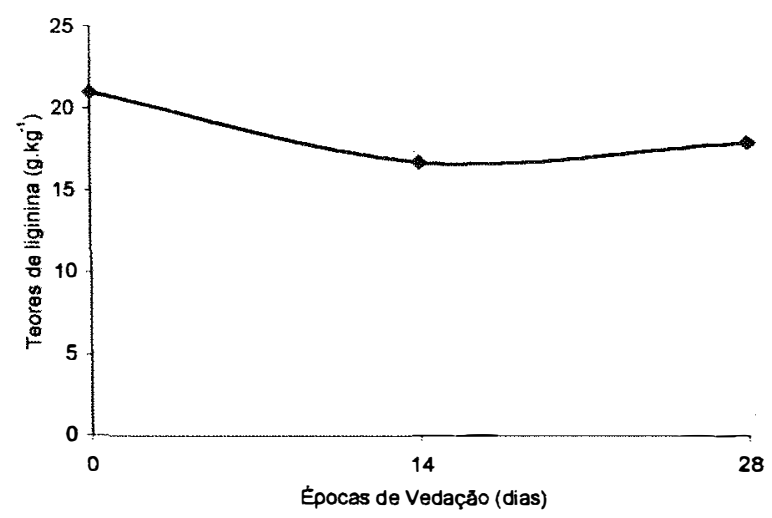

(b)

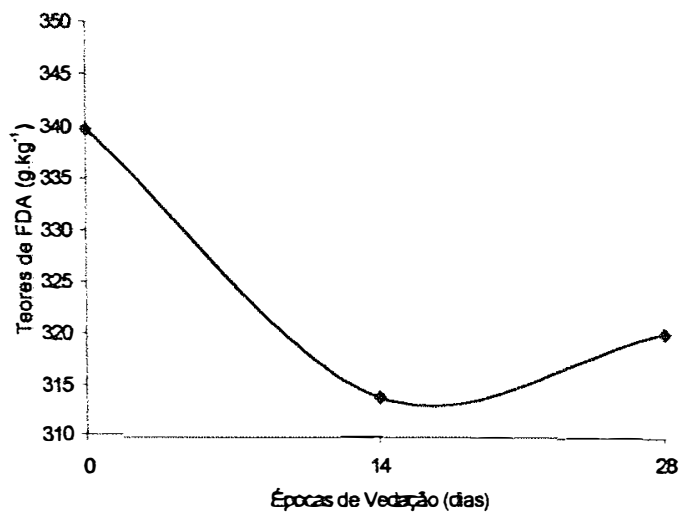

Figura 14. Teores de FDN (a), FDA (b) e lignina (c) $\left(g \cdot \mathrm{kg}^{-1}\right)$, obtidos da parte aérea do Panicum maximum cv. Mombaça, em função das épocas de vedação onde 0 corresponde a vedação realizada em 10/03/97, 14 corresponde a vedação realizada em 24/03/97 e 28 corresponde a vedação realizada em 07/04/97. 
Tabela 17. Teores de fibra em detergente ácido - FDA $\left(\mathrm{g} \mathrm{kg}^{-1}\right)$ da parte aérea do Panicum maximum cv. Mombaça em relação às épocas de vedação e periodos de uso (média de quatro repetições).

\begin{tabular}{llllll}
\hline Épocas de & \multicolumn{5}{c}{ Periodos de Uso } \\
\cline { 2 - 6 } Vedação & Junho & Julho & Agosto & Setembro & Média \\
\cline { 2 - 6 } 10/03/1997 & 345,25 & 336,43 & 341,53 & 335,25 & $339,61 \mathrm{a}$ \\
$24 / 03 / 1997$ & 320,93 & 311,70 & 307,18 & 315,35 & $313,79 \mathrm{~b}$ \\
$07 / 04 / 1997$ & 323,95 & 324,60 & 315,33 & 315,18 & $319,76 \mathrm{~b}$ \\
& & & & & \\
\hline Média & $330,04 \mathrm{~ns}$ & $324,24 \mathrm{~ns}$ & $321,34 \mathrm{~ns}$ & $321,93 \mathrm{~ns}$ &
\end{tabular}

Médias seguidas da mesma letra não diferem significativamente entre si $(P>0,05)$ pelo teste de Tukey. ns $=$ não significativo $(P>0,05)$ pelo teste de Tukey.

C.V. $(\%)=1,58$

Wilson et al. (1976), inferiram que efeitos de elevadas temperaturas sobre Panicum maximum var. trichoglume, Cenchrus ciliaris, Setaria sphacelata, Paspalum dilatatum e Pennisetum clandestinum foram marcantes, reduzindo a digestibilidade da matéria seca e aumentando o conteúdo de parede celular em folhas que haviam sido expandidas recentemente e que plantas sobre estresse hidrico apresentaram menores digestibilidades e maiores conteúdos de parede celular, ressaltando que efeitos da umidade atmosférica são pequenos e inconsistentes em plantas sem estresse hídrico.

Burton et al. (1959), relataram influência da intensidade luminosa sobre o crescimento de $C$. dactylon, verificando aumentos progressivos de lignina de 9,2\% para $10,4 \%$, quando a disponibilidade de luz diminuiu de $100 \%$ para $30 \%$. Os resultados encontrados por Costa et al. (1993) e Wan Hassan (1990), discordam dos encontrados para o Panicum maximum cv. Mombaça, relatando espessamento da parede celular com maiores depósitos de lignina, com a maturidade da planta. 


\section{3 Composição mineral}

\section{4 .3 .1 Brachiaria brizantha cv. Marandu}

O Quadro 1 e as Figuras 15 e 16 apresentam os teores de N, P, Ca e S avaliados na MS da Brachiaria brizantha cv. Marandu, em função das épocas de vedação e periodos de uso. Para o $\mathrm{P}, \mathrm{Ca}$ e $\mathrm{S}$, verificou-se diferenças significativas para os periodos de uso, não apresentando variações significativas entre as épocas de vedação estudadas; enquanto que para o nutriente $\mathrm{N}$ foram verificadas variações também em relação às épocas de vedação.

Os teores de $\mathrm{N}$ (Figura 15), variaram em função das vedações com maiores teores na época de vedação mais tardia. Os periodos de uso apresentaram teores de aproximadamente 6 a $10 \mathrm{~g} \cdot \mathrm{kg}^{-1}$ com menores valores para as utilizações de agosto, considerados inferiores em todos os períodos aos teores médios normalmente encontrados em forrageiras tropicais por Malavolta et al. (1986) (17 g kg $\mathrm{gg}^{-1}$, não apresentando reduções nos teores com o aumento da maturidade da planta, como relatam Gomide (1978) e Little (1982). Segundo Hogdson (1990), valores inferiores a $10 \mathrm{~g} . \mathrm{kg}^{-1}$ de $\mathrm{N}$ limitam ingestão de forragem pelos ruminantes. 
Quadro 1. Variáveis obtidas em função das épocas de vedação e períodos de uso da parte aérea da Brachiaria brizantha cv. Marandu (média de quatro repetições).

\begin{tabular}{|l|lll|llll|}
\hline \multirow{2}{*}{ VARI ÁVEL } & \multicolumn{3}{|c|}{ EPPCAS DE VEDAÇẢO } & \multicolumn{4}{|c|}{ PERIOOS DE USO } \\
\hline $\mathrm{N}\left(\mathrm{g} \cdot \mathrm{kg}^{-1}\right)^{(1)}$ & $10 / 03 / 97$ & $24 / 03 / 97$ & $07 / 04 / 9$ & Junho & Julho & Agosto & Setembro \\
\hline $\mathrm{P}\left(\mathrm{g} \cdot \mathrm{kg}^{-1}\right)^{(2)}$ & $1,86 \mathrm{a}$ & $8,26 \mathrm{~b}$ & $8,34 \mathrm{c}$ & 9,13 & $8,51 \mathrm{~A}$ & $6,53 \mathrm{~B}$ & $8,45 \mathrm{~A}$ \\
\hline $\mathrm{Ca}\left(\mathrm{g} \cdot \mathrm{kg}^{-1}\right)^{(3)}$ & $6,10 \mathrm{~ns}$ & $5,70 \mathrm{~ns}$ & $5,90 \mathrm{~ns}$ & $5,04 \mathrm{C}$ & $5,57 \mathrm{BC}$ & $6,73 \mathrm{~A}$ & $6,27 \mathrm{AB}$ \\
\hline $\mathrm{S}\left(\mathrm{g} \cdot \mathrm{kg}^{-1}\right)^{(4)}$ & $1,66 \mathrm{~ns}$ & $1,70 \mathrm{~ns}$ & $1,76 \mathrm{~ns}$ & $1,57 \mathrm{~B}$ & $1,89 \mathrm{~A}$ & $1,88 \mathrm{~A}$ & $1,49 \mathrm{~B}$ \\
\hline $\mathrm{N}$ extr. $\left(\mathrm{g} \cdot \mathrm{m}^{-2}\right)^{(5)}$ & $0,63 \mathrm{a}$ & $0,30 \mathrm{~b}$ & $0,30 \mathrm{~b}$ & $0,45 \mathrm{~ns}$ & $0,41 \mathrm{~ns}$ & $0,36 \mathrm{~ns}$ & $0,42 \mathrm{~ns}$ \\
\hline $\mathrm{P}$ extr. $\left(\mathrm{g} \cdot \mathrm{m}^{-2}\right)^{(6)}$ & $0,12 \mathrm{a}$ & $0,05 \mathrm{~b}$ & $0,05 \mathrm{~b}$ & $0,08 \mathrm{~ns}$ & $0,07 \mathrm{~ns}$ & $0,08 \mathrm{~ns}$ & $0,06 \mathrm{~ns}$ \\
\hline Ca extr$\left(\mathrm{g} \cdot \mathrm{m}^{-2}\right)^{(7)}$ & $0,49 \mathrm{a}$ & $0,22 \mathrm{~b}$ & $0,21 \mathrm{~b}$ & $0,27 \mathrm{~ns}$ & $0,27 \mathrm{~ns}$ & $0,37 \mathrm{~ns}$ & $0,32 \mathrm{~ns}$ \\
\hline $\mathrm{S} \mathrm{extr}\left(\mathrm{g} \cdot \mathrm{m}^{-2}\right)^{(8)}$ & $0,13 \mathrm{a}$ & $0,06 \mathrm{~b}$ & $0,06 \mathrm{~b}$ & $0,08 \mathrm{~ns}$ & $0,09 \mathrm{~ns}$ & $0,10 \mathrm{~ns}$ & $0,08 \mathrm{~ns}$ \\
\hline $\mathrm{N} / \mathrm{S}\left(\mathrm{g} \cdot \mathrm{kg}^{-1}\right)^{(9)}$ & $4,76 \mathrm{~ns}$ & $5,00 \mathrm{~ns}$ & $4,92 \mathrm{~ns}$ & $5,81 \mathrm{~A}$ & $4,55 \mathrm{~B}$ & $3,49 \mathrm{C}$ & $5,72 \mathrm{~A}$ \\
\hline Ca/P $\left(\mathrm{g} \cdot \mathrm{kg}^{-1}\right)^{(10)}$ & $4,15 \mathrm{~ns}$ & $4,36 \mathrm{~ns}$ & $4,55 \mathrm{~ns}$ & $3,59 \mathrm{C}$ & $3,59 \mathrm{C}$ & $4,72 \mathrm{~B}$ & $5,51 \mathrm{~A}$ \\
\hline
\end{tabular}

Médias seguidas da mesma letra (minúscula para épocas de vedação e maiúscula para períodos de uso), não diferem significativamente entre si $(P>0,05)$ pelo teste de Tukey.

Obs: ns =não significativo pelo teste de Tukey, ao nivel de $5 \%$ de significância. $(P>0,05)$.

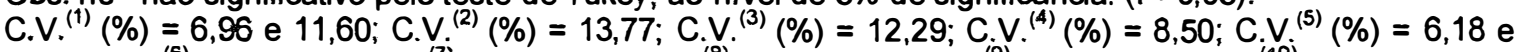
30,$90 ;$ C.V. ${ }^{(6)}(\%)=35,83 ; C . V .{ }^{(7)}(\%)=31,92 ; C . V .{ }^{(8)}(\%)=25,22 ; C . V .{ }^{(9)}(\%)=15,98 ; C . V .{ }^{(10)}=12,67$. 
(a)

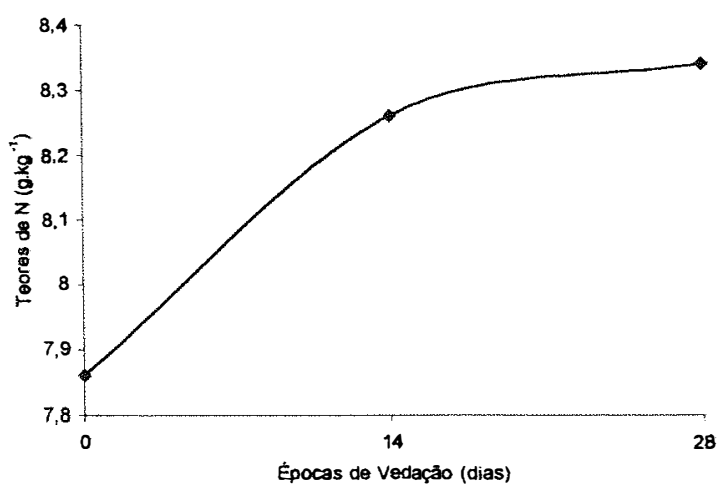

(b)

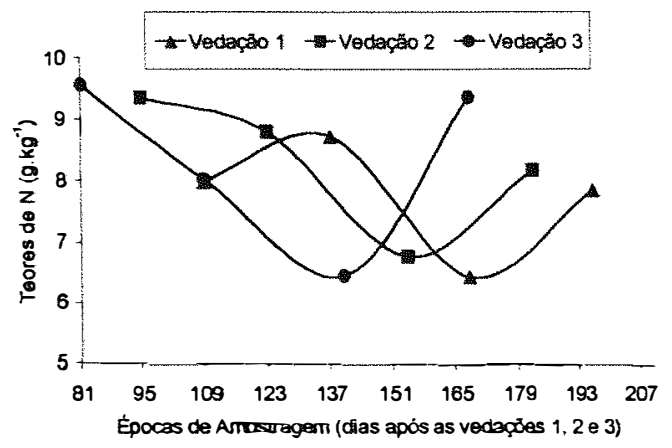

Figura 15. Teores de $\mathrm{N}\left(\mathrm{g} \cdot \mathrm{kg}^{-1}\right)$ obtidos da parte aérea da Brachiaria brizantha cv. Marandu, para as épocas de vedação, onde 0, 14 e 28 correspondem as vedações realizadas em 10/03/97, 24/03/97 e 07/04/97, respectivamente (a); em função dos períodos de uso avaliados - épocas de amostragem (junho, julho, agosto e setembro), em dias após as vedações 1 (10/03/97), $2(24 / 03 / 97)$ e $3(07 / 04 / 97)(b)$.

Para Corsi (1994), o aumento no fornecimento de $\mathrm{N}$ melhora o valor nutritivo da forragem, reduzindo o teor de carboidratos solúveis, aumentando o teor protéico e diminuindo o teor de fibra. Para Monteiro (1995), na ausência de limites edafoclimáticos, o suprimento de $\mathrm{N}$ apresenta-se como o fator de maior impacto na produtividade da planta forrageira bem estabelecida.

Em relação aos teores de $P$ obtidos, em todas as idades de corte (Figura 16), com a distribuição apresentada, foram inferiores ao teor de $2,1 \mathrm{~g} . \mathrm{kg}^{-1}$, considerado médio por Malavolta et ał. (1986), com maiores valores para as utilizações intermediárias (Quadro 1). Segundo Gomide (1978) e Minson (1990), ocorre redução nos teores de P com o avanço da idade da planta. De acordo com Robinson (1996) a faixa crítica para os teores de $P$ estaria entre $1,92 \mathrm{~g} \cdot \mathrm{kg}^{-1}$ a $2,8 \mathrm{~g} \cdot \mathrm{kg}^{-1}$, valores superiores aos observados para a $B$. brizantha que variou de $1,14 \mathrm{~g} \cdot \mathrm{kg}^{-1}$ a $1,58 \mathrm{~g} \cdot \mathrm{kg}^{-1}$. 
(a)

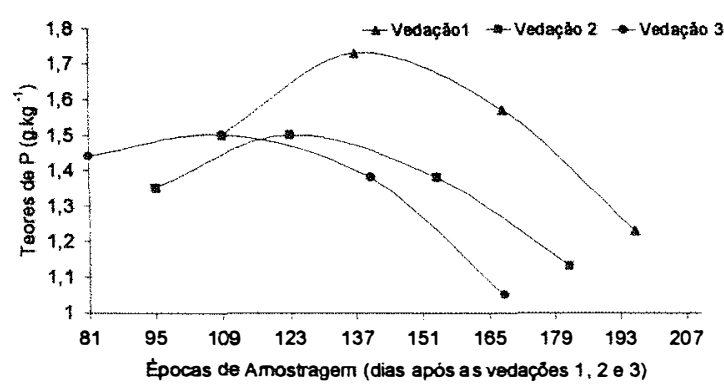

(c) (b)

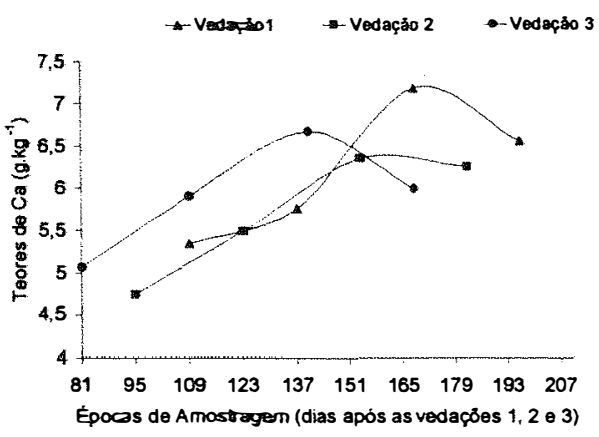

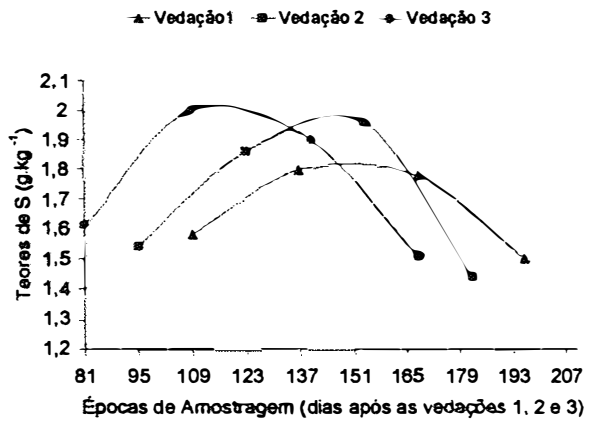

Figura 16. Teores de $\mathrm{P}(\mathrm{a})$, Ca (b) e S (c) $\left(\mathrm{g} \cdot \mathrm{kg}^{-1}\right)$ obtidos da parte aérea da Brachiaria brizantha cv. Marandu, em função dos periodos de uso avaliados - épocas de amostragem (junho, julho, agosto e setembro), em dias após as vedações 1 (10/03/97), 2 (24/03/97) e 3 (07/04/97).

Os teores de Ca observados para os periodos de uso da pastagem nas secas, de acordo com a Quadro 1 (5,04 g. $\mathrm{kg}^{-1}$ a 6,73 g. $\left.\mathrm{kg}^{-1}\right)$ e Figura 16, foram superiores aos teores médios encontrados em forrageiras tropicais por Malavolta et al. (1986), $(4,6$ g. $\left.\mathrm{kg}^{-1}\right)$. Os periodos de junho $\left(5,04 \mathrm{~g} \cdot \mathrm{kg}^{-1}\right)$ e julho $\left(5,57 \mathrm{~g} \cdot \mathrm{kg}^{-1}\right)$, foram mais próximos aos teores médios para as forrageiras tropicais, sem variações significativas. Para os teores médios de $S$ observados (Figura 16), os valores situaram-se acima dos encontrados por Malavolta et al. (1986) (1 g. $\left.\mathrm{kg}^{-1}\right)$ para gramíneas no Estado de São Paulo. De acordo com Gallo et al. (1974) esses valores encontrados (1,49 g. $\mathrm{kg}^{-1}$ a 1,89 g. $\left.\mathrm{kg}^{-1}\right)$ situam-se na concentração adequada de $S$ para plantas $\left(1,0 \mathrm{~g} \cdot \mathrm{kg}^{-1}\right.$ a $\left.3,0 \mathrm{~g} \cdot \mathrm{kg}^{-1}\right)$. Para todos os nutrientes avaliados não foram verificadas reduções com o avanço da idade da planta. 
De maneira discordante, Malavolta et al.(1986), verificaram diminuições com a maturidade, podendo ocorrer devido à redistribuição destes dentro da planta. De maneira semelhante, as relações entre os nutrientes N/S e Ca/P (Quadro 1 e Figura 17) também apresentaram diferenças significativas somente para os periodos de uso. Para a relação N/S os periodos de uso face às épocas de vedação apresentaram a distribuição observada na Figura 17, com maiores valores para os meses de junho e setembro (acima de 5/1), ficando entretanto, muito aquém dos sugeridos por Church (1993), cuja relação ideal preconizada foi de $15 / 1$ para bovinos, e dos encontrados em Vitti e Novaes (1986), (14/1) para plantas no estágio de maturidade. Dessa forma a relação N/S obtida em qualquer época de vedação e periodo avaliado, não atenderia às necessidades da planta e animais.

(a)

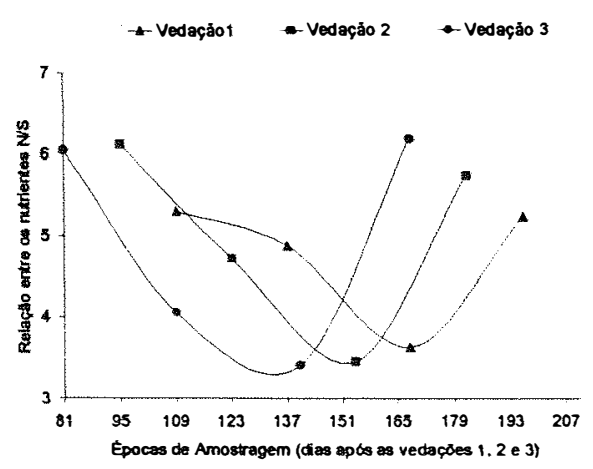

(b)

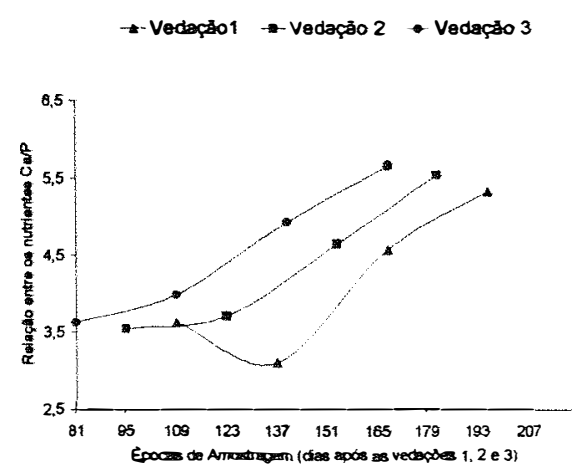

Figura 17 . Relação entre os nutrientes N/S (a) e Ca/P (b) obtidos da parte aérea da Brachiaria brizantha cv. Marandu, em função dos periodos de uso avaliados - épocas de amostragem (junho, julho, agosto e setembro), em dias após as vedações 1 (10/03/97), 2 (24/03/97) e 3 (07/04/97).

De maneira geral, os nutrientes observados em B. brizantha não diminuiram com o avanço da idade da planta como verificado por Malavolta et al. (1986) devido provavelmente ao desbalanço observado na nutrição mineral das plantas de Brachiaria brizantha cv. Marandu, ocasionado possivelmente pelas práticas deficientes de adubação. 
A baixa relação N/S observada deve-se, em parte, aos teores de $\mathrm{N}$ abaixo das médias encontradas em Malavolta et al. (1986). Ressaltando ainda, segundo Werner (1984), que o $\mathrm{N}$ de modo geral pode ser considerado como o principal nutriente das gramíneas forrageiras, proporcionando aumento imediato na produção de forragem, o que provavelmente ocasionou reduções na produção da Brachiaria brizantha cv. Marandu, uma vez que constatou-se a deficiência e o desequilíbrio desse nutriente, devido principalmente ao manejo da pastagem, com intervalos de aproximadamente três anos entre adubações.

A relação Ca/P observada em todas as amostragens (Quadro 1 e Figura 17), (3,6/1 a 5,5/1) foi superior a 1/1, valor mínimo apresentado por Wise et al. (1963), cujas observações relataram conseqüências prejudiciais ao crescimento e a eficiência alimentar de bezerros ingerindo alimentos com relação $\mathrm{Ca} / \mathrm{P}$, inferior a $1 / 1$. Este desbalanço entre os nutrientes Ca/P verificados na Brachiaria brizantha cv. Marandu, deve-se principalmente à elevada concentração de $\mathrm{Ca}$ observada em todas as utilizações, (provavelmente promovida pela calagem) e também à níveis de $P$ inferiores aos médios encontrados em Malavolta et al. (1986).

Wan Hassan et al. (1990), registraram concentrações médias anuais (três anos) dos nutrientes P e Ca para Brachiaria brizantha cv. Marandu: $1,5 \mathrm{~g} \cdot \mathrm{kg}^{-1}$ para o primeiro ano experimental e aproximadamente $1,9 \mathrm{~g} \cdot \mathrm{kg}^{-1}$, para os anos subsequentes, relatando reduções médias em torno de $0,7 \mathrm{~g} \cdot \mathrm{kg}^{-1}$ para o nutriente $P$ e $0,2 \mathrm{~g} \cdot \mathrm{kg}^{-1}$ para $\mathrm{Ca}$, para 0 segundo e terceiro anos, quando a idade entre cortes aumentou de duas para oito semanas.

Os dados do Quadro 1 e da Figura 18, quantificam a extração dos nutrientes $\mathbf{N}$, $P, C a$ e $S$ da matéria seca, onde verificou-se que a extração máxima dos nutrientes estudados coincidiu com a máxima produção em MS, obtida em 10/03, concordando com o encontrado por Robinson (1996), que relatou que a extração máxima dos nutrientes na matéria seca, ocorre devido à produção da mesma. 


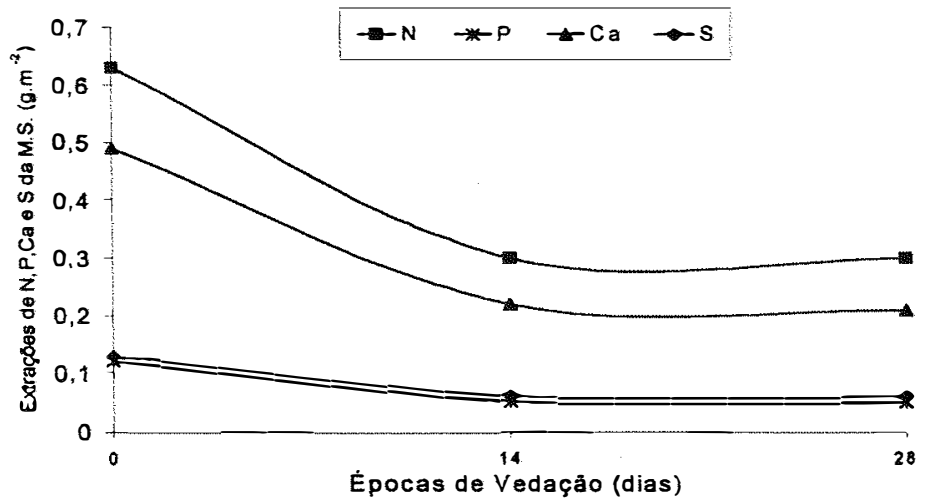

Figura 18. Extrações de $\mathrm{N}, \mathrm{P}, \mathrm{Ca}$ e $\mathrm{S}$ da matéria seca $\left(\mathrm{g} \cdot \mathrm{m}^{-2}\right)$ da parte aérea da Brachiaria brizantha cv. Marandu, em função dos períodos de uso avaliados - épocas de amostragem (junho, julho, agosto e setembro), em dias após as vedações 1 (10/03/97), 2 (24/03/97) e 3 (07/04/97).

\section{3. 2 Panicum maximum cv. Mombaça}

O Quadro 2, apresenta os teores de N, P, Ca e S avaliados na MS do Panicum maximum cv. Mombaça, em função das épocas de vedação e períodos de uso. Para o teor de N, (Figura 19) foi verificado efeito significativo entre as épocas de vedação, apresentando menores valores $\left(9,59 \mathrm{~g} \cdot \mathrm{kg}^{-1}\right)$, para a vedação em 10/03 e valores superiores para as demais vedações, sem diferenças significativas entre as mesmas. Para as utilizações, observou-se maiores valores em junho, acima de $11,00 \mathrm{~g} \cdot \mathrm{kg}^{-1} \mathrm{e}$ agosto menores valores, (inferiores a $8,00 \mathrm{~g} \cdot \mathrm{kg}^{-1}$ ), teores inferiores à concentração do mineral, em média para forrageiras tropicais $\left(17 \mathrm{~g}_{\mathrm{kg}}{ }^{-1}\right)$, de acordo com Malavolta et al. (1986). Corsi (1994), relatou que a adubação nitrogenada reduz a velocidade de queda do valor nutritivo das forrageiras ao longo do período de tempo, mantendo maiores proporções folha/haste e nutrientes digestiveis na matéria seca, inferindo ainda, que carências de $\mathrm{N}$ promovem secamento e queda precoce de folhas, o que provavelmente contribuiu para os acúmulos de material morto, ao longo do ciclo da gramínea. 
Quadro 2. Variáveis obtidas em função das épocas de vedação e períodos de uso da parte aérea do Panicum maximum cv. Mombaça (média de quatro repetições).

\begin{tabular}{|c|c|c|c|c|c|c|c|}
\hline \multirow[b]{2}{*}{ VARIÁVEL } & \multicolumn{3}{|c|}{ EPOCAS DE VEDAÇĀO } & \multicolumn{4}{|c|}{ PERIODOS DE USO } \\
\hline & 10/03/9 & $24 / 03 / 97$ & $07 / 04 / 97$ & Junho & Julho & Agosto & Setembro \\
\hline $\mathrm{N}\left(\mathrm{g} \cdot \mathrm{kg}^{-1}\right)^{(1)}$ & $9,59 b$ & $10,48 a$ & $10,78 \mathrm{a}$ & $12,42 \mathrm{~A}$ & $10,44 \mathrm{~B}$ & $8,79 \mathrm{C}$ & $9,49 B C$ \\
\hline$P\left(g \cdot \mathrm{kg}^{-1}\right)^{(2)}$ & $1,79 \mathrm{~ns}$ & $1,69 \mathrm{~ns}$ & $1,70 \mathrm{~ns}$ & $1,71 \mathrm{~ns}$ & $1,96 \mathrm{~ns}$ & $1,67 \mathrm{~ns}$ & $1,56 \mathrm{~ns}$ \\
\hline $\mathrm{Ca}\left(\mathrm{g} \cdot \mathrm{kg}^{-1}\right)^{(3)}$ & $6,74 \mathrm{~ns}$ & $7,32 \mathrm{~ns}$ & $7,03 \mathrm{~ns}$ & $5,74 \mathrm{~B}$ & $7,30 \mathrm{~A}$ & $7,20 \mathrm{~A}$ & $7,87 \mathrm{~A}$ \\
\hline$S\left(g \cdot \mathrm{kg}^{-1}\right)^{(4)}$ & $0,99 \mathrm{~ns}$ & $1,04 \mathrm{~ns}$ & $0,95 \mathrm{~ns}$ & $1,17 \mathrm{~A}$ & $1,00 \mathrm{AB}$ & $0,97 \mathrm{AB}$ & $0,83 \mathrm{~B}$ \\
\hline P extr. $\left(g \cdot \mathrm{m}^{-2}\right)^{(5)}$ & $0,30 a$ & $0,16 \mathrm{~b}$ & $0,15 \mathrm{~b}$ & $0,15 \mathrm{~B}$ & $0,21 \mathrm{AB}$ & $0,23 \mathrm{~A}$ & $0,23 \mathrm{~A}$ \\
\hline Ca extr $\left(9 \cdot \mathrm{m}^{-2}\right)^{(6)}$ & $1,14 a$ & $0,73 b$ & $0,66 \mathrm{~b}$ & $0,52 \mathrm{C}$ & $0,75 \mathrm{BC}$ & $0,94 \mathrm{AB}$ & $1,18 \mathrm{~A}$ \\
\hline S extr $\left(g \cdot m^{-2}\right)^{(7)}$ & $0,17 a$ & $0,10 \mathrm{~b}$ & $0,08 \mathrm{~b}$ & $0,10 \mathrm{~ns}$ & $0,10 \mathrm{~ns}$ & $0,13 \mathrm{~ns}$ & $0,12 \mathrm{~ns}$ \\
\hline N/S $\left(g . \mathrm{kg}^{-1}\right)^{(8)}$ & $10,49 \mathrm{~ns}$ & $10,59 \mathrm{~ns}$ & $13,93 \mathrm{~ns}$ & $12,67 \mathrm{~ns}$ & $10,48 \mathrm{~ns}$ & $9,33 \mathrm{~ns}$ & $14,19 \mathrm{~ns}$ \\
\hline $\mathrm{Ca} / \mathrm{P}\left(\mathrm{g} \cdot \mathrm{kg}^{-1}\right)^{(9)}$ & $3,83 \mathrm{~ns}$ & $4,46 \mathrm{~ns}$ & $4,47 \mathrm{~ns}$ & $3,41 \mathrm{~B}$ & $3,77 \mathrm{~B}$ & $4,43 \mathrm{AB}$ & $5,40 \mathrm{~A}$ \\
\hline
\end{tabular}

Médias seguidas da mesma letra (minúscula para épocas de vedação e maiúscula para períodos de uso), não diferem significativamente entre si $(P>0,05)$ pelo teste de Tukey.

Obs: ns =nåo significativo pelo teste de Tukey, ao nivel de $5 \%$ de significância. $(P>0,05)$.

C.V. ${ }^{(1)}(\%)=11,50$ e 10,$08 ; C . V .{ }^{(2)}(\%)=n s$ C.V. ${ }^{(3)}(\%)=19,46 ; C . V .{ }^{(4)}(\%)=41,85 ;$ C.V. ${ }^{(5)}(\%)=35,96$ e 32,$22 ; C . V .{ }^{(6)}(\%)=28,67$ e 30,$30 ; C . V .{ }^{(7)}(\%)=21,19 ; C . V .{ }^{(8)}(\%)=n s ; C . V .{ }^{(9)}(\%)=19,58$. 
(a)

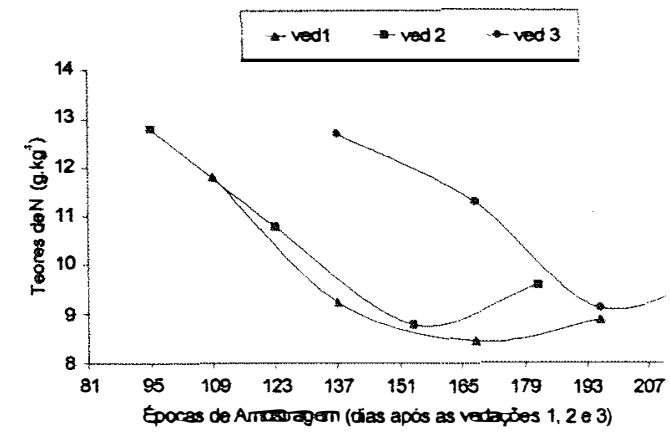

(c)

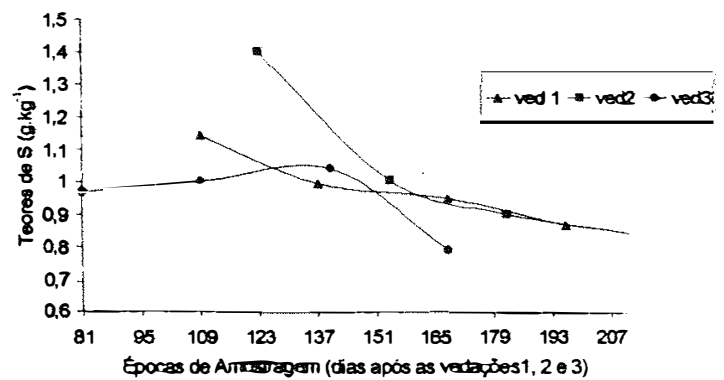

(b)

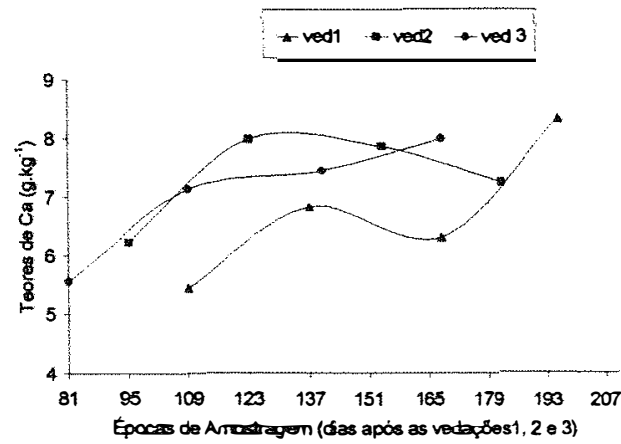

(d)

Figura 19 . Teores de $\mathrm{N}(\mathrm{a})$, Ca (b) e $S$ (c) $\left(\mathrm{g} \cdot \mathrm{kg}^{-1}\right)$ obtidos da parte aérea do Panicum maximum cv. Mombaça, em função dos períodos de uso avaliados épocas de amostragem (junho, julho, agosto e setembro), em dias após as vedações 1 (10/03/97), 2 (24/03/97) e 3 (07/04/97).

Para o $\mathrm{Ca}$ e o $\mathrm{S}$, os teores diferiram significativamente em função dos periodos de uso, sem apresentar uma tendência definida desses nutrientes face às épocas de vedação avaliadas, como pode ser observado na Figura 19. Para o $\mathrm{Ca}$, as amostragens de julho, agosto e setembro, apresentaram teores maiores, variando aproximadamente de 6,0 a $8,5 \mathrm{~g} \cdot \mathrm{kg}^{-1}$, enquanto que a de junho, teores inferiores, em tomo de 5,5 a $6,0 \mathrm{~g} \cdot \mathrm{kg}^{-1}$, para qualquer vedação adotada, entretanto, verificou-se que mesmo os valores mínimos foram superiores aos encontrados em Malavolta et al. (1986) para forrageiras tropicais, devido provavelmente à calagem. De maneira diferente, os teores de $S$ foram maiores em junho, e similares estatisticamente aos de julho e agosto. 
Os teores de $\mathrm{P}$ não apresentaram diferenças significativas face às épocas de vedações e amostragens empregadas, e mantiveram-se abaixo dos sugeridos por Malavolta et al. (1986).

Wan Hassan et al. (1990), registraram as respectivas concentrações médias anuais dos nutrientes $P$ e Ca para Panicum maximum: $1,7 \mathrm{~g}^{\mathrm{kg}} \mathrm{ge}^{-1} 1,9 \mathrm{~g} \cdot \mathrm{kg}^{-1}$, para 0 primeiro ano; $1,9 \mathrm{~g} \cdot \mathrm{kg}^{-1}$ e 2,3 g. $\mathrm{kg}^{-1}$, para o segundo e $2,0 \mathrm{~g} \cdot \mathrm{kg}^{-1}$ e $2,7 \mathrm{~g} \cdot \mathrm{kg}^{-1}$ para 0 terceiro ano experimental, relatando ainda, reduções em tomo de $0,7 \mathrm{~g} \mathrm{~kg}^{-1}$ para 0 nutriente $P$ e 0,2 g. $\mathrm{kg}^{-1}$ para $\mathrm{Ca}$, somente para o primeiro ano; com aumentos de 0,4 g. $\mathrm{kg}^{-1}$ para esse nutriente, para os anos seguintes, quando a idade entre cortes aumentou de duas para oito semanas. Em trabalho semelhante, Abaunza et al.(1991), descreveram teores de $\mathrm{Ca}\left(6,6 \mathrm{~g} \cdot \mathrm{kg}^{-1}\right)$ e $\mathrm{P}\left(1,6 \mathrm{~g} \cdot \mathrm{kg}^{-1}\right)$ encontrados nas folhas de Panicum maximum.

Em relação às quantidades de $\mathrm{N}$ extraídas na matéria seca do Panicum maximum cv. Mombaça (Figura 20), ocorreu interação entre as vedações e períodos de uso como pode ser verificado na Tabela 18.

Para a vedação em $10 / 03$ os períodos de uso não apresentaram diferenças significativas entre si, apresentando maiores valores de $\mathrm{N}$ extraídos na vedação de $24 / 03$, com a forrageira utilizada em setembro, enquanto que para o pasto vedado em $07 / 04$, as máximas quantidades de $\mathrm{N}$ extraído foram para os periodos de agosto e setembro, sem diferenças estatísticas do uso em julho.

Tabela 18. Extração de $\mathrm{N}\left(\mathrm{g} \mathrm{m}^{-2}\right)$ da parte aérea da matéria seca do Panicum maximum cv. Mombaça, em relação às épocas de vedação e periodos de uso utilizados (média de quatro repetições).

\begin{tabular}{|c|c|c|c|c|c|c|c|}
\hline \multirow{2}{*}{$\begin{array}{l}\text { Épocas de } \\
\text { Vedação(1) }^{(1)}\end{array}$} & \multicolumn{7}{|c|}{ Periodos de Uso ${ }^{(2)}$} \\
\hline & Junho & & Julho & & Agos & & Setembro \\
\hline $10 / 03$ & 1,85 & A a & 1,37 & $\mathrm{~A} a$ & 1,60 & A a & $1,52 \quad \mathrm{~A} \mathrm{a}$ \\
\hline $24 / 03$ & 0,84 & $B b$ & 0,89 & $B b$ & 0,85 & $B b$ & $1,44 \quad \mathrm{~A} a$ \\
\hline $07 / 04$ & 0,62 & $C b$ & 0,90 & $B b$ & 1,04 & $A B a b$ & $1,21 \quad \mathrm{~A} a$ \\
\hline
\end{tabular}

Médias seguidas da mesma letra, maiúscula na linha e minúscula na coluna, nåo diferem significativamente entre si $(P>0,05)$ pelo teste de Tukey.

C.V. $(\%)^{(1)}=11,62$

C.V. $(\%)^{(2)}=20,08$ 
(a)

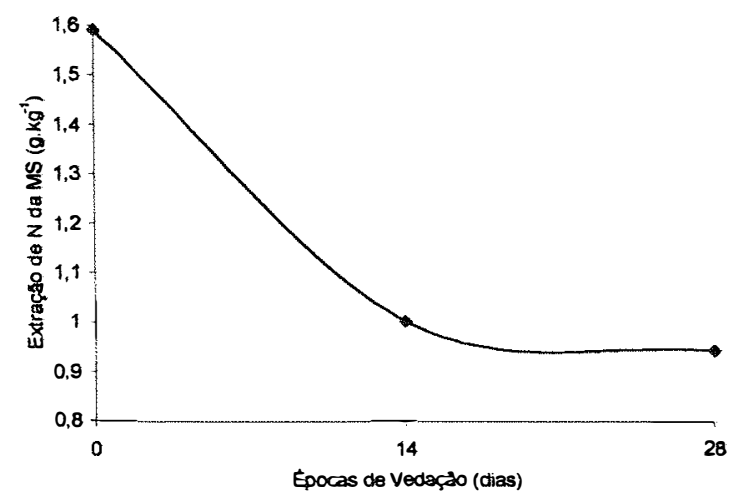

(b)

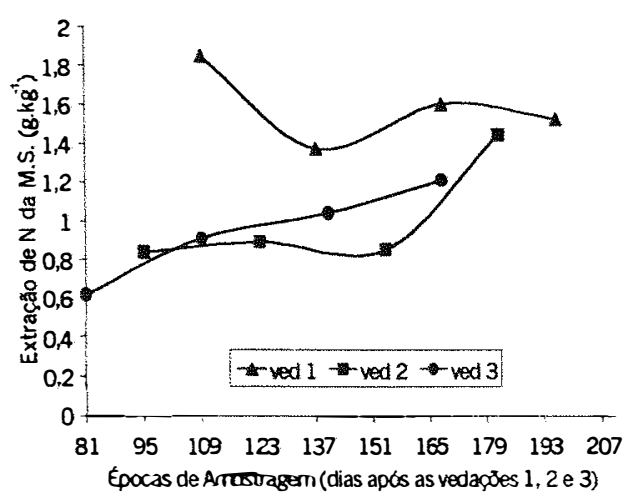

Figura 20. Extração de $\mathrm{N}$ na matéria seca $\left(\mathrm{g} \cdot \mathrm{kg}^{-1}\right)$ obtido da parte aérea do Panicum maximum cv. Mombaça, em função das épocas de vedação onde 0 corresponde a vedação realizada em 10/03/97, 14 corresponde a vedação realizada em 24/03/97 e 28 corresponde a vedação realizada em 07/04/97 (a) e dos períodos de uso avaliados - épocas de amostragem (junho, julho, agosto e setembro), em dias após as vedações 1 (10/03/97), 2 (24/03/97) e $3(07 / 04 / 97)(b)$.

Os demais nutrientes extraídos na matéria seca do Panicum maximum cv. Mombaça, $\mathrm{P}, \mathrm{Ca}$ e $\mathrm{S}$, apresentaram efeitos entre épocas de vedação, com maiores valores para a vedação em 10/03, (0,30 g.m $\mathrm{m}^{-2} ; 1,14$ g.m $\mathrm{m}^{-2}$ e 0,17 g.m $\mathrm{m}^{-2}$ ), respectivamente, sem diferenças estatísticas para as demais vedações (Quadro 2 e Figura 21). Para os períodos de uso, verificou-se que as maiores extrações foram nas respectivas utilizações de agosto e setembro, para os nutrientes $P\left(0,23 \mathrm{~g} \cdot \mathrm{m}^{-2}\right.$ e 0,23 g. $\left.\mathrm{m}^{-2}\right)$ e $\mathrm{Ca},\left(0,94 \mathrm{~g} \cdot \mathrm{m}^{-2}\right.$ e $\left.1,18 \mathrm{~g} \cdot \mathrm{m}^{-2}\right)$. O nutriente $S$ extraído na MS do Panicum não variou face às diferentes amostragens (Quadro 2). Considerando-se as Figuras $20 \mathrm{e}$ 21, constatou-se que as maiores extrações desses macronutrientes na MS da forrageira coincidiram com as maiores produções de MS, observada na primeira época de vedação (10/03), enquanto que para as outras duas épocas (24/03) e (07/04), foram observadas de maneira geral, menores produções e menor quantidade de nutrientes extraídos. 


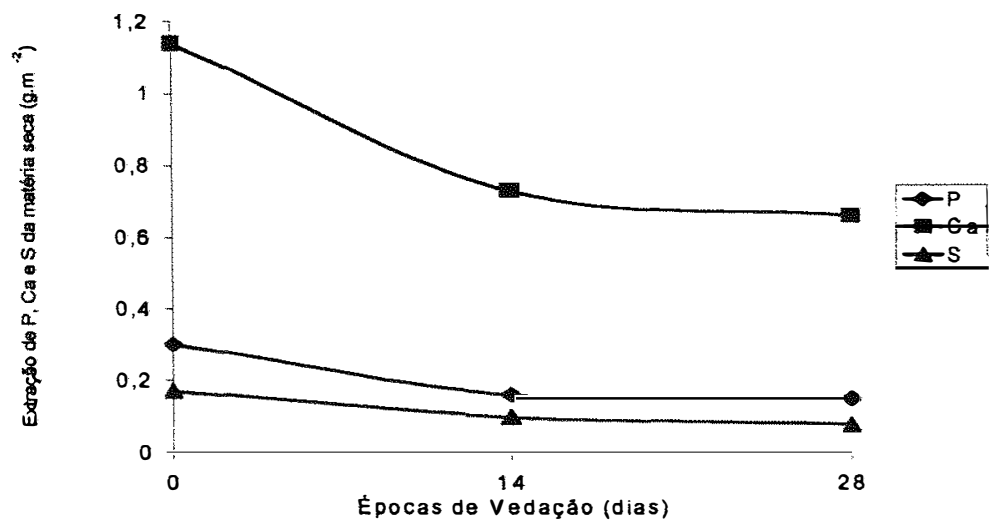

Figura 21. Teores de $\mathrm{P}, \mathrm{Ca}$ e $\mathrm{S}$ extraídos na matéria seca da parte aérea do Panicum maximum cv. Mombaça em função dos intervalos de vedação, onde 0 corresponde a vedação realizada em 10/03/97, o intervalo de 0 a 14 corresponde a vedação realizada em 24/03/97 e de 14 a 28 corresponde a vedação realizada em 07/04/97.

Ainda de acordo com o Quadro 2, verificou-se os efeitos das relações entre os nutrientes: N/S e Ca/P. Para a relação entre N/S, não foram reveladas diferenças significativas, em virtude das vedações e uso. Entretanto, para a relação Ca/P (Figura 22), foram encontradas diferenças significativas em função das utilizações, com média maior para valores encontrados em setembro, em tomo de 5/1 a 6/1, não diferindo de agosto de 3,5/1 a 5/1, com valores menores para o uso em junho (3/1 a 4/1) e julho (3,5/1 a 4/1). Todos os valores foram superiores aos relatados por Underwood (1971), cuja relação $1 / 1$ apresentou-se como a ideal. Wise et al. (1963), forneceram a bezerros dietas com relações $\mathrm{Ca} / \mathrm{P}$ variando de 0,4/1 a 14,3/1, e observaram desempenho satisfatório com relações entre 1/1 e 7/1, relatando que relações abaixo de 1/1 e acima de 7/1 diminuíram o crescimento e a eficiência da dieta. Baseando-se nesses últimos autores citados, os valores encontrados para a relação $\mathrm{Ca} / \mathrm{P}$, para o Panicum maximum cv. Mombaça estariam adequados. 


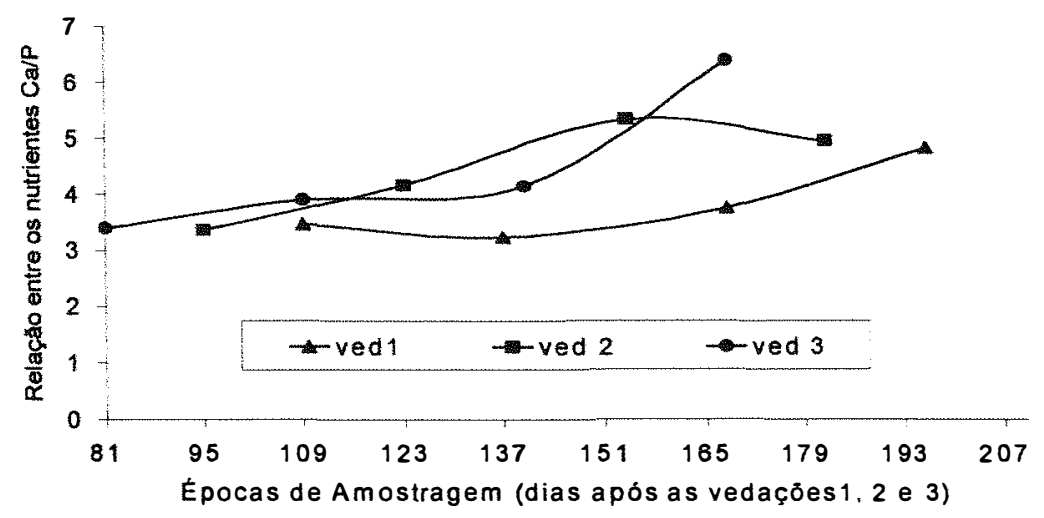

Figura 22. Relação entre os nutrientes Ca/P obtidos na parte aérea do Panicum maximum cv. Mombaça, em função e dos períodos de uso avaliados - épocas de amostragem (junho, julho, agosto e setembro), em dias após as vedações 1 (10/03/97), $2(24 / 03 / 97)$ e $3(07 / 04 / 97)$.

Segundo Boin (1985), a relação Ca/P passa a não ser importante quando são obtidos niveis adequados de $P$, os quais para o Panicum maximum cv. Mombaça mantiveram-se abaixo dos valores conferidos por Malavolta et al. (1986), (2,1 g. $\left.\mathrm{kg}^{-1}\right)$, independentemente das vedações e períodos de uso estudados. 


\section{CONCLUSŌES}

\subsection{Brachiaria brizantha cv. Marandu}

A produção de matéria seca, teores de FDN, FDA, lignina e DIVMS da Brachiaria brizantha cv. Marandu variam em função das épocas de vedação e periodos de uso.

As reduções na digestibilidade apresentadas foram afetadas principalmente pelos teores de lignina.

As épocas de vedação no final de março ou inicio de abril não apresentam-se adequadas para Brachiaria brizantha cv. Marandu com esse tipo de manejo de pastagens por apresentarem baixa produção em MS.

A extração dos nutrientes coincidiu com a máxima produção em MS; foram verificadas deficiências de $\mathrm{N}$ e P e baixa relação N/S.

Visando conciliar produção de matéria seca e valor nutritivo para a Brachiaria brizantha CV. Marandu, a vedação da pastagem no início de março, para uso no periodo seco preferencialmente em julho, apresenta-se mais promissora. 


\subsection{Panicum maximum cv. Mombaça}

A produção de matéria seca do Panicum maximum cv. Mombaça varia em função das épocas de vedação e períodos de amostragens.

Entre as épocas de vedação estudadas, não foram verificadas influências nas variáveis proteína bruta e digestibilidade, entretanto as vedações no final de março ou inicio de abril apresentam menores teores de fibra.

As reduções na digestibilidade apresentadas, foram afetadas principalmente pelos teores de lignina, com uso em junho.

A extração dos nutrientes coincidiu com a máxima produção em MS e foram verificadas deficiências de $\mathrm{N}$ e $\mathrm{P}$ e baixa relação N/S para o Panicum maximum cv. Mombaça.

Visando conciliar produção de matéria seca e valor nutritivo, verifica-se que vedar o pasto no final de março para uso no período seco, preferencialmente em agosto, apresenta melhores resultados. 


\section{REFERÊNCIAS BIBLIOGRÁFICAS}

ABAUNZA, M. A.; LASCANO, C. E.; GIRALDO, H.; et al. Valor nutritivo y aceitabilidad de gramineas y leguminosas forrajeras tropicales en suelos ácidos. Pasturas Tropicales, v.13, n.2, p. 2-9, ago. 1991.

ALCÂNTARA, V. B. G.; PEDREIRA, J. V. S.; MATTOS, H. B. et al. Medidas "in vitro" de valores nutritivos de capins. I. Produção e digestibilidade "in vitro" de vinte e cinco capins durante o outono e inverno. Boletim da Indústria Animal, v. 38, n. 2, p.155-176, jul./dez. 1981.

ANDRADE, I. F. Efeito da época de vedação na produção e valor nutritivo do capimelefante (Pennisetum purpureum, Schum) cv. Mineiro. Revista da Sociedade Brasileira de Zootecnia, v. 22, n. 1, p. 53-63, 1993.

ANDRADE, I. F.; AIRES, I. M.; BASTOS, C. M. C., et. al. Efeito da época de vedação sobre a produção e valor nutritivo do capim elefante (Pennisetum purpureum, Schum) cv. Cameroon. Revista da Sociedade Brasileira de Zootecnia, v. 19, n. 4, p. 243255, jul/ago. 1990.

ARROYO-AGUILÚ, J.A.; COWARD-LORD, J. Relationships between and within physical and chemical constituents and in vitro true digestibility in tropical forage grasses. Journal of Agriculture of University of Puerto Rico, v.58, n.4, p.437447, Oct. 1974.

ASSOCIATION OFFICIAL ANALYTICAL CHEMISTS. Official methods of analysis. 16.ed. Washington: AOAC, 1995. $2 \mathrm{v}$. 
BARBOSA, C. L.; MONKS, P. L.; CENTENO, G. A. Produção e qualidade da forragem do capim elefante (Pennisetum purpureum Schum) cv. Vruckwona submetido a diferentes épocas de diferimento e cortes. Ciência Rural, v. 25, n. 1, p.115-119, jan./abril. 1995.

BATAGLIA, O.C. Determinação indireta de enxofre em plantas por espectrofotometria de absorção atômica. Ciência e Cultura, v.28, n.6, p.672-5, jun. 1976.

BOIN, C. Exigências de minerais pelas categorias do rebanho bovino e funções desses nutrientes. In: SIMPÓSIO SOBRE NUTRIÇÃO DE BOVINOS, 3., Piracicaba, 1985. Anais. Piracicaba: FEALQ, 1985. p.15-46.

BURTON, G. W.; JACKSON, J. E.; KNOX, F. E. The influence of light reduction upon the production, persistence, and chemical composition of Coastal Bermudagrass, Cynodon dactylon. Agronomy Journal, Madison, v. 51, p. 537-42, 1959

BUXTON, D.R.; REDFEARN, D.D. Plant limitations to fiber digestion and utilization. Journal of Nutrition, v.127, Suppl. 5S, p.814-818, 1997.

CHURCH, D.C. El ruminante: fisiologia digestiva y nutricion. Zaragoza: Editorial ACRIBIA, 1993. 641p.

CORSI, M. Adubação nitrogenada em pastagens. In: PEIXOTO, A M. (Ed.) Pastagens: fundamentos da exploração racional. 2. ed. Piracicaba: FEALQ, 1994. p. 121-154.

COSTA, N. L. de. Efeito do diferimento sobre a produção e composição química de gramineas forrageiras tropicais. Porto Velho: EMBRAPA-UEPAE, 1984. 5p. (EMBRAPA-UEPAE- Comunicado Técnico, 84).

COSTA, J. L.; CAMPOS, J.; GARCIA, R. et. al. Efeito da época de vedação sobre o valor nutritivo de capim-gordura (Melinis minutiflora Paul de Beauv) como pasto de reserva para o periodo da seca. Revista da Sociedade Brasileira de Zootecnia, v. 10, n. 4 , p. $765-783,1981$. 
COSTA, N. L. de; GONÇALVES, C. A.; OLIVEIRA, J. R., et . al. Rendimento de gramíneas forrageiras em Ariquemes- RO. Porto Velho: EMBRAPA,UEPAE, 1988. 4 p. (EMBRAPA. UEPAE. Comunicado Técnico, 63).

COSTA, N. L. de; OLIVEIRA, J. R. C. da; GONÇALVES, C.A. Introdução e avaliação de leguminosas forrageiras nos cerrados de Rondônia. Porto Velho: EMBRAPA, UEPAE, 1989. 5p. (EMBRAPA. UEPAE. Comunicado Técnico, 68).

COSTA, N. L. de; OLIVEIRA, J. R. C. da; PAULINO, V. T. Efeito do diferimento sobre o rendimento de forragem e composição química de Brachiaria brizantha cv. Marandu em Rondônia. Revista da Sociedade Brasileira de Zootecnia, v. 22, n. 1, p. 495-501, 1993.

DEINUM, B.; DIRVEN, J. G. P. Climate, nitrogen and grass. 7. Comparison of production and chemical composition of Brachiaria nuziziensis and Setaria sphacelata grown at different temperatures. Netherlands Journal of Agric. Science, v.24, n. 1, p. 67-78, 1976.

EASTRIDGE, M. L. Fibra para vacas leiteiras. In: SIMPÓSIO SOBRE PRODUÇÃO ANIMAL, 9. Piracicaba, 1997. Anais. Piracicaba: FEALQ, 1997. p 33-50.

EMPRESA BRASILEIRA DE PESQUISA AGROPECUÁRIA. Centro Nacional de Pesquisa Agropecuária de Gado de Corte. Relatório Técnico Anual 1982-1983. Campo Grande, 1983.

EUCLIDES, V. P. B.; MACEDO, M. C. M.; OLIVEIRA, M. P. de. Avaliação de ecotipos de Panicum maximum sob pastejo em pequenas parcelas. In: REUNIÃO ANUAL DA SOCIEDADE BRASILEIRA DE ZOOTECNIA, 32., Brasilia, 1995. Anais. Brasilia: SBZ, 1995. p.97-99.

EUCLIDES, V. P. B.; VALLE, C. B. do; SILVA, J. M. da. et al. Avaliação de forrageiras tropicais manejadas para produção de feno-em-pé. Pesquisa Agropecuária Brasileira, v. 25, n. 3, p. 393-407, 1990.

FALES, S. L. Effects of temperature on fiber concentration, composition, and in vitro digestion kinetics of tall fescue. Agronomy Journal, v.78, p. 963-966, 1986. 
FICK, K.R.; MCDOWELL, L.R.; HOUSER, R.H. Current status of mineral research in Latin America. In: LATIN AMERICAN SYMPOSIUM ON MINERAL NUTRITION RESEARCH WITH GRAZING RUMINANTS, Belo Horizonte, 1976. Proceedings. Gainesville: University of Florida, 1978. p.149-162.

FLEMING, G.A. Mineral composition of herbage. In: BUTLER, G.W.; BAILEY, R.W. Chemistry and biochemistry of herbage. New York: Academic Press, 1973. v.1, p.529-566.

FOLLETT, R.F.; WILKINSON, S.R. Nutrient management of forages. In: BARNES, R.F.; MILLER, D.A.; NELSON, C.J. Forages: the science of grassland agriculture. 5.ed. Ames: lowa State University Press, 1995. v.2, p.55-82.

FONTANELI, R. S.; JACQUES, A. V. A.; HENRICH, C., et. al. Efeito da ceifa, da queima, do diferimento e da adubação sobre uma pastagem natural. Revista da Sociedade Brasileira de Zootecnia, v. 23, n. 5, p. 719-729, set./out. 1994.

FORBES, J.M. Voluntary food intake and diet selection in farm animals. Wallingford: CAB International, 1995. 532p.

FORD, C. W.; MORRISON, I. M.; WILSON, J. R. Temperature effects on lignin, hemicellulose and cellulose in tropical and temperate grasses. Australian Journal Agricultural Research, v. 30, p. 621-633, 1979.

GALLO, J.R.; HIROCE, R.; BATAGLIA, O.C. et al. Composição química inorgânica de forrageiras do Estado de São Paulo. Boletim da Indústria Animal, v.31, n.1, p.115-137, jan./jun. 1974.

GOERING, H.K.; VAN SOEST, P.J. Forage fiber analysis: apparatus, reagents, procedures and some applications. Washington: USDA, 1970. 20p. (USDA. Agriculture Handbook, 379).

GOMIDE, J.A. Mineral composition of grasses and tropical leguminous forages. In: LATIN AMERICAN SYMPOSIUM ON MINERAL NUTRITION RESEARCH WITH GRAZING RUMINANTS, Belo Horizonte, 1976. Proceedings. Gainesville: University of Florida, 1978. p.32-40. 
GUZMÁN, L. P.; RICCI, H. R.; JUÁREZ, V. P. Efecto de diferir el corte en la producción invernal de gramíneas tropicales. Pasturas Tropicales, v. 16, n. 1, p.2226, abr. 1994.

HODGSON, J. Grazing management-science into Practice. New York: John Wiley, 1990. 203p.

JANK, L. Melhoramento e seleção de variedades de Panicum maximum. In: SIMPÓSIO SOBRE MANEJO DA PASTAGEM, 12, Piracicaba, 1995. Anais Piracicaba: Fealq, 1995. p. 21-58.

JANK, L.; COSTA, J. C. G. Avaliação, seleção e lançamentos de novas cultivares de gramíneas da espécie Panicum maximum. In: ENCONTRO SOBRE PRODUÇÃO DE SEMENTES DE PLANTAS FORRAGEIRAS, 4., São José do Rio Preto, 1990. Anais. São José do Rio Preto: Associação Paulista dos Produtores de Sementes e Mudas, 1990. p. 1-15.

JANK, L.; COSTA, J. C. G.; SAVIDAN, Y. H. et al. New Panicum maximum cultivars for diverse ecosystems in Brazil. In: INTERNATIONAL GRASSLAND CONGRESS, 17., Palmerston North, 1993. Proceedings.. Palmerston North: New Zealand Grassland Association, 1993. p. 509-511.

JANK, L.; SAVIDAN, Y. N.; SOUZA, M. T. de; et al. Avaliação do germoplasma de Panicum maximum introduzido da África. I. Produção forrageira. Revista da Sociedade Brasileira de Zootecnia, v. 23, n. 3, p. 433-440, 1994.

LITTLE, D.A Utilization of minerals. In: HACKER, J.B., Ed. Nutritional limits to animal production from pastures. Farnham Royal: Commonwealth Agricultural Bureaux, , 1982. p.259-283.

MALAVOLTA, E.; LIEM, T.H; PRIMAVESI, A.C.P.A. Exigências nutricionais das plantas forrageiras. In: MATTOS, H.B. Ed. Calagem e adubação de pastagens. Piracicaba: Associação Brasileira para Pesquisa da Potassa e do Fosfato, 1986 p.31-91. 
MILFORD, R. HAYDOCK, K. P. The nutritive value of protein in subtropical pasture species grown in south-east Queensland. Austr. J. Exp. Agric. Anim. Husb., v. 5, n. 1, p. 13-17, 1965.

MINSON, D.J. Composición química y valor nutritivo de las gramíneas tropicales. In: SKERMAN, P.J.; RIVEROS, F. Gramíneas tropicales. Roma: FAO, 1992. p.18199. (Colección FAO: Producción Vegetal, 23).

MINSON, D.J. Forage in ruminant nutrition. San Diego: Academic Press, 1990. $483 p$.

MINSON, D.J. The nutritive value of tropical pastures. Austr. J. Exp. Agric. Anim. Husb., Victoria, v. 37, 1971, p. 255263.

MOLINA, J.; FARIA-MÁRMOL, J.; CHIRINOS, Z. Efecto de diferir la época de utilización en la producción y calidad de la associación Panicum maximum-Leucena leucocephala. Pasturas Tropicales, v. 18, n.1, p. 51-54, abr. 1996.

MONTEIRO, F. A Nutrição mineral e adubação. In: SIMPÓSIO SOBRE MANEJO DA PASTAGEM, 12, Piracicaba, 1995. Anais. Piracicaba: FEALQ, 1995. p. 219-244.

MOORE, J.E.; MOTT, G.O. Structural inhibitors of quality in tropical grasses. In: MATCHES, A.G. Anti-quality components of forages. Madison: CSSA, 1973. p.53-98. (Special Publication, 4).

NORTON, B.W. Differences between species in forage quality. In: HACKER, J.B., ed. Nutritional limits to animal production from pastures.: Farnham Royal, Commonwealth Agricultual Bureaux, 1982. p.89-110.

NUNES, S. G.; BOOCK, A.; PENTEADO, M. I. de O.; GOMES, D. T. Brachiaria brizantha cv. Marandu. Campo Grande: EMBRAPA, CNPGC, 1985. (EMBRAPA. CNPGC. Documentos, 21)

OMALIKO, C. P. Stockpiling of three tropical forage grasses species. Agronomy Journal., v. 75, n. 4, p. 677-679, 1983. 
PAULINO, V. T.; BEISMAN, D. A.; FERRARI, Jr., E. Fontes de nitrogênio na recuperação de pastagens de Brachiaria decumbens durante o período da seca. Pasturas Tropicales, v.17, n. 2, p.20-24,1995.

PEDREIRA, C.G.S. Plant and animal responses on grazed pastures of Florakirk and Tifton 85 bermudagrasses. Florida, 1995. 152p. Thesis (Ph.D) - University of Florida.

PEDREIRA, J. V. S. Crescimento estacional dos capins colonião (Panicum maximum Jacq.), Gordura (Melinis minutiflora Pal de Beauv.), Jaraguá (Hyparhenia rufa (ness) Stapf) e pangola de Taiwan A-24 (Digitaria pentzii, Stent). Boletim da Indústria Animal, Nova Odessa, SP, v. 30, n. 1, p. 59-145, jan.jun. 1973.

PIZARRO, E. A.; AMARAL, R.; VERA, R. R. Efecto de diferir la época de utilización y calidad de Panicum maximum. Pasturas Tropicales, v. 15, n. 1, p.23-29, abr. 1993.

PIZARRO, E. A.; VERA, R. R. Efecto de diferir la época de utilización en la producción y calidad de Centrosema pubescens. Pasturas Tropicales, v. 12, n. 1, p.39-43, 1997.

QUESENBERRY, K. H.; OCUMPAUGH, W. R. Mineral composition of autumn-winter stockpiled limpograss. Tropical Agriculturist., Trinidad, v. 59, n. 4, p. 283-286, 1982.

REID, R.L.; JUNG, G.A. Effects of elements other than nitrogen on the nutritive value of forage. In: MAYS, D.A., Ed. Forage fertilization. Madison: ASA, CSSA, SSSA, 1974. p.395-433.

ROBINSON, D.L. Fertilization and nutrient utilization in harvested forage systems Southern forage crops. In: NUTRIENT CYCLING IN FORAGE SYSTEMS SYNPOSIUM, Columbia, 1996. Proceedings. Kansas: Potash and Phosphate Institute, Foundation for Agronomic research, 1996. p.65-92.

RODRIGUES, L. R. A;.REIS, R. Bases para o estabelecimento do manejo de capins do gênero Panicum. In: SIMPÓSIO SOBRE MANEJO DA PASTAGEM, 12 , Piracicaba, 1995. Anais. Piracicaba: Fealq, 1995, p. 197-217. 
SAS INSTITUTE. User's guide: statistics. release 6.03. Cary: SAS Institute, 1988. $1028 p$.

SENANAYAKE, S. G. J. N. The effects of different light levels on the nutritive quality of four natural tropical grasses. Tropical Grasslands, v.29, p. 111-114, 1995.

SILVA, J. H. S. da ; JOHNSON, W. L.; BURNS, J. C.; et al. Growth and enviroment effects on anatomy and quality of temperate and subtropical forage grasses. Crop Science, v. 27, p. 1266-1273, Nov./Dec. 1987.

SILVA, S. C. Condições edafo-climáticas para a produção de Panicum sp. In: SIMPÓSIO SOBRE MANEJO DA PASTAGEM, 12, Piracicaba, 1995. Anais. Piracicaba: FEALQ, 1995. p. 129-146.

SOTOMAYOR-RÍOS, A.; JULIÁ, F.J.; ARROYO-AGUILÚ, J.A. Effects of harvest intervals on the yield and composition of 10 forage grasses. Journal of Agriculture of University of Puerto Rico, v.58, n.4, p.448-455, Oct. 1974.

TILLEY, J. M. A.; TERRY, R. A. A two stage tecnique for the "in vitro" digestion of forage crops. Journal of British Grassland Society., v. 18, n. 2, p. 104-111, 1963.

TINNIMIT, P. Forage evaluation using various laboratory techniques. East Lansing, 1974. Thesis (Ph.D.) - Michigan State University.

UNDERWOOD, E.J. Trace elements in human and animal nutrition. 3.ed. New York: Academic Press, 1971. 543p.

VALLE, C. B. do; MOORE, K. J.; MILLER, D.A. Cell wall composition and digestibility in five species of Brachiaria. Tropical Agriculture, v.65, n.4, p.337-340, Oct. 1988.

VAN SOEST, P.J. Nutritional ecology of the ruminant. 2.ed. New York: Comell University Press, 1994. 476p.

VITTI, G.C.; NOVAES, N.J. Adubação com enxofre. In: MATTOS, H.B. Ed. Calagem e adubação de pastagens. Piracicaba: Associação Brasileira para Pesquisa da Potassa e do Fosfato, 1986. p.191-231. 
WAN HASSAN, W. E.; PHIPPIS, R. H.; OWEN, E. Dry matter yield and nutritive value of improved pasture species in Malaysia. Tropical Agriculture, v.67, n.4, p.303308, Oct. 1990.

WERNER, J. C. Adubação de pastagens. Nova Odessa: Instituto de Zootecnia de Nova Odessa, 1984. (Boletim Técnico, 18).

WILSON, J. R. Effects of water stress on in vitro dry matter digestibility and chemical composition of herbage of tropical pasture species. Australian Journal Agricultural Research, v. 34, p. 377-390, 1983.

WILSON, J. R.; Ng, T. T. Influence of water stress on parameters associated with herbage quality of Panicum maximum var. trichoglume. Australian Journal Agricultural Research, v. 26, p. 127-136, 1975.

WILSON, J. R.; DEINUM, B.; ENGELS, F. M. Temperature effects on anatomy and digestibility of leaf and stem of tropical and temperate forage species. Netherlands Journal of Agricultural Science, v.39, n. 1, p. 31-48, Mar 1991.

WILSON, J. R.; TAYLOR, A O.; DOLBY, G. R. Temperature and atmosferic humidity effects on cell wall content and dry matter digestibility of some tropical and temperate grasses. New Zealand. Journal of Agriculture Research., v.19, n. 1, p. 41-46, feb. 1976.

WISE, M.B.; ORDOREZA, A.L.; BARRICK, E.R. Influence of variations in dietary calcium:phosphorus ratio on performance and blood constituents of calves. Journal of Nutrition, v.79, n.1, p.79-85, Jan. 1963. 